\title{
فاعلية استخدام إستراتيمية الأبعاد السداسية (PDEODE) في تدريس الاقتصاد المنزلي علي تنمية المفاهيم الصهية والسلوكيات الاقتصادية لدي طالبات الصف الأول الثانوي
}

\author{
إعداد \\ ه / غادة " محمد حسنحــ " النوبحسـ محمد \\ مدرس مناهج وطرق تدريس الاقتصاد المنزبي

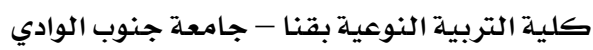

مجلة بحوث التربية النوعية ـ جامعة المنصورة

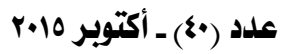




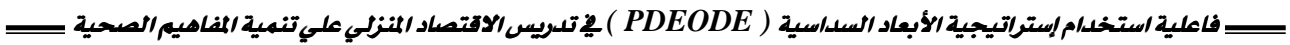




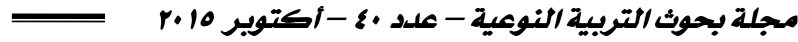

\section{فاعلية استخدام إستراتيمية الأبعاد السداسية (PDEODE)}

\section{في تدريس الاقتصاد المنزبلي علي تنمية الافاهيم الصهية}

والسلوكيات الاتتصادية لدي طالبات الصف الأول الثانوي

إعداد

د / غادة" محمد حسني "النوبيمحمد

هذص البحث:

هـدفت الدراسـة الحاليـة إلي التعـرف علسي فاعليـة إسـتخدام اسـتراتيجية الأبعـاد السـداسية

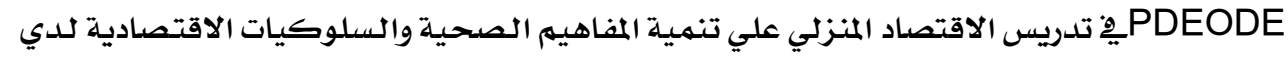

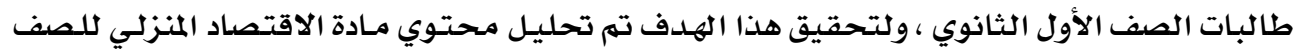

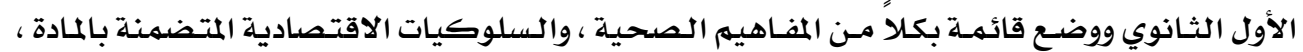

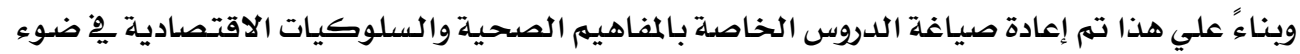

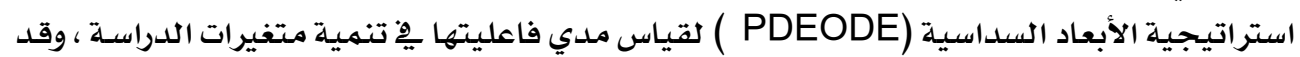

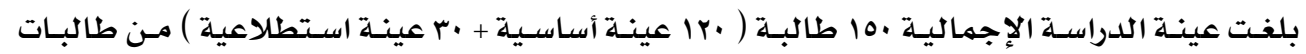

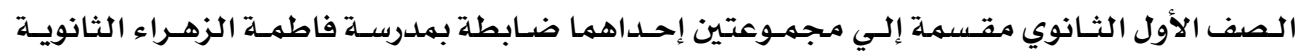

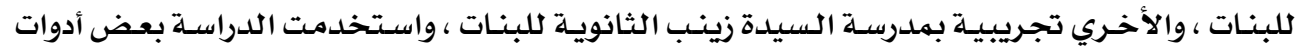

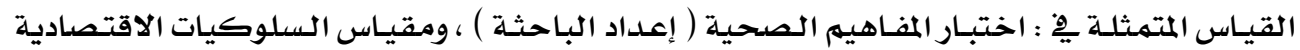

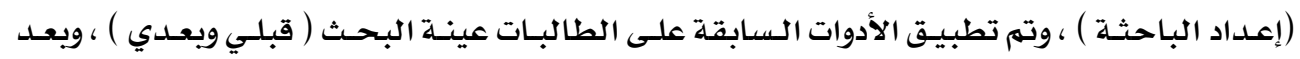

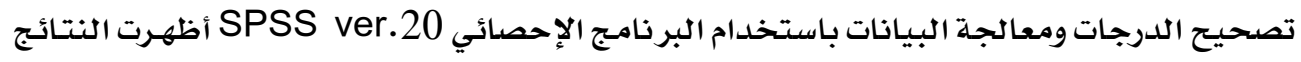
ما يلي : تصديت

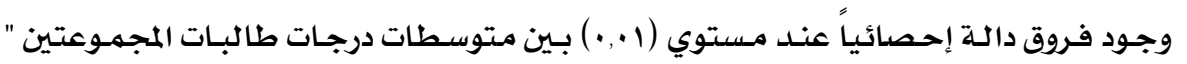

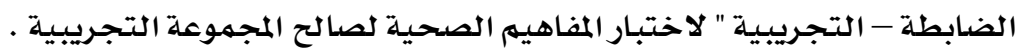

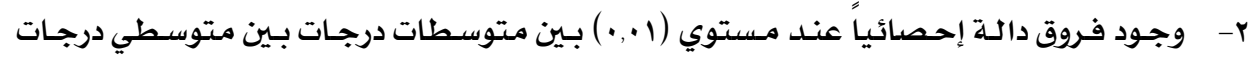

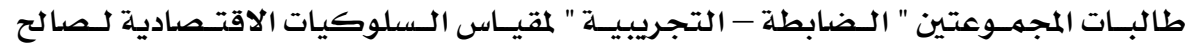

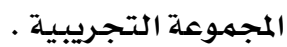
وِِّوء ضوالنتائج السابقة تم تقديم مجموعة من التوصيات والدراسات المقترحة .

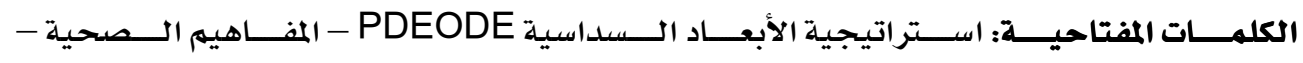
السلوكيات الاقتصادية .

مدرس مناهج وطرق تدريس الاقتصاد المنزلي - كلية التربية النوعية بقنا - جامعة جنوب الوادي 
تمثل المرحلة الثانوية قمة الهرم ِِّ التعليم العام قبل الجامعي فهي تهدف إلي تبصير

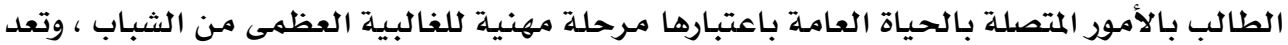

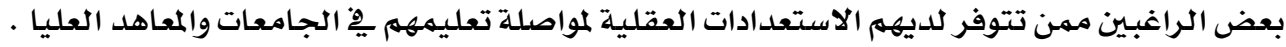

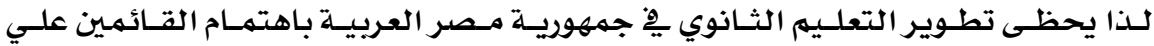

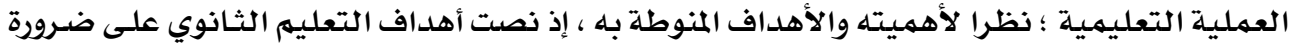

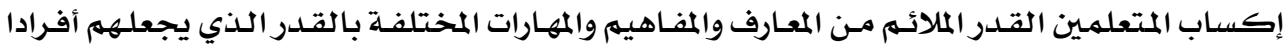

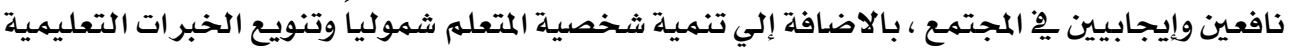

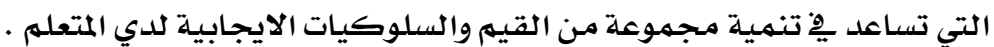

وِِِ ظل التغيرات التكنولوجية والاقتصادية التي تجتاح العالم بسرعة كبيرة ، ومـا لها مـن

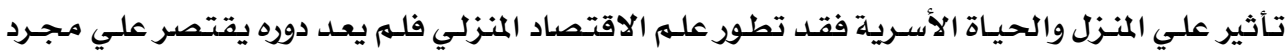

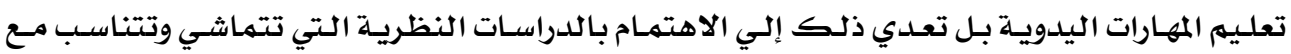

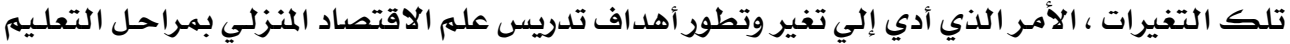

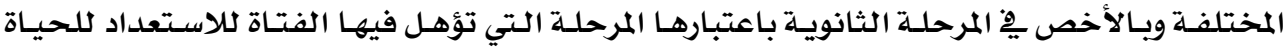

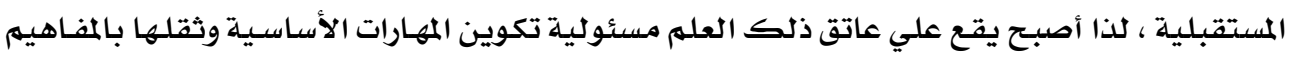

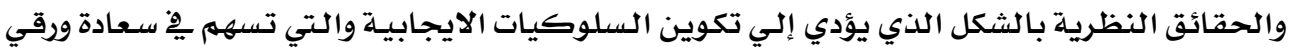

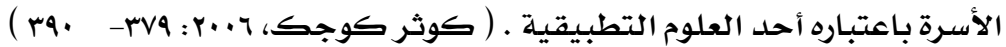

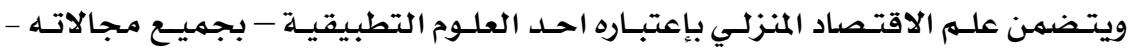

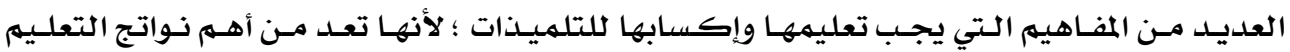

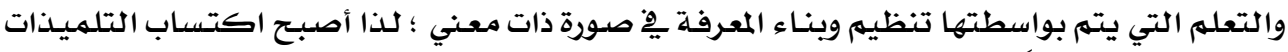

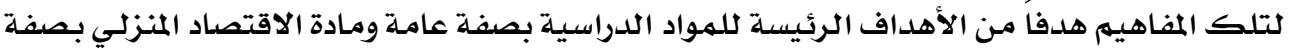

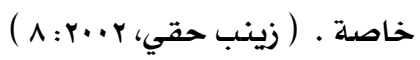

وتعتبر المفـاهيه الـصحية مـن المفـاهيه الـتي تسعي مـادة الاقتصـاد المنزلـي إلـي إكسـابها

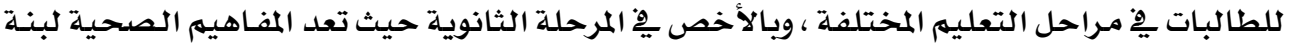

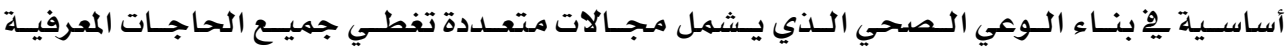

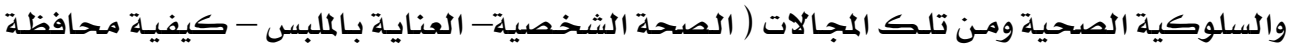

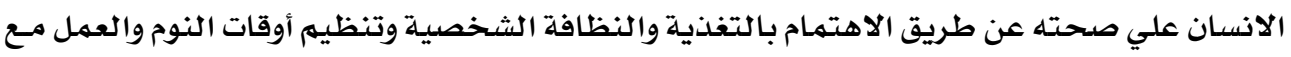

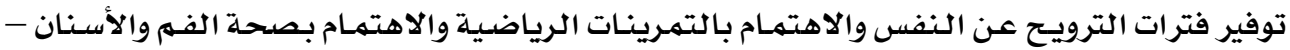

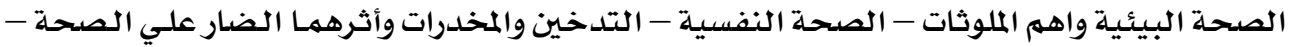

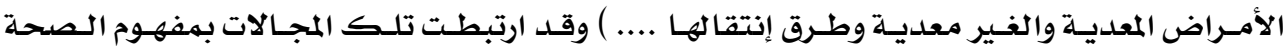

( Tan, et. Al, 2013 ). Hygiene 


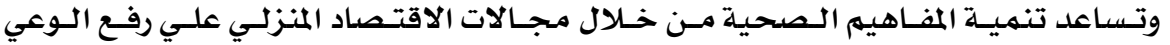

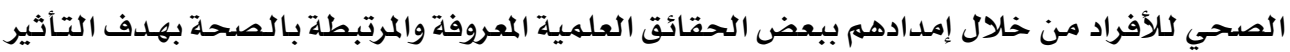

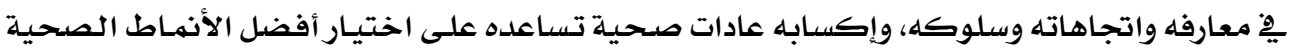

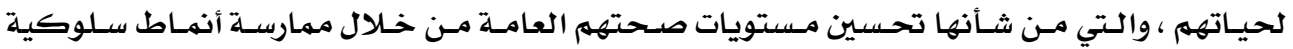

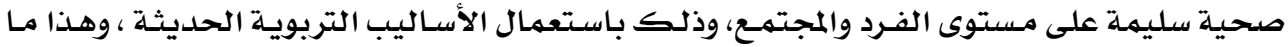

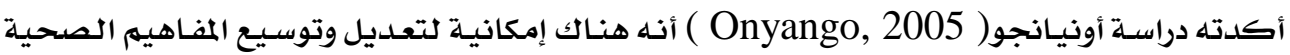

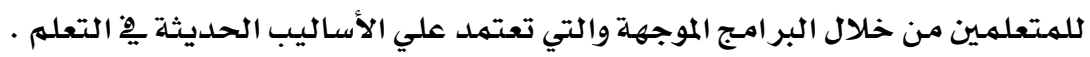

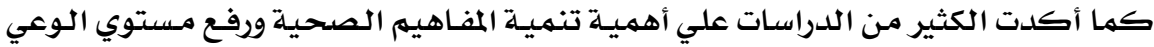

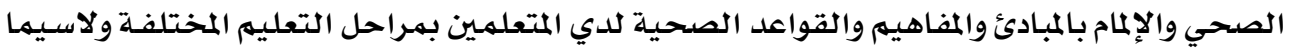

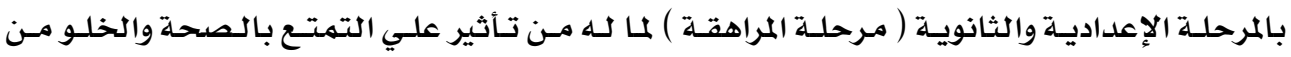

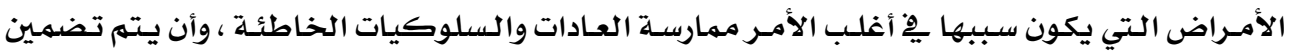

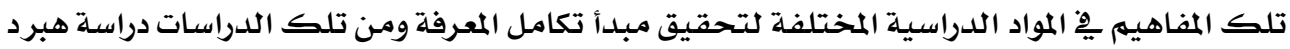

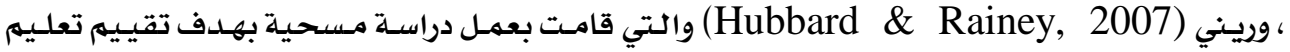

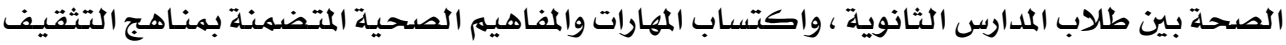

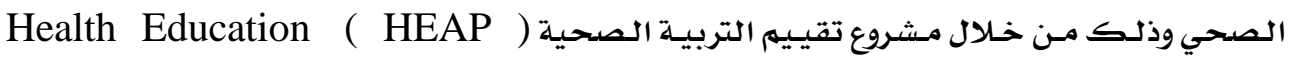
Assessment Project

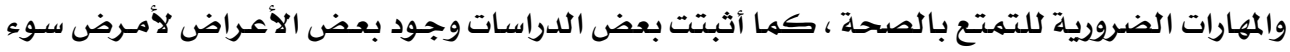

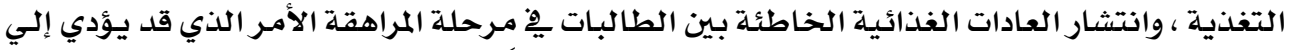

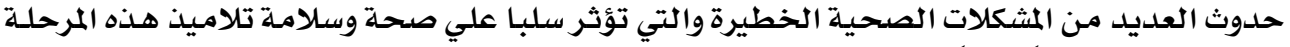

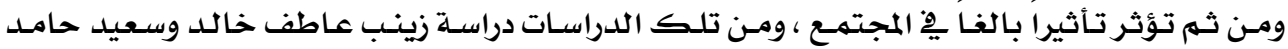

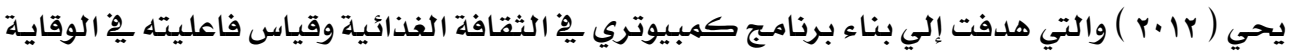

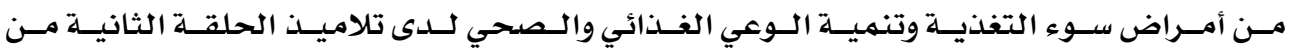

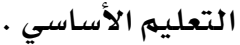

كما أصبحت ممارسة السلوكيات الاقتصادية Economic Behaviors مِّ العصر

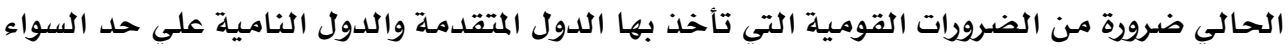

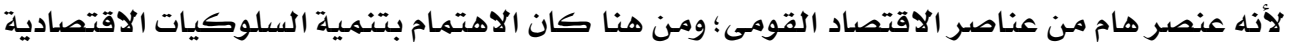

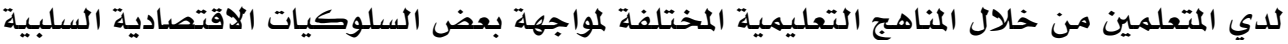

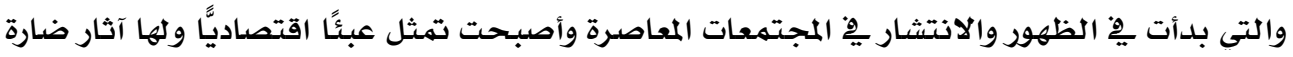

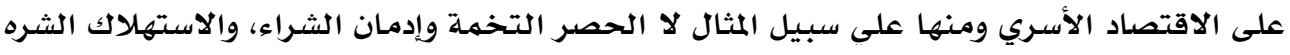

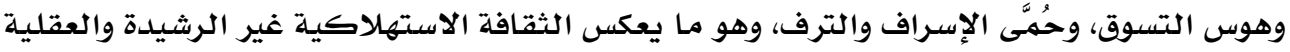
الاستهلاكية المسرفة، وتظهر تلك السلوكيات بالأخص فِّ مرحلة المراهقة وهو ما أكسته دراسلة

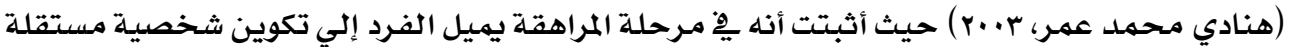




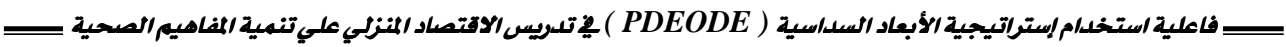
يحلدد فيها لنفسه سلوكاً معينا، لذا تزداد احتياجاته وطموحاته رغبة ِِّ التميز والظهور بين أقرانه،

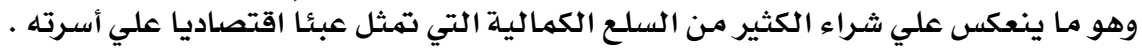

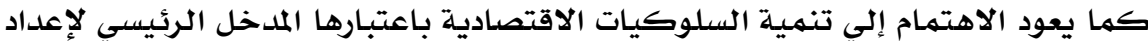

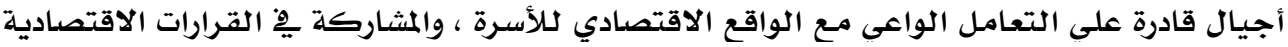

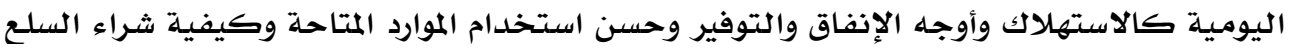

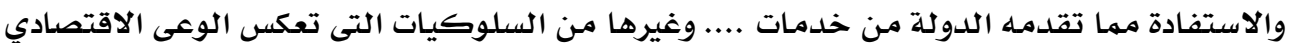

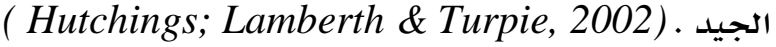

ومن خلال مجالات علم الاقتصاد المنزلي يمكن تنمية المفاهيهم الصحية والسلوكيات

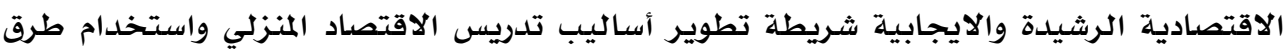

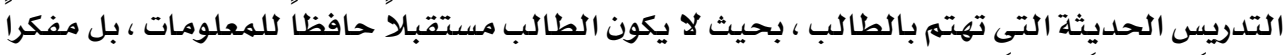

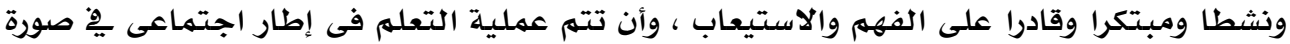

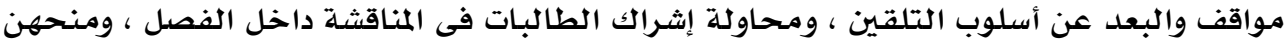

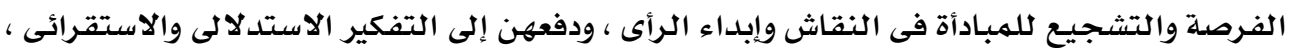

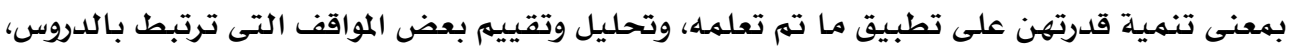

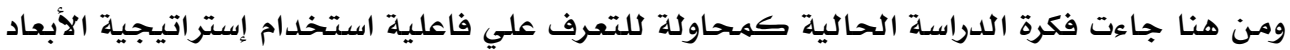

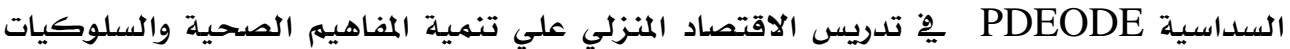
الاقتصادية لدي طالبات الصف الأول الثانوي .

\section{الإحساس بمشكلة الدراسة لاسلة لالية}

لقد نبع الإحساس بمشكلة الدراسة الحالية من خلال :-

ا ـ ملاحظة الباحثة - أثناء قيامها بالزيارات الميدانيـة للمـدارس الثانويـة للبنـات - بعض حسالات

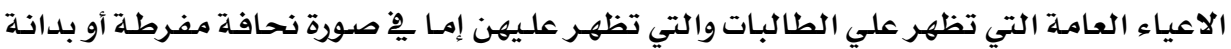

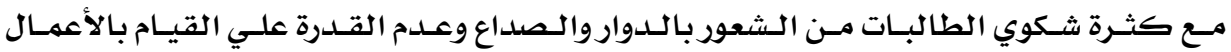

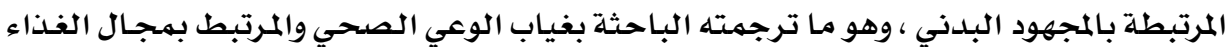

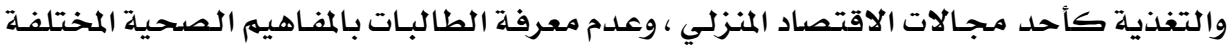

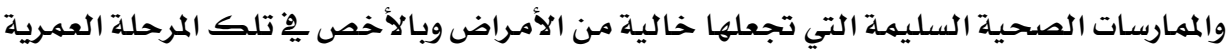
، وهو ما يترتب عليه شعورها بحاله الضعف العام والهات العاعياء. r. قيام الباحثة بعمل دراسة استطلاعية اعتمدت علي المقابلة الشخصية مـع مجموعة من الطالبات

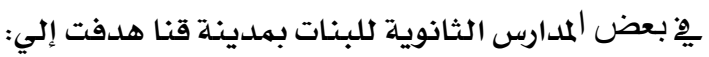

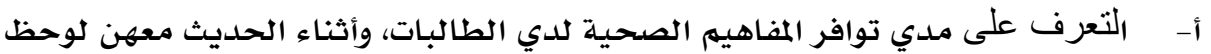

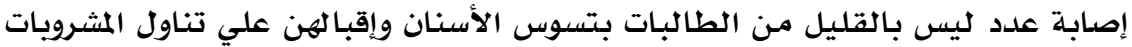
الغازية الضارة بالصحة وعد الاهتمام بتناول وجبة الإفطار والاستغناء عنها بتناول 


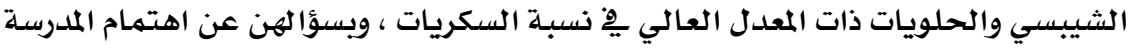

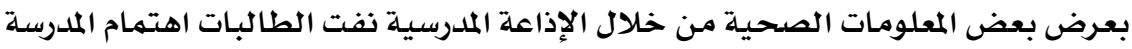

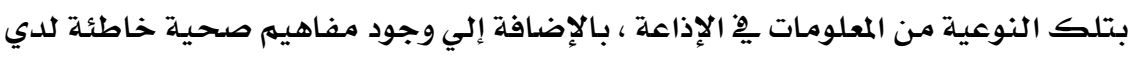

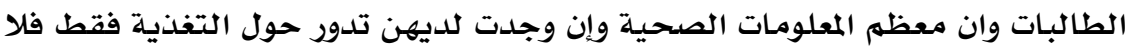

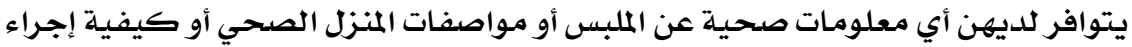

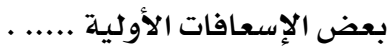

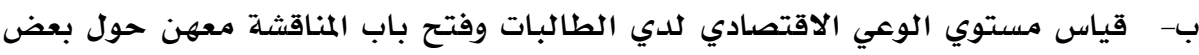

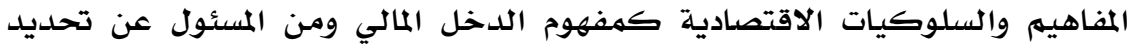

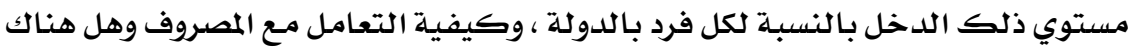

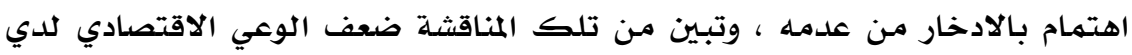

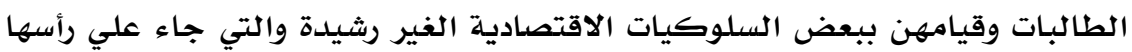

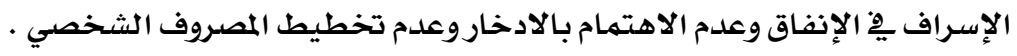

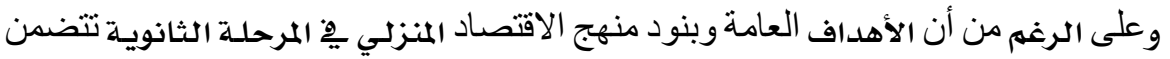

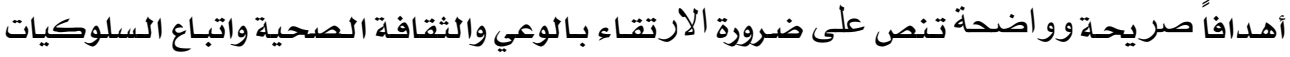

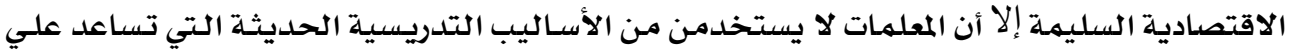

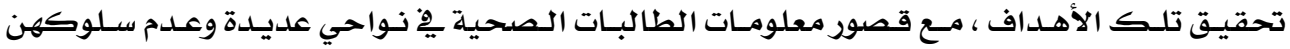

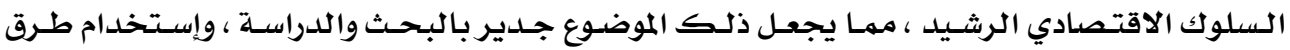

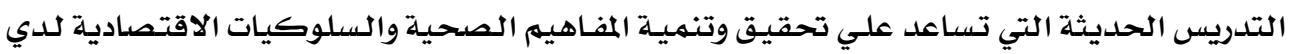

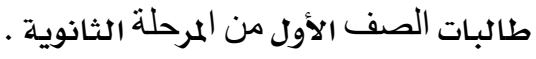

\section{تهديد هشكلة الدراسة}

تعد مادة الاقتصاد المنزلي أحد فروع العلهم التطبيقية ، ومن المواد الدراسية التي لها علاقة

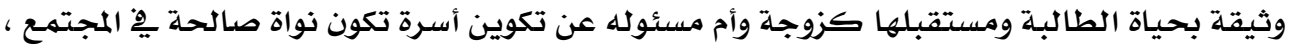

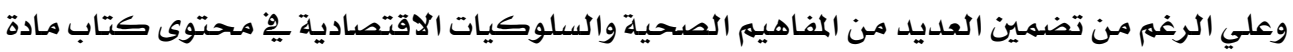

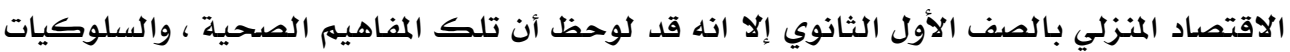

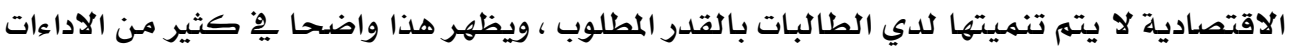

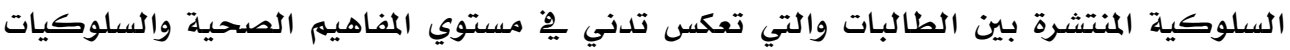
الاقتصادية لديهن ، وقد يرجع ذالك إلي قصور استراتيجيات التدريس التقليدية التئية التي تتبعها معلمهـ

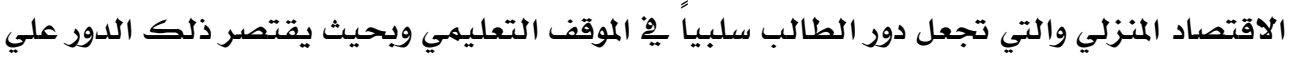

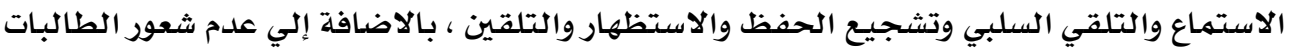

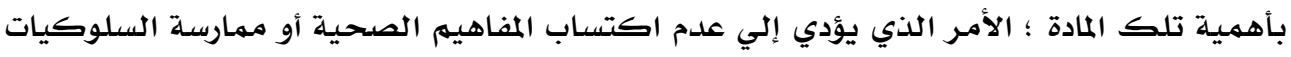

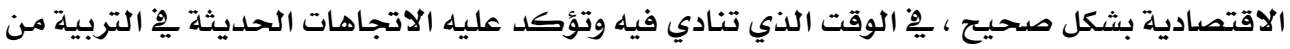

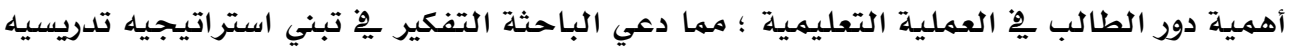




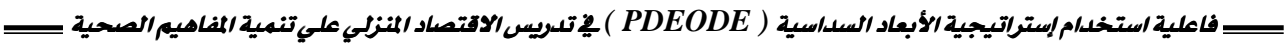

حديثة تساعد ِِّ تحقيق الأهداف التربوية لمادة الاقتصاد المنزلي وتجعل الطالب المحور الرئيسي فِ

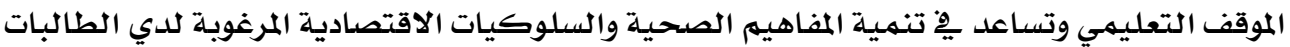
لذلك تسعي الدراسة الحالية إلي استخدام استراتيجيه الأبعاد السداسية

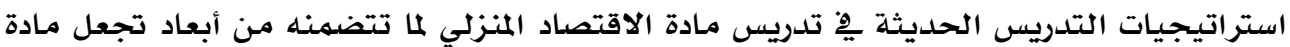

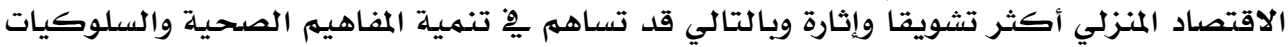
الاقتصادية لدي طالبات الصف الأول الثانوي التصني

وِوِ حدود علم الباحثة لا توجد دراسلة عربية تناولت استراتيجية الأبعاد السداسية

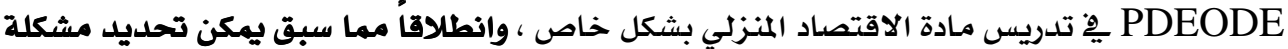
الدراسة الحالية بِ السؤال الرئيسي التالي: " ما فاعلية إستخدام استراتيجية الأبعاد السداسية PDEODE هِْ تدريس الاقتصاد

المنزلي علي تنمية المفاهيم الصحية والسلوكيات الاقتصادية لدي طالبـات الصف الأول الثانوي " ؟

$$
\text { وانبثق من السؤال الرئيس السابق السؤلان الفرعيان الآتيان: }
$$

ا- ما فاعلية استخدام استراتيجية الأبعاد السداسية PDEODE مِّْ تدريس الاقتصاد المنزلي

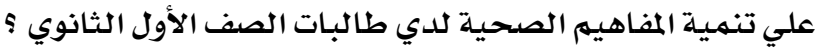

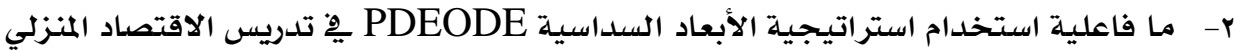

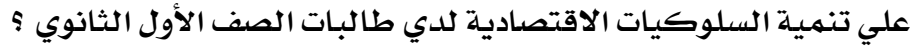

أهميهة الدراسة علي تنية

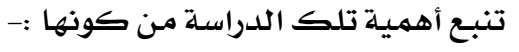

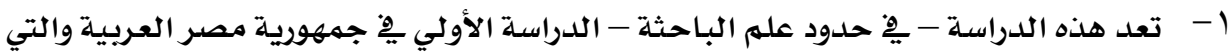

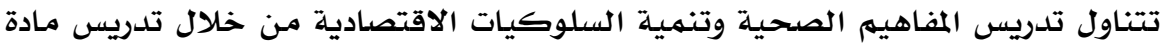

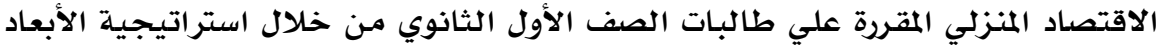

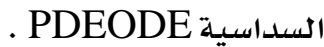

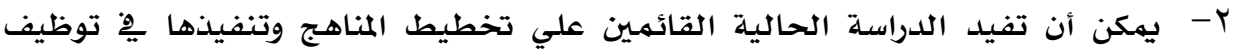

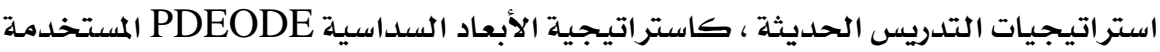

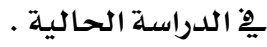

ץ- تقديم قائمة بالمفاهيم الصحية وقائمة أخري بالسلوكيات الاقتصادية التي يمكن تنميتها

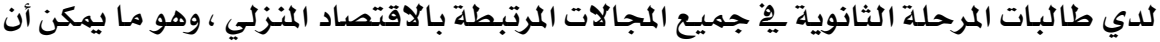

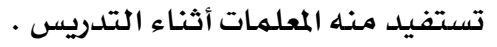

؟ - توعية الطالبات وبالأخص مِّه مـرحلة المراهقة بالسلوكيات الاقتصادية الرشيدة وكيفية

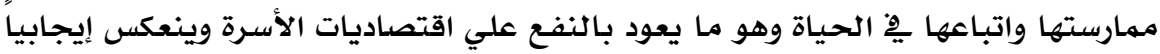




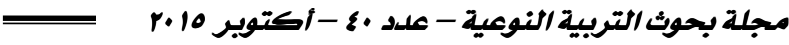

0- تضيف الدراسة للباحثين ِِّ مجال التخصص إطاراً نظرياً يتمثل ِِّ إستراتيجية الابعاد

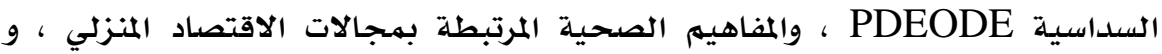

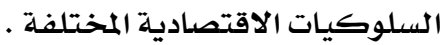

هدفا الدراسة

هدفت الدراسة الحالية إلى التعرف على :

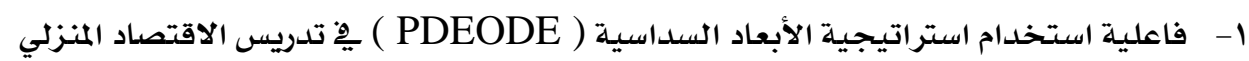

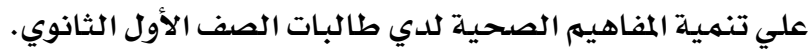

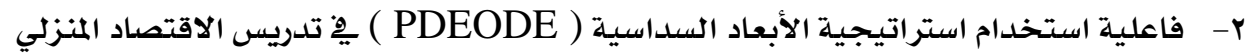

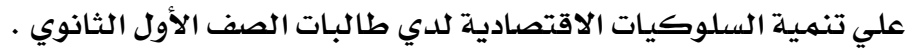

\section{التعريفات الإجرائية الصطات الدات الدراسة :}

\section{PDEODE Teaching Strategy استراتيجية الأبعاد السداسية :}

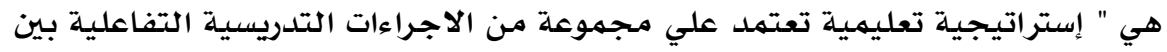

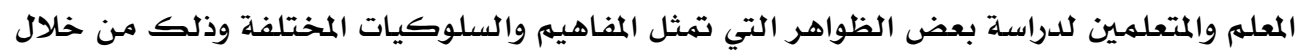

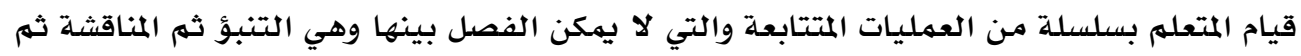

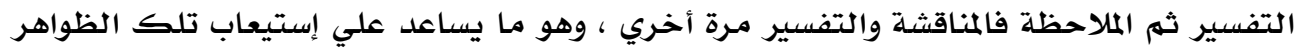

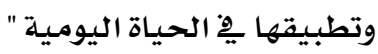

\section{Healthy Concepts المفاهيم الصحية}

هي " مجموعة المعارف المرتبطة بالوعي الصحي والتي يمكن إكسابها للطالبات بالمرحلة

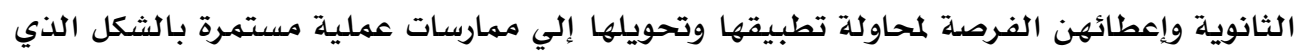

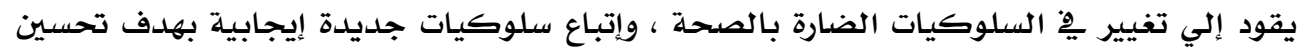

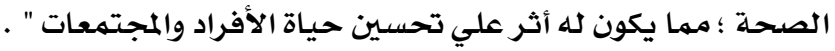

السلوكيات الاقتصادية Economic Behaviors

هي " مجموعة الأنشطة التي تمارسها الطالبة والتي تعكس إستخدامها لبعض المفاهيم

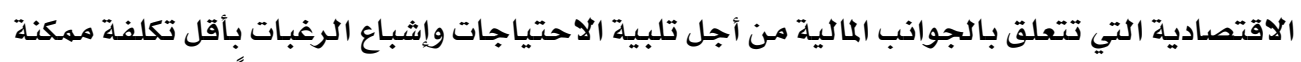

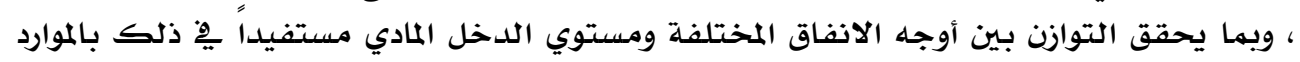

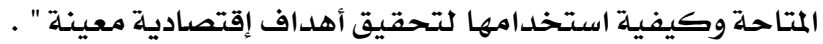

نسروض الدراسة :

استنادا إلى نتائج البحوث والدراسات السابقة وبالرجوع إلى مشكلة وأهداف الدراسة

الحالية تم صياغة الفروض التالية: 


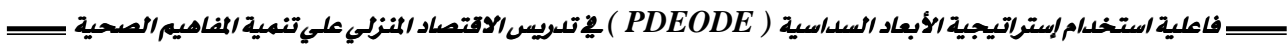
ا - توجد فروق ذات دلالة إحصائية بـين متتوسطات درجـات طالبـات المجمـوعتين " الضـابطة -

التجريبيـة " لاختبـار المفاهيم الصحيـة يِ التطبيق البعدي لصدالح المجموعة التجريبية .

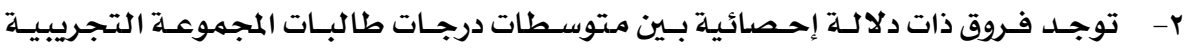

لاختبـار المفاهيهم الصحية يخ التطبيقين " القبلي - البعدي " لصدالح التطبيق البعدي .

r- توجد فروق ذات دلالة إحصائيـة بـين متتوسطات درجـات طالبـات المجمـوعتين " الضـابطة -

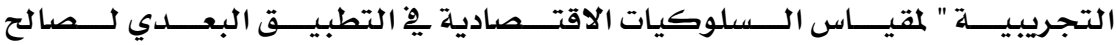
المجموعة التجريبية.

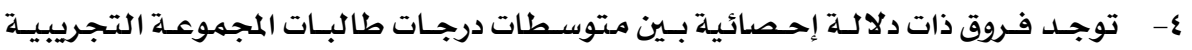

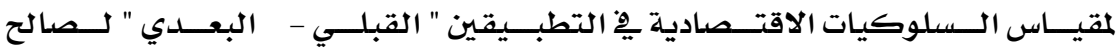

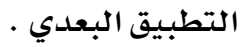

\section{منذهج الدراسة}

استخلدمت الدراسـة الحالية المنهج شبه التجريبي الذي يختبر فيه أثر السبب ( المتغير

المستقل ) علي النتيجة ( المتغيرات التابعة ) والقائم على التصميهم ذو المجموعتين ( الضابطة التجريبية ) حيث تم قياس المتغيرات التابعة ( المفاهيم الصحية - السلوكيات الاقتصادية ) لدي طالبات المجموعتين " الضابطة - التجريبية " عينـة الدراسـة قبل وبعد دراسلة الدروس الخاصة بالمفاهيهم الصحية والسلوكيات الاقتصادية والمتضمنـة بهادة الاقتصاد المنزلي المقررة علي طالبات الصف الأول الثانوي ، وفقاً لاستراتيـجية الأبعاد السداسية ( PDEODE ) لتحديد مدي فاعليتها

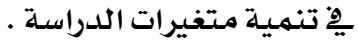

\section{متغيرات الدراسة}

اشتملت الدراسـة الحالية على المتغيرات التالية :

• المتغير مستقل: هو استراتيجية الأبعاد السداسية ( PDEODE ).

• المتغيرات التابعة: هما المفاهيم الصحية ، السلوكيـات الاقتصلادية .

حدود الدراسة

اقتصرت الدراسـة الحاليـة علي الحدود التالية:

ا- الحدود الموضوعية

• المفاهيم الصحية المتضمنـة بهادة الاقتصاد المنزلي للصف الأول الثانوي • • السلوكيات الاقتصادية الرثيدة والمتمثلة ِِ ( ترثيد الاستهلاك - ترشيد الانفاق - فنون الشراء - تخطيط الميزانية - الادخار ) 


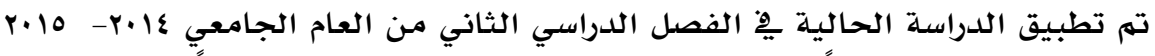

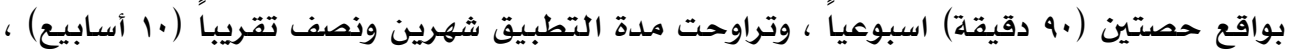

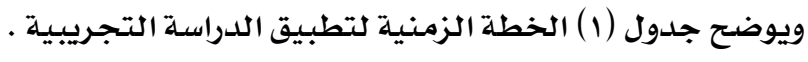

جلدول (1)

الخطة الزمنية لتطبيق الدراسـة التجريبيـة

\begin{tabular}{|c|c|c|}
\hline المدة & الموضوع & مراحل التطبيق \\
\hline 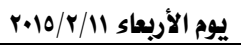 & اختبار المفاهيم الصحية & \multirow{2}{*}{ الأدوات الدبيق القبلي } \\
\hline 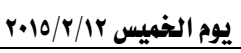 & مقياس السلوكيات الاقتصادية & \\
\hline • 1 أسابيع & دروس المقاهيم الصحية والسلوكيات الاقتصادية & التدريس \\
\hline 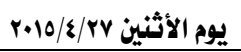 & اختبار المفاهيم الصحية & \multirow{2}{*}{ لتوبيق البعلدي } \\
\hline 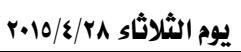 & مقياس السلوكيات الاقتصادية & \\
\hline
\end{tabular}

ب- الحدود المكانية

مدرسة فاطمة الزهراء الثانوية للبنات ، ومدرسة السيدة زينب الثانوية للبنات .

عينة الدراسة ملتة فئة

تكونت عينة الدراسة الحالية من مجموعتين علي النحو التالي:

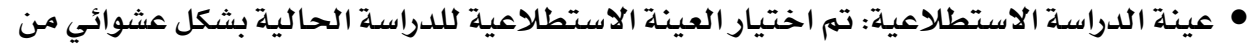

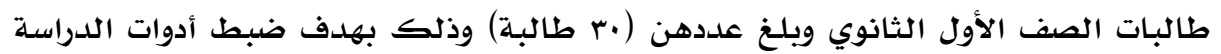

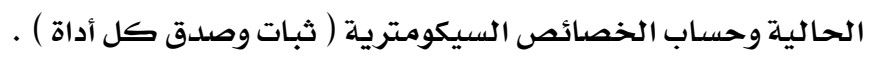

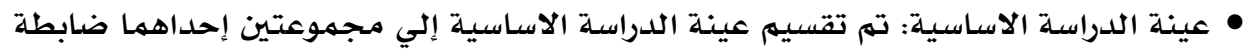

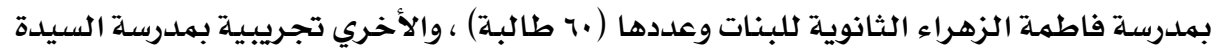

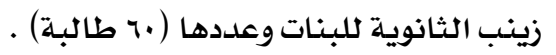

أدوات القيـاس

تضمنت الدراسة الحالية الأدوات التالية:

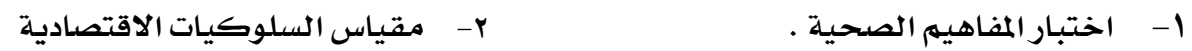

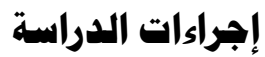

اشتملت إجراءات الدراسـة الحالية علي جـانبين اسـاسيـين هما: 


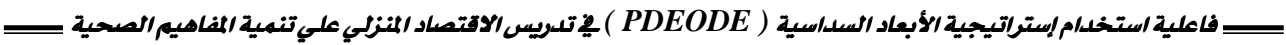

أولاً : الجانب النظري ويتضمن هذا الجانب ما يلي :

ا - الإطلاع على البحوث والدراسات السابقة ذات الصلة للإفادة منها فى إعداد الدراسة الحالية .

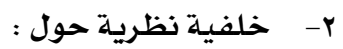

إستراتيجية الأبعاد السداسية PDEODE( مفهومها - أبعادها - مميزاتها - دور المعله

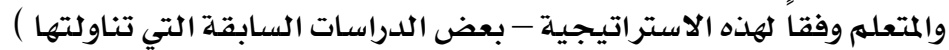

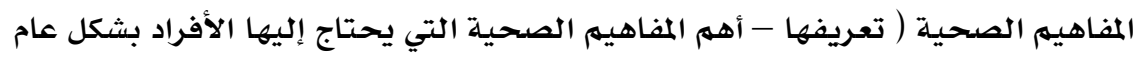

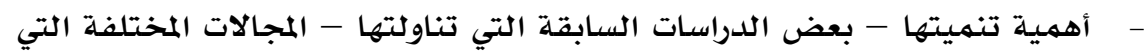

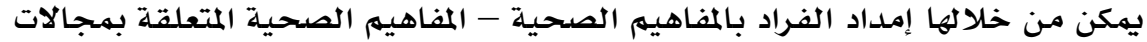

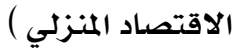

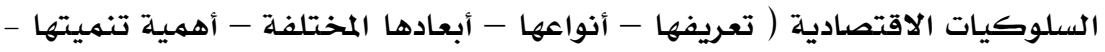

بعض الدراسات السابقة التي تناولتها ) )

ثانياً :ـ الجانب التجريبي ويتضمن هذا الجانب ما يلي :

1- تحليل محتوي كتاب مادة الاقتصاد المنزلي للصف الأول الثانوي لتحديد المفاهيم الصحية

والسلوكيات الاقتصادية المتضمنة فيه ووضع قائمة بتلك المفاهيم والسلوكيات .

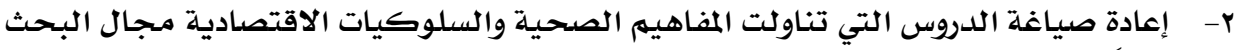

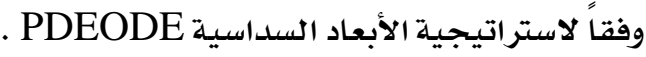

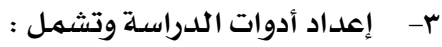

• • اختبار المفاهيم الصحية .

• مقياس السلوكيات الاقتصادية .

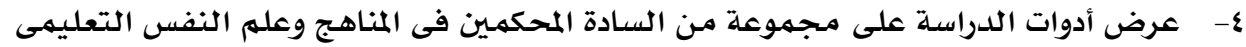

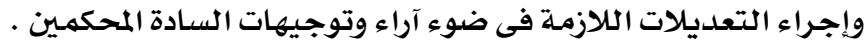

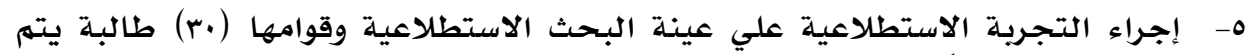

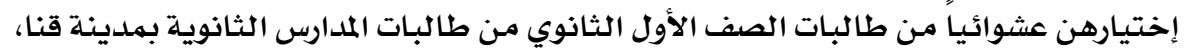

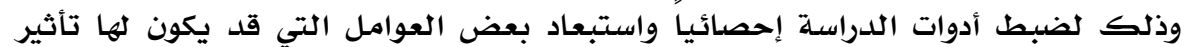

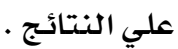

T- اختيار عينة الدراسة الأساسية وتقسيمها إلي مجموعتين ( ضابطة - تجريبية ) ) .

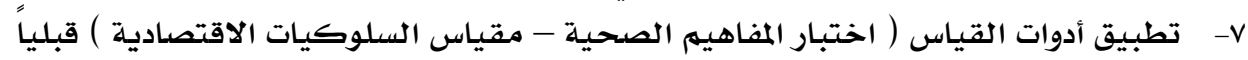

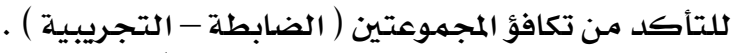

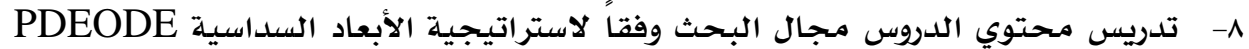

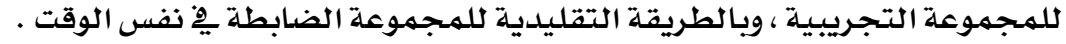

9- تطبيق أدوات القياس بعدياً على عينة الدراسة .

V.. 


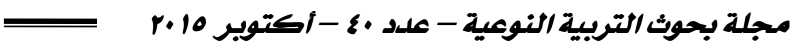

•- - تحليل البيانات ورصد درجات طالبات المجموعتين ( التجريبية - الضابطة ) ومعالجتها

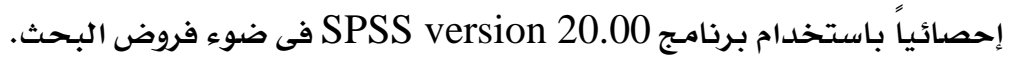

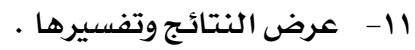

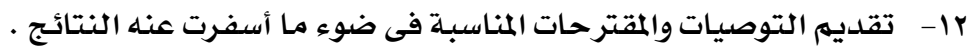

خطوات التصميي التجريبي:

يبين شكل (1) التالي خطوات التصميم التجريبي للدراسة الحالية:

التطبيق البعدي

المعالجات

التطبيق القبلي مجموعتي الدراسة

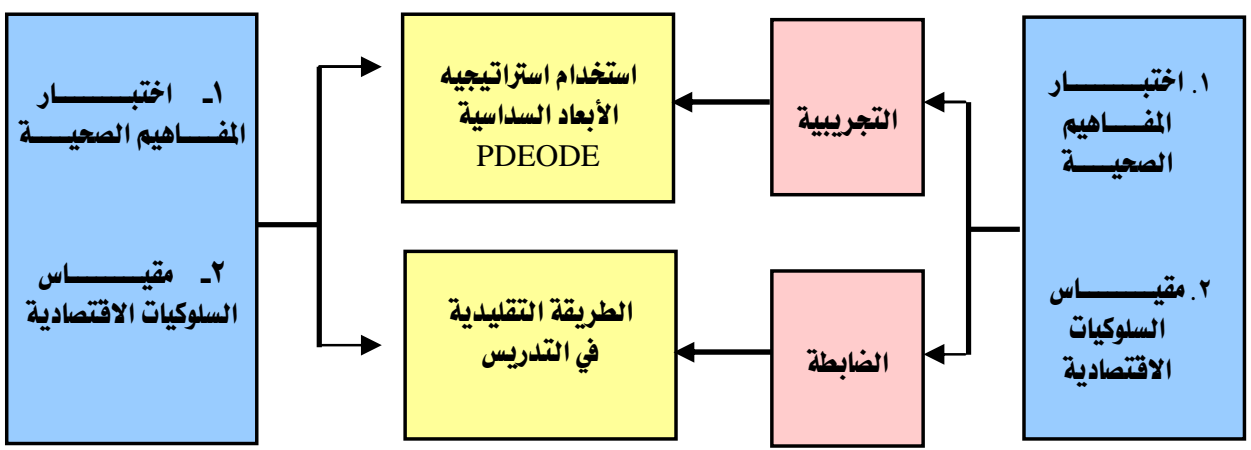

شكل (1)

خطوات التصميم التجريبى للدراسـة

الإطار النظري

أولاً: استراتيجية الأبعاد السداسية PDEODE Teaching Strategy

مقدمة:

اقترح كالً من سافندر وكولاري ( Savender \& Colari, 2003 ) استراتيجية حديثة

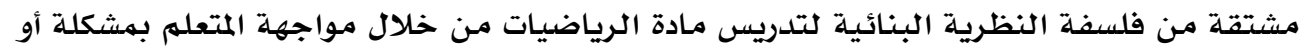

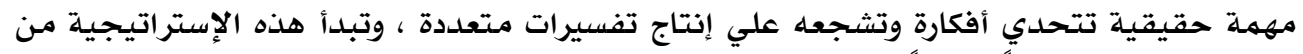

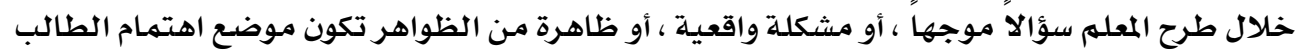

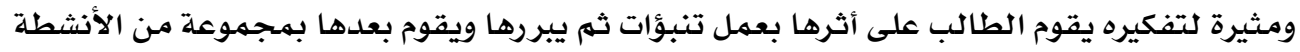

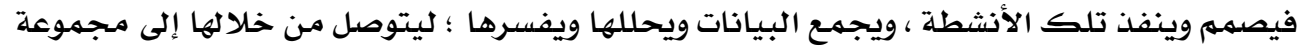

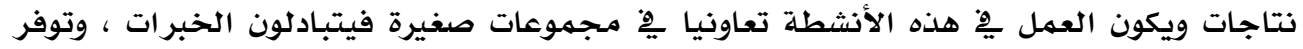

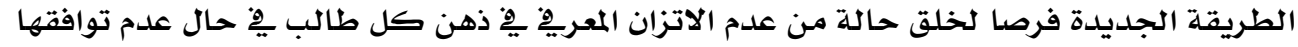

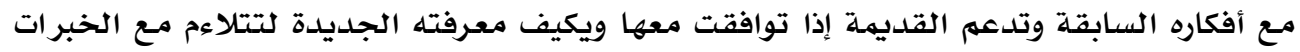

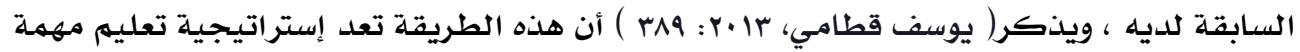




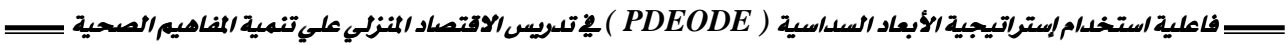
لأنها تعطي مُناخـا يتمتحع بـانقاش، وتنوع الآراء، كها أنها وسيلة لمسـاعدة الطلاب لفهم الأحداث اليوميـة والتتبـؤ بها .

وتسـاعد تلك الاستراتيجية على تنهية العديد من المتغيرات كالمفاهيم والمهارات والقيم

والسلوكيـات..... وغيرها من المتغيرات ، حيث يقوم عمل وتطبيق استراتيجة الابعاد السداسيـة مـن خلال طرح سؤال أو مشكلة أو واقعة أو ظاهرة مجتمعية منتشرة من قبل المعلم، تكون محط اهتمام وتفكير الطلاب، وعلى ذلك يعمل الطالب على طرح بعض النتبؤات والمعتقدات ثم يبررها، ويناقشها مـع افراد مجموعته ويقوم بعدها بجموعة من الخطوات كالتصميه والتنفيذ وجمـع البيانات وتحليلها وتفسير التنبؤات الى أن يتوصل الى مجموعة النتائج لتصور حول تلك الظاهرة من خلال تفحص معرفته السـابقة، وريطها بالمعرفة الجديدة، ثم تكييف المعرفة الجديدة وتعديل البنيـة المعرفيـة السـابقة ، وتتميز هذه الاستراتيجية بنشر روح التعاون والعمل ضهمن مـجموعات، فعملية تبـادل وتناقل الخبر ات بين المتعلمـين توفر سبل جديدة لخلق حالة مـن عدم الاتزان

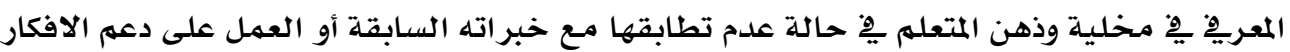

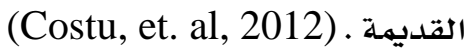

\section{PDEODE مفهوم إستراتيجية الأبعاد السلداسية}

يعرف فخري علي الفلاح (rا ·r) إستراتيجية الأبعاد السداسية PDEODE بأنها : " خطة

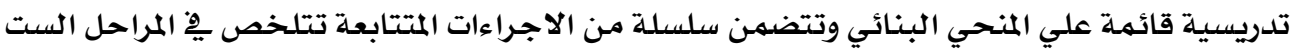

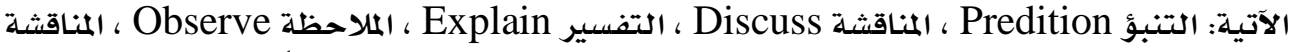

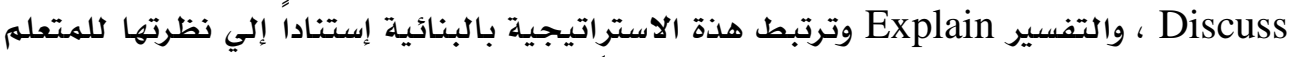

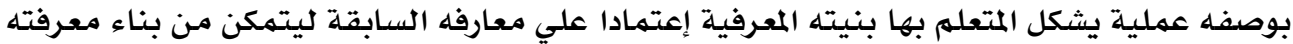

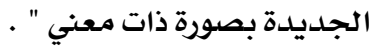

ويعرفها ديوي ( Dewi, 2013 23 ) بأنها " نشاطات منتظمة أثناء التدريس تهدف إلي

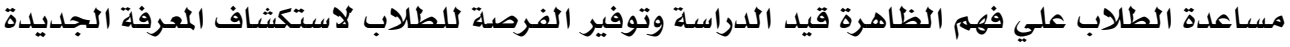

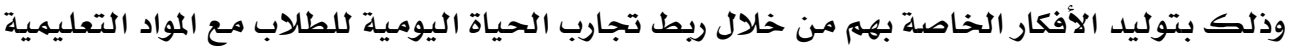

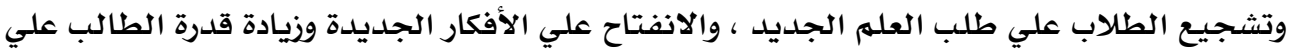

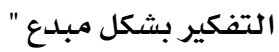

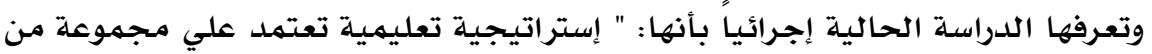

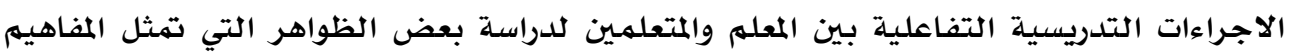

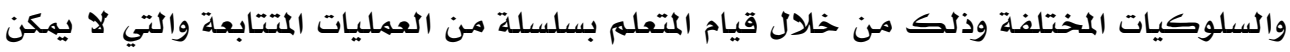

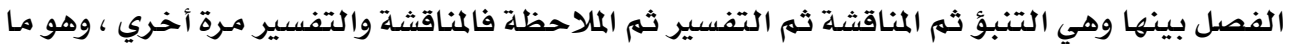

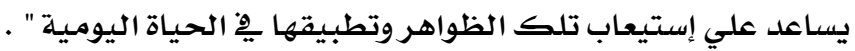


PDEODE أبعاد استراتيجية الأبعاد السلاسية تتكون استراتيجية PDEODEمن ست مراحل يمكن توضيحها علي النحو التالي :

\section{أولاً: التنبؤ Prediction}

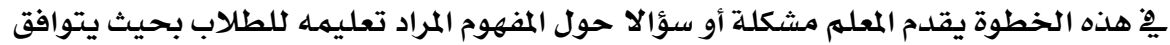

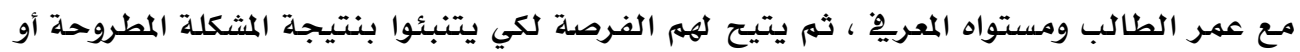

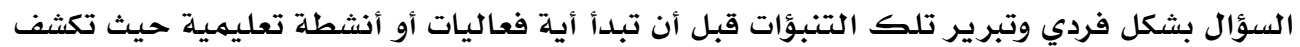

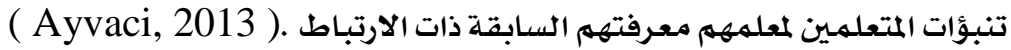
ثانياً: المناقشة Discussion

هِّ هذه الخطوة يتم إتاحة الفرصة للطلاب كي يعملوا ِِّ مجموعات صغيرة من أجل

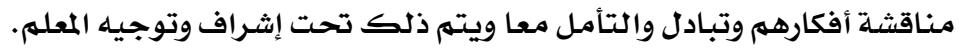
ثالثاً: التفسير Explaination هِْْ هذه الخطوة يصل الطلاب إلى حل تعاوني حول الظاهرة أو المشكلة أو السؤال، وتبادل

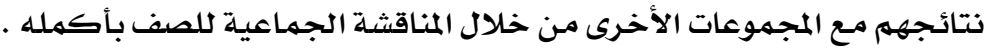
رابعاً: الملاحظة Observation هِْْ هذه الخطوة يختبر الطلاب أفكارهم وآرائههم حول المشكلة أو السؤال من خلال إجراء

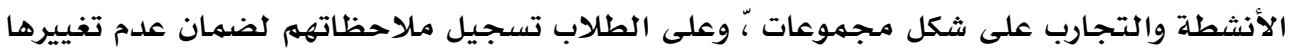

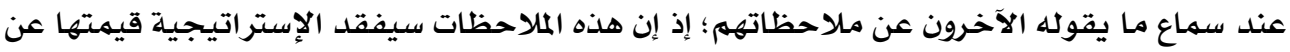

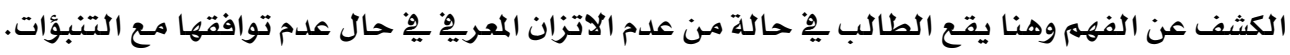
(koseoglu, \& Kavak,2001)

\section{خامساً: المناقشة Discussion}

هِّ هذه الخطوة يقوم المتعلمـين بتعديل تنبؤاتهم من خلال التوفيق بين ملاحظاتهم الفعلية

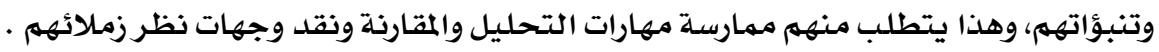
سادساً: التفسير Explaination

هِّ هذه الخطوة يواجه المتعلمـين جميع التناقضات الموجودة بين الملاحظات والتنبؤات من خلال

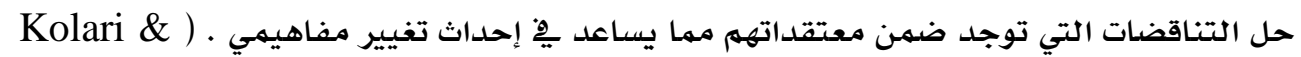
(Ranne, 2005

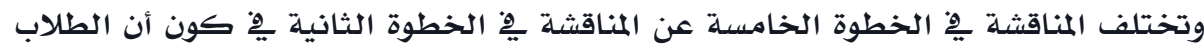

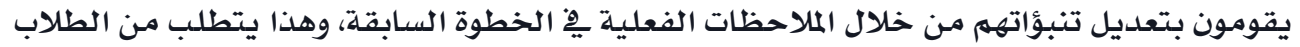

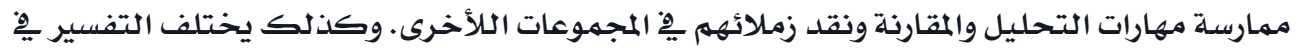

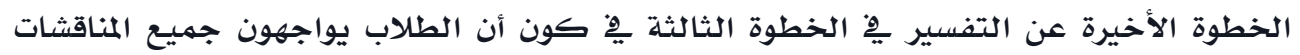




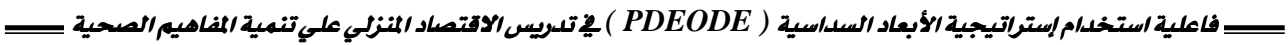
الموجودة بين الملاحظات والتنبؤات، مـن خلال حل التناقضات التي توجد ضهن معتقداتهم، وبالتالي

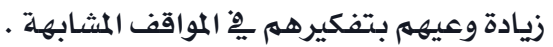

ويوضح شكل (r) التالي العلاقة بين استخدام استراتيجية الابعاد السداسية PDEODE التدريس وإحداث التغييير المفاهيهي لدي المتعلمـين

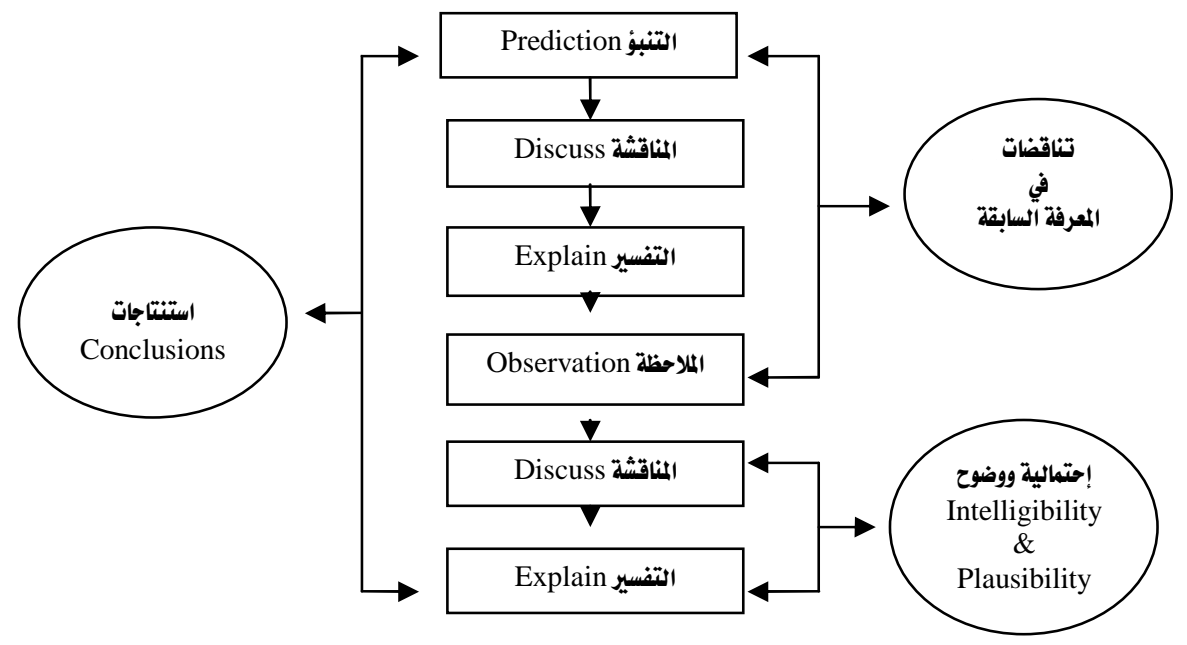

شكل (r)

العلاقة بين استخدام استراتيجية الابعاد السداسية PDEODE يِّ التدريس وإحداث التغيير المفاهيمي (Costu, et . al, 2010)

\section{PDEODE ميزات إستراتيجية الابعاد السلاسية}

إتفق كالً من ( Applefied, et. Al, 2000; Richardson, 2003 (

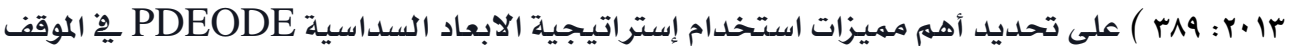

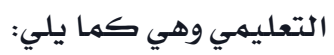

1- تفعيل دور الطالب بِ الموقف التعليمي وجعله محور العملية التعليمية .

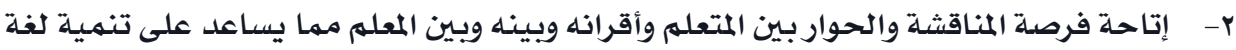
الحوار لديه وإكتسـاب مهارات الحواروالمناقشة . r- جعل المتعلهم يفكر بطريقة علمية مهما يساعد على تنهيـة التفكير العلهى لديه . ع- إتاحة الفرصدة للتفكير ِِّ أكبر عدد مهكن من الحلول المتاحة للمشكلة الواحدة . ه- تشجيع العمل يِّ مجموعات والتعلم التعاوني مها يسـاعد علي تنهية روح التعاون لدي المتعلمـين والعمل كفريق واحد وتنهية العديد من المهارات الاجتماعية لديهم وتدعيهم العلاقات الاجتماعية بين المتعلمـين وبعضهم البعض ، وبينهم وبين معلهيهم . 


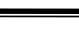

7- تنمية القدرة على ممارسة عمليات العلهم الاساسية والتكاملية كالملاحظة والتتبؤ والتفسير.

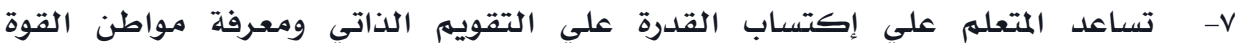

$$
\text { والضعف لديله. }
$$

^- إتاحة الفرصدة لاستخدام مصادر التعلهم المختلفة وعدم الاعتماد على الكتاب المدرسي فقط .

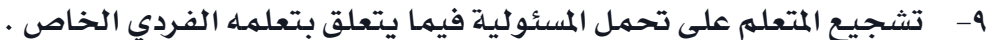

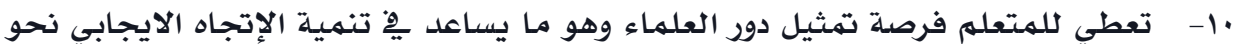

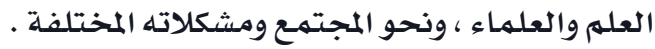

\section{PEDODE أدوار كل من المعلم والمتعلم فى استراتيجية الابعاد السداسية وودية}

(1) دور المعله:

لأن جودة التعليم ونتائج التعلم لا تتحقق ِِّ المواقف التعليمية من ذاتها، وإنما هي نتيجة

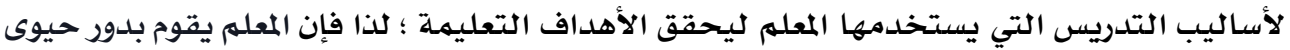

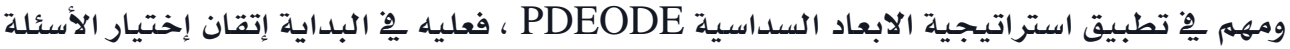

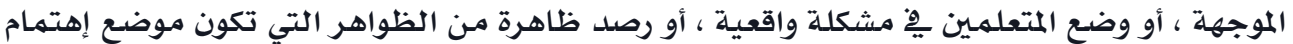

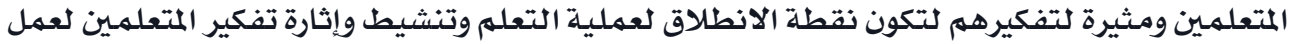

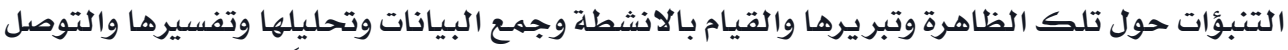

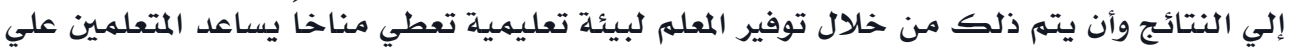

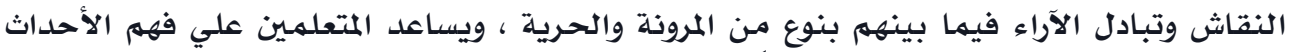

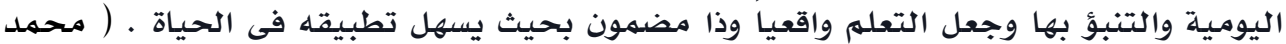

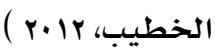

ويهكن تلخيص دور المعله فى ضـوء استراتيجية الابعـاد السداسية PDEODE على النحـو

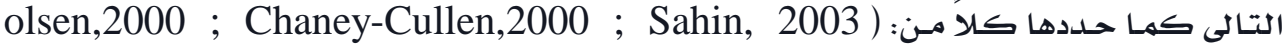
Cousi, et. al, 2012 • يتقبل المتعلهم كفرد باحث مستكثف .

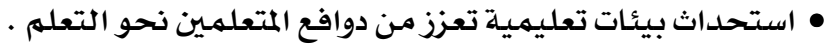

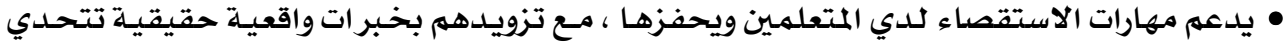

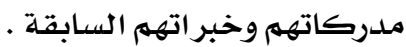

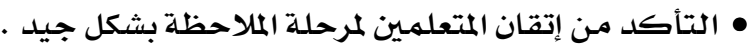

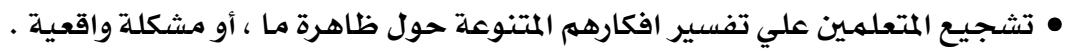

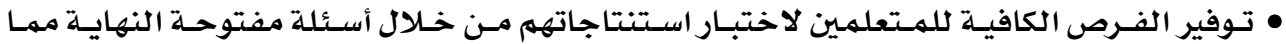

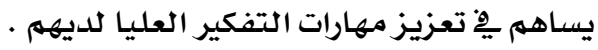

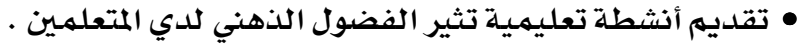

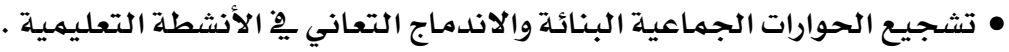




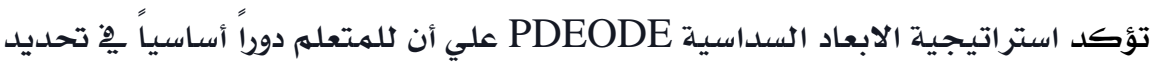

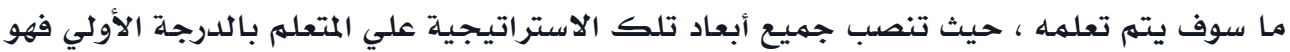

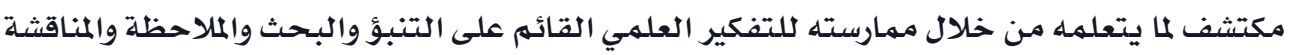

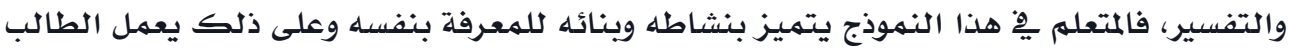

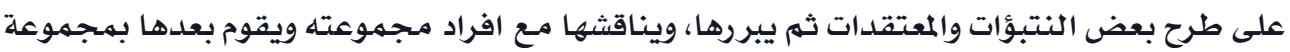

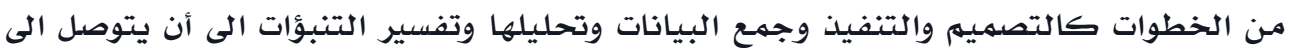

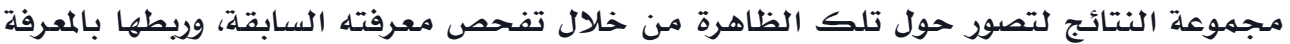

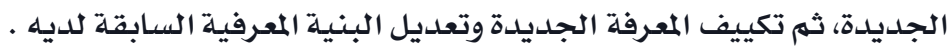

(Jian, \& Yungang, 2013 ; Sholihin, 2013)

وقد اهتمت العديد من الدراسات والبحوث العربية والأجنبية بدراسـة فاعلية استخدام

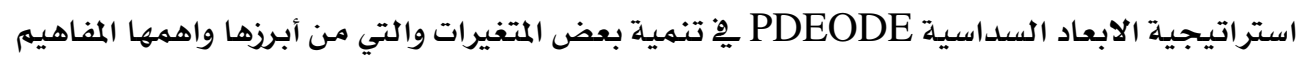

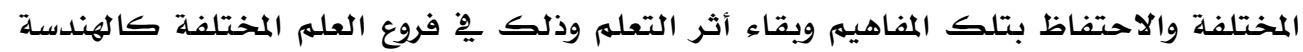

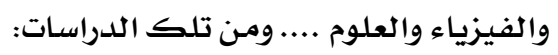

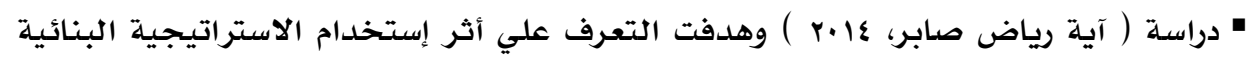
PDEODE

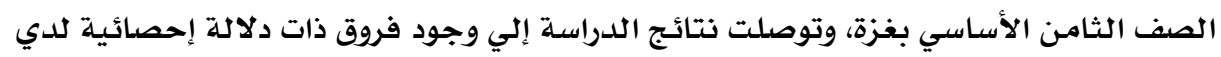

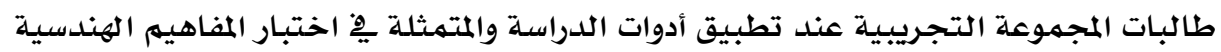

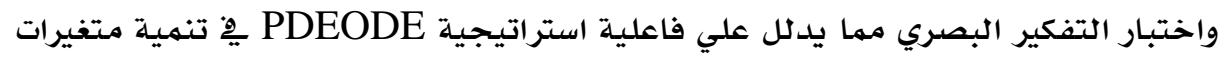

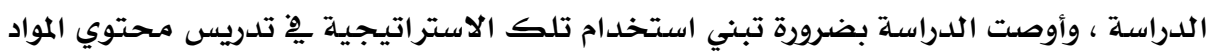

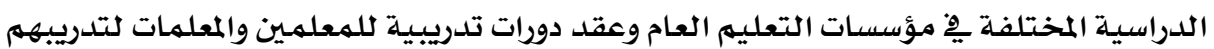
علي كيفية استخدامها.

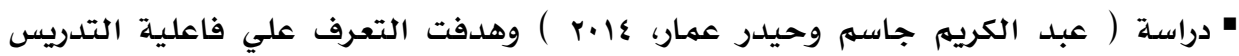

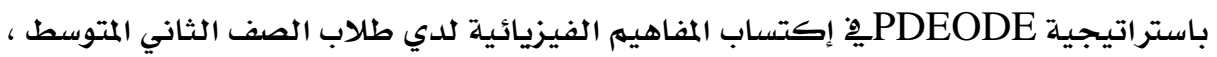

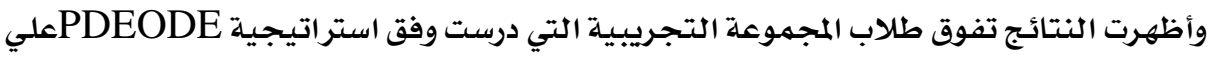

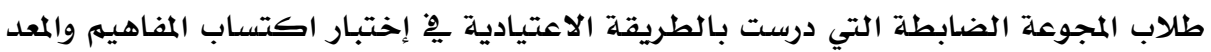

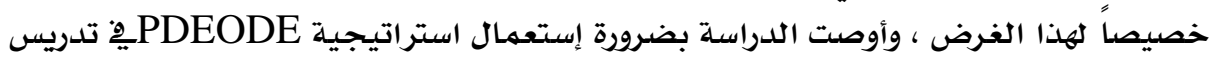

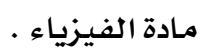

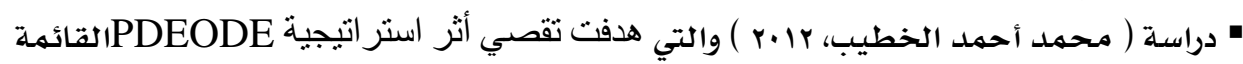

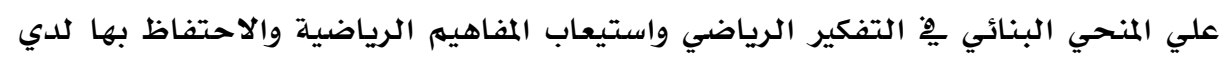

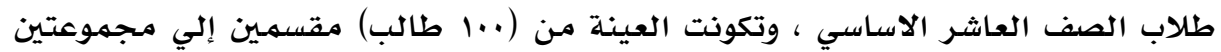




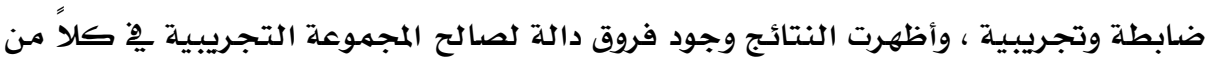

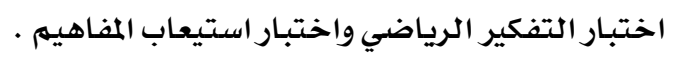

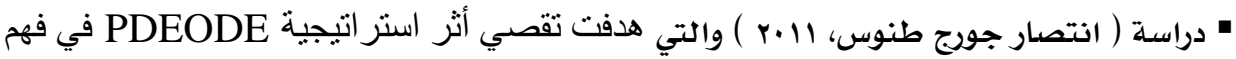

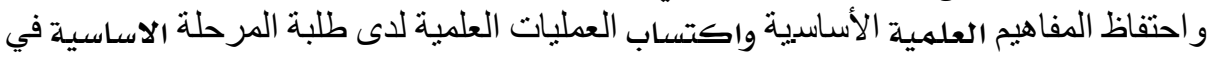

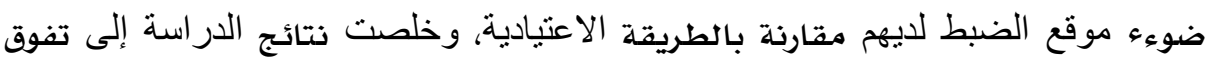

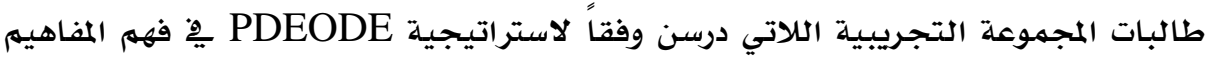

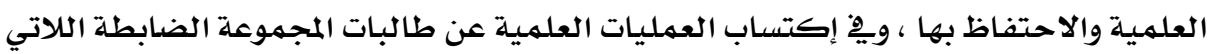

$$
\text { درسن بالطريقة الاعتيادية . }
$$

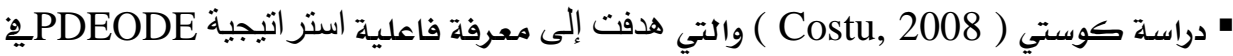

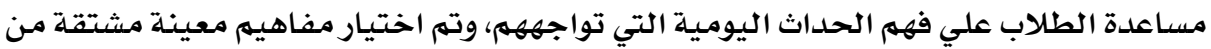

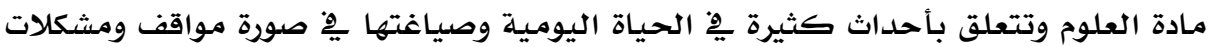

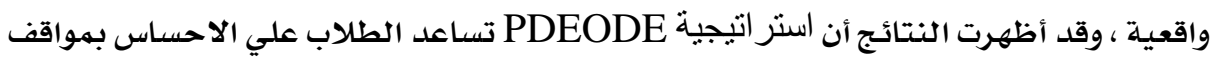

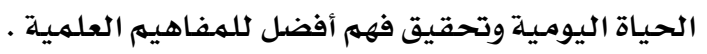

يتضح من الدراسات السابقة إتفاق جميع الباحثين علي إستخدام استراتيجية

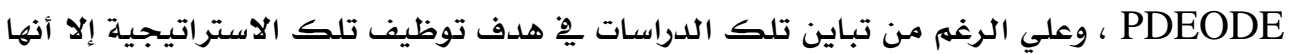

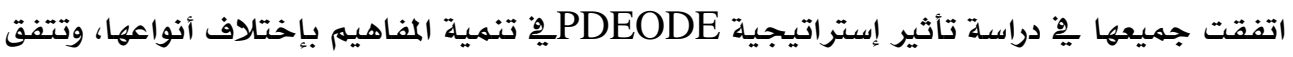

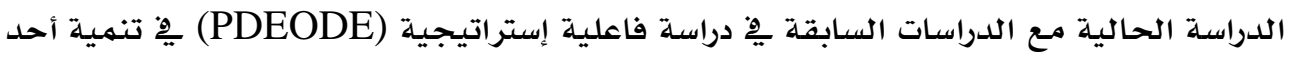

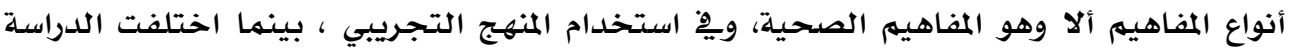

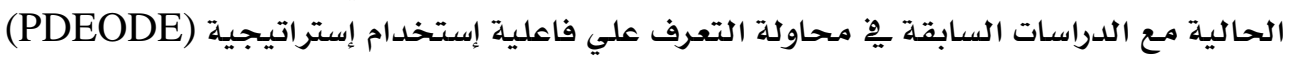

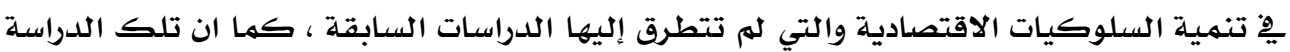

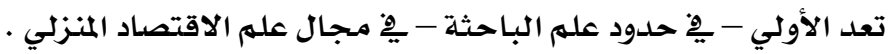

\section{Healthey Concepts ثانيًا: المفاهيم الصيش}

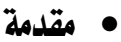

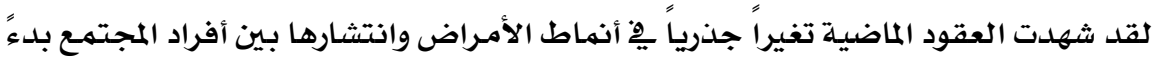

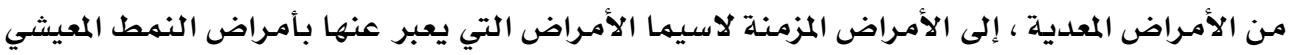

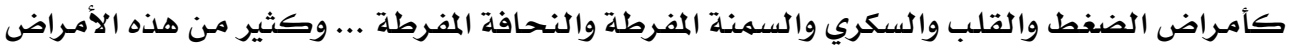

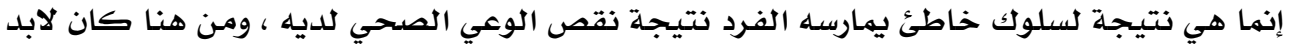

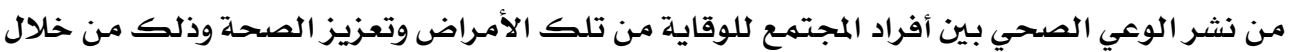

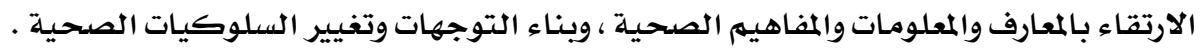

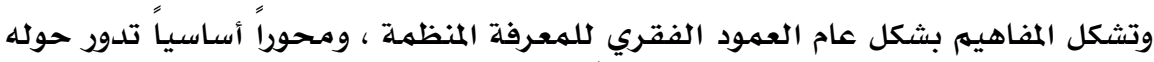

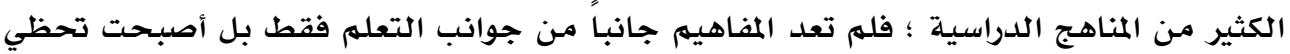

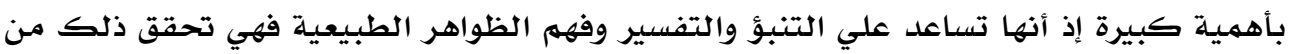




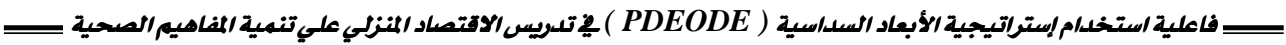

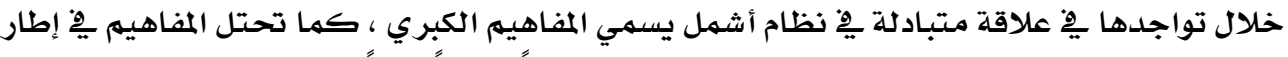

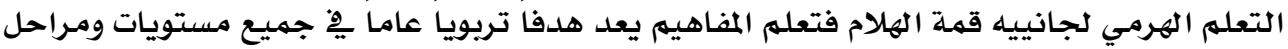

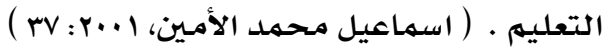

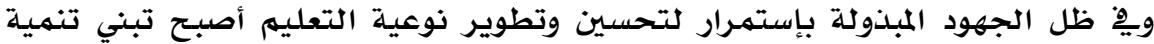

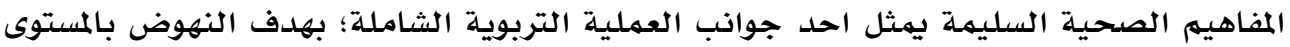

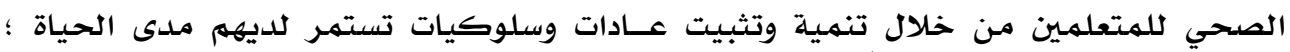

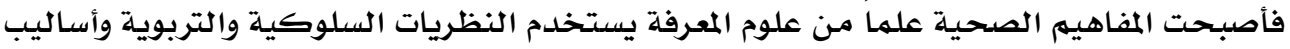

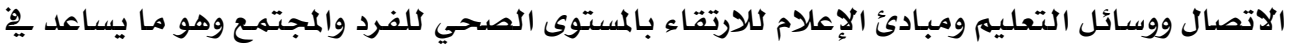

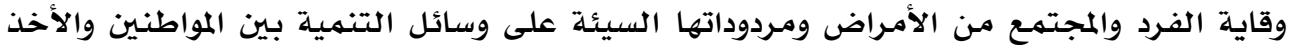

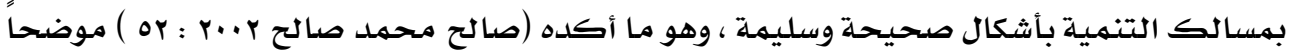

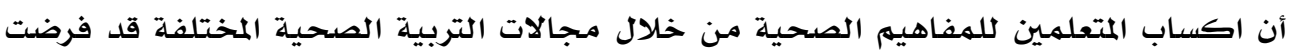

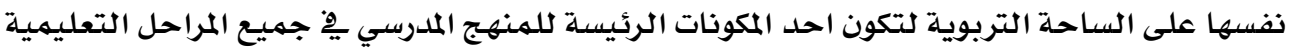

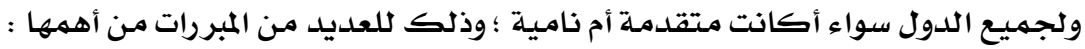

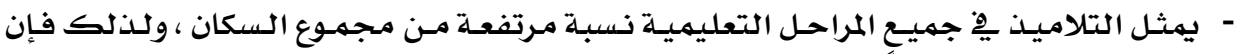

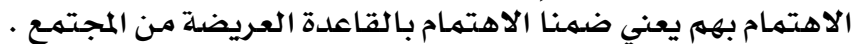

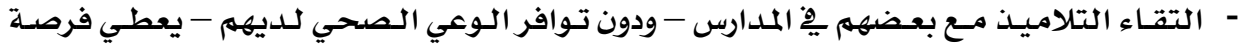

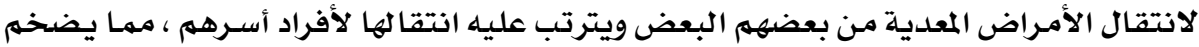

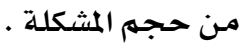

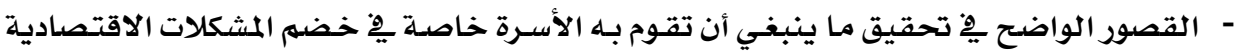

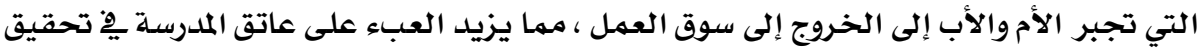

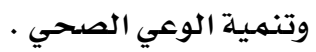

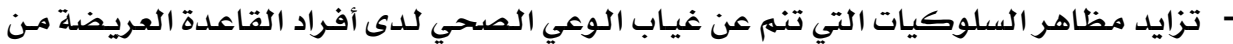

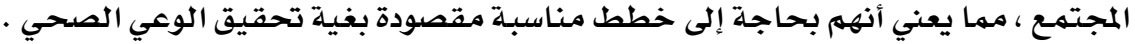

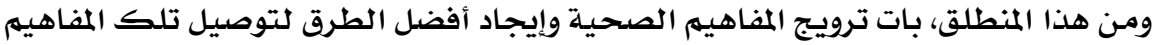

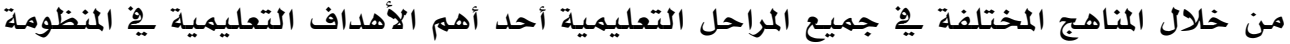

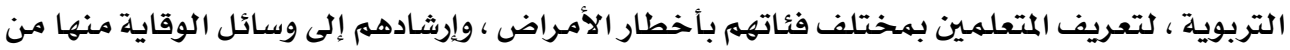

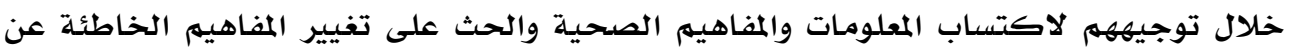

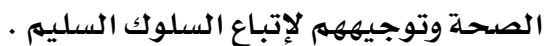
• تعريف المفاهيي الصحية

يعرف هولاندر ( Hollander, 2002 ) المفاهيم الصحية بأنها " مجموعة المعلومات

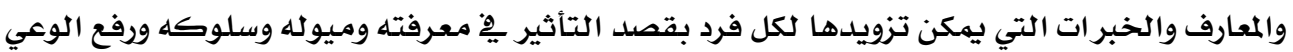

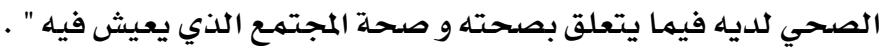


وتعرفها (ليلي أبو المحاسن مرسي، ع +. ب: · 1) بأنها "مجموعة المعلومات والبيانات والحقائق

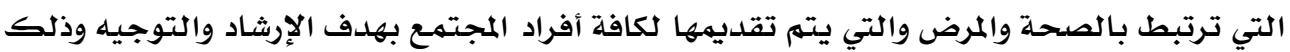

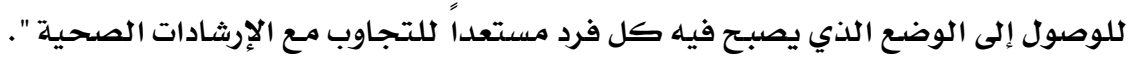

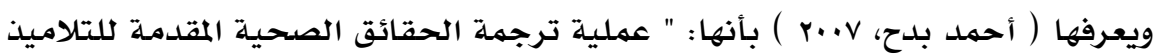

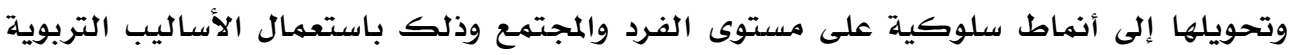

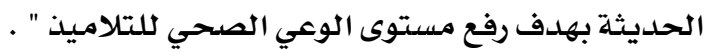

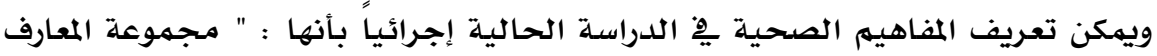

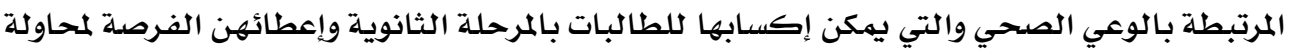

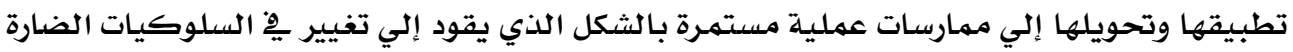

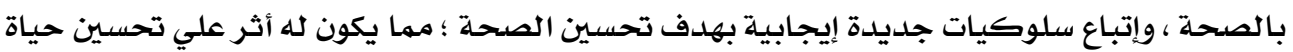

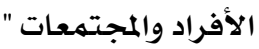

\section{• أهم المفاهييم الصحية التي يحتاج إليها الأفراد بشكل عام}

$$
\text { ترتبط الصحلة بأريع نواحي هي: }
$$

ا ـ الناحية الجسمية وذلك من خلال التمتع باللياقة البدنية وانتفاء المرض والعجز .

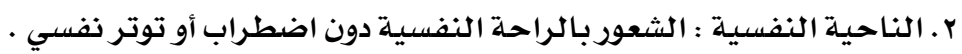

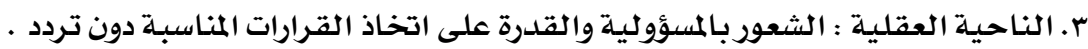

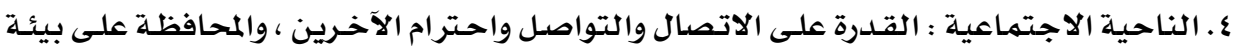

$$
\text { صحية سليمة . }
$$

ولتحقيق تلك النواحي لابد من الاملام بالمفاهيم التي تتضمنها كل ناحية ومن أمثلة

$$
\text { تلك المفاهيه: }
$$

- الأمراض المعدية : هي تلك التي تسببها الكائنـات الحيـة كالبكتيريا والفيروسـات والفطريـات

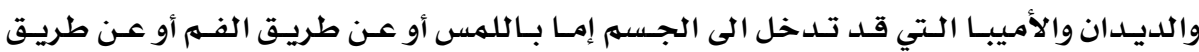

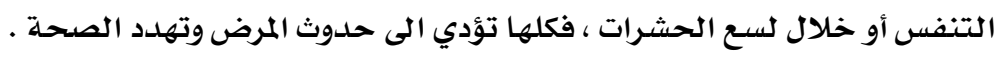

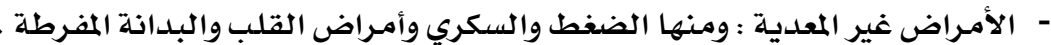

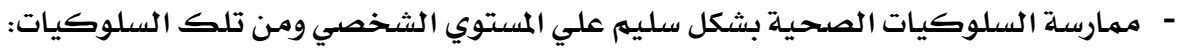

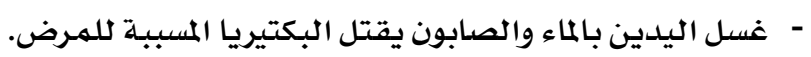

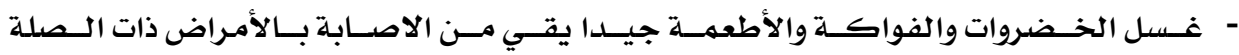

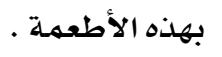

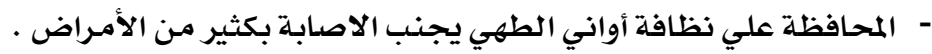

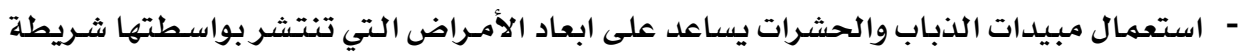




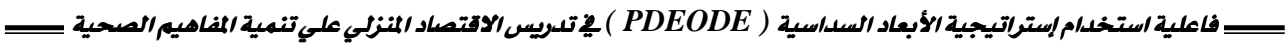

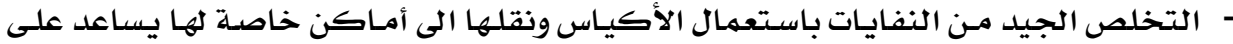

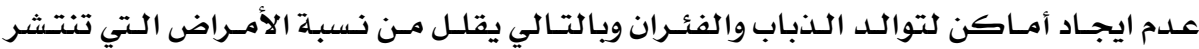
عن طريقها.

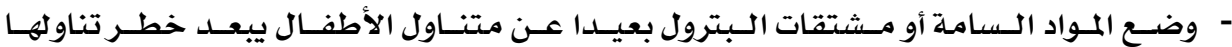
والتسهمى بها. - ممارسـة الألعاب الرياضـية بتحقيق شـروط السلامة مـن خلالها يجنبنـا الإصـابة المباشـرة وغير المباشرة بعاهات تؤثر على صحتتنا.

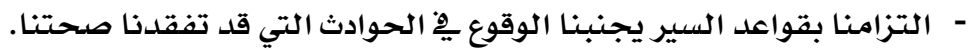

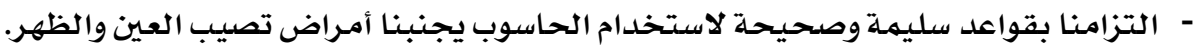

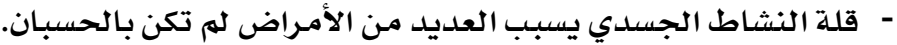
فالوعي والمعرفة بالأمور السابقة يشكل الدرع الواقي من هذه المخاطر والأمراض التي تهدد صححة الناس. أهمية تنمية المفاهيه الصحية

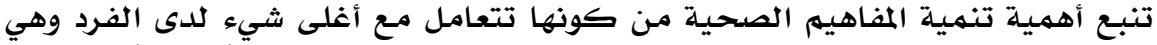

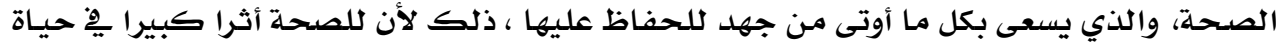

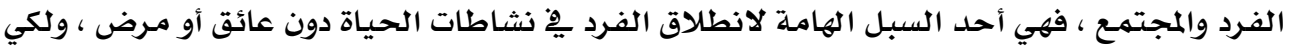

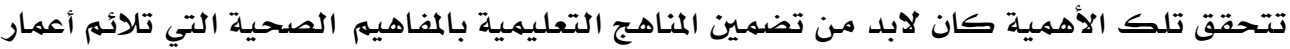

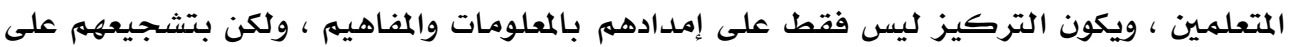

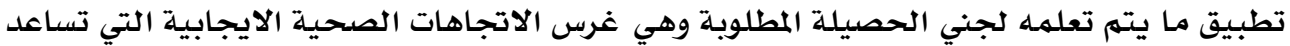

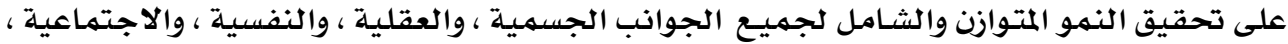

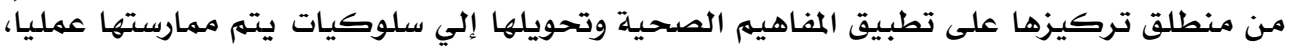

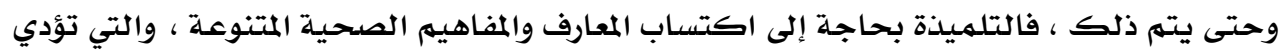

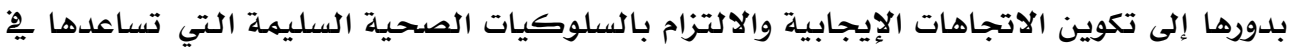

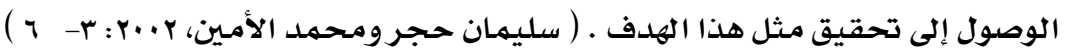

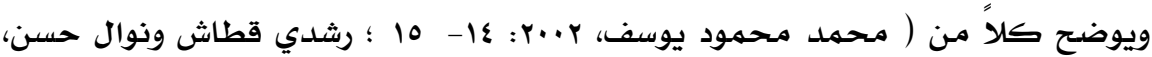

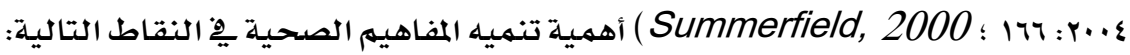
ا- اكتساب المعلومات والمعارف المتعلقة بالوعي الصحي والذي يؤدي بدوره إلي تنمية المسئولية الشخصية لدي كل فرد والقضاء على حواجز الجهل والمفاهيه الخاطئة عن الصحسة والمرضي.

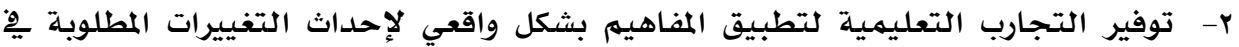

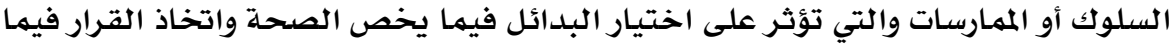

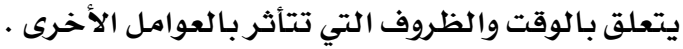




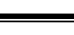

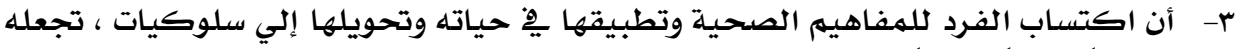

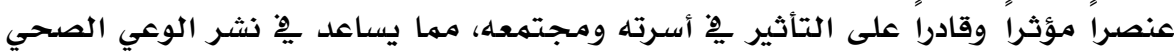

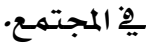

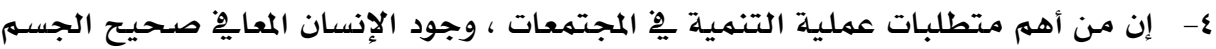

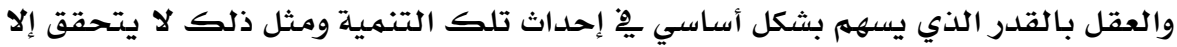

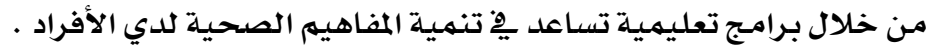

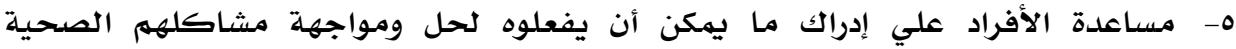

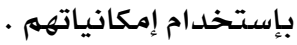

\section{بعض الدراسات السابقة التي اهتهت بتنمية المتهية المفاهيم الصحية}

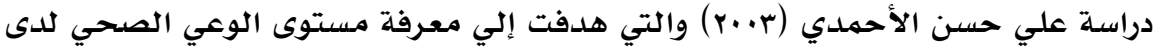

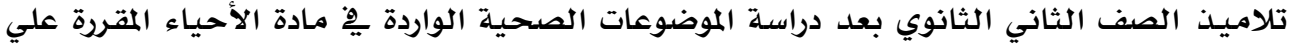

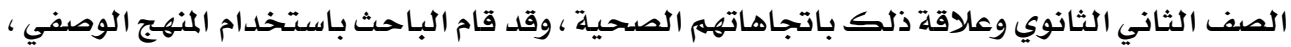

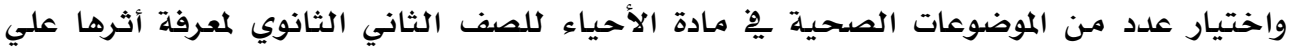

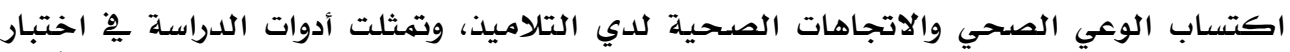

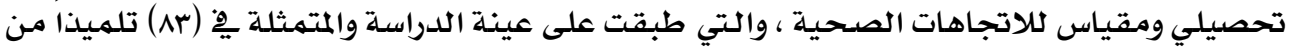

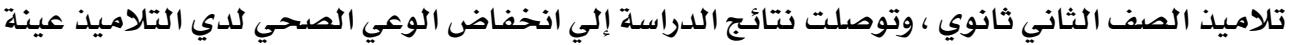

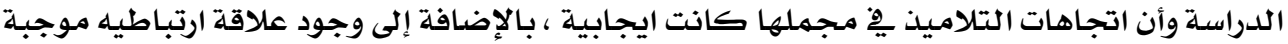

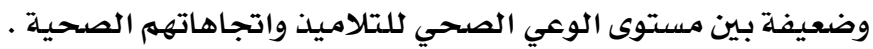

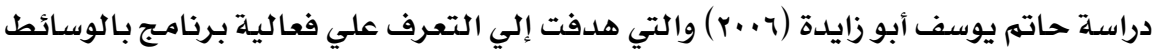

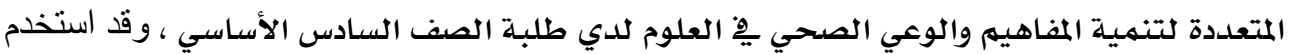

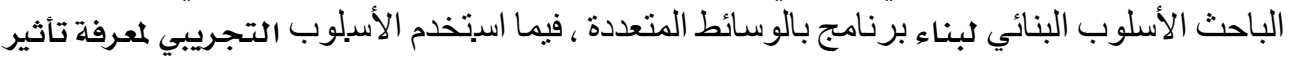
البرنامج علي عينة مكونة من · ج طالب ومقسمة إلي مجموعتين ضابطة وتجريبية ، وتوصلت نتائج

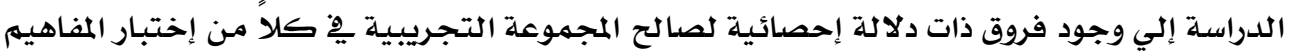

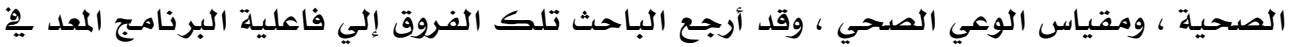

$$
\text { تنميلة متغبر ات البحثث ، ومقياس الموعي }
$$

دراسـة جابهن وكلهر ( Gabhainn\& Kelleher, 2000 ) والتي هدفت إلي معرفة تأثير برنامج ِِّ التربية الصحية علي المعرفة والسلوك والمهارات الصحية لدي طلاب المرحلة الاساسية العليا

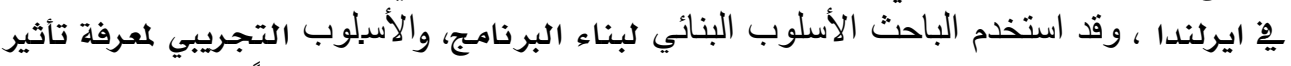

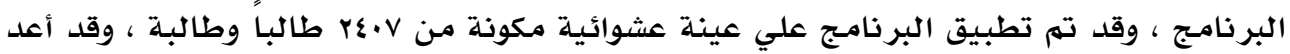

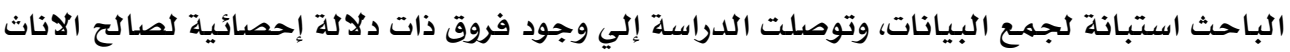

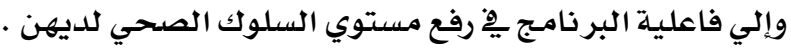




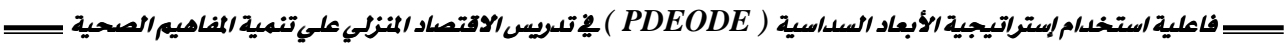
المالات الإتتلفة التي يمكن هن خلالها إمداد الأفراد بالمفاهيم الصحية

نظراً لاهتمام الشعوب والحكومات بضرورة السعي لتحقيق الرعاية الصحية ومواجهة

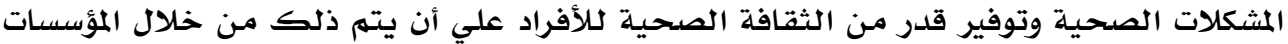

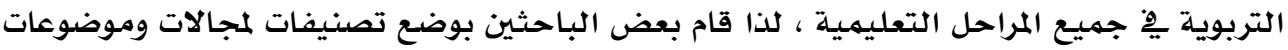

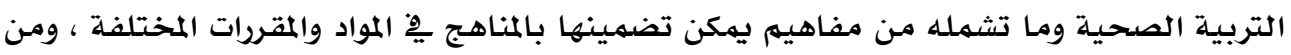

تلك التصنيفات:

\section{أ- تصنيف منظمة الصحة العالمية}

حددت منظمة الصحة العالمية (WHO, 2004 ) مجموعة من البنود والتي يمكن منها

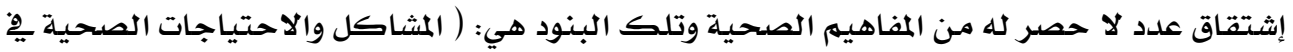

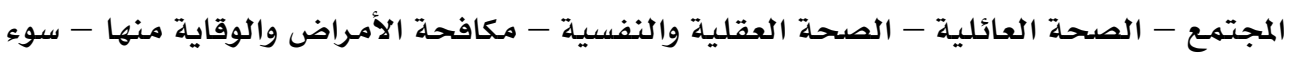

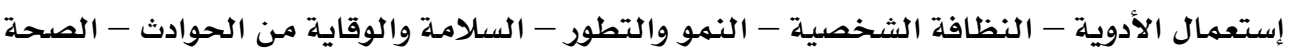

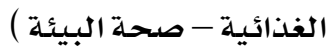

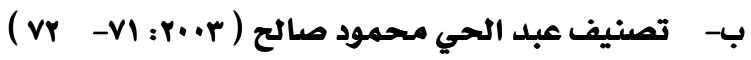

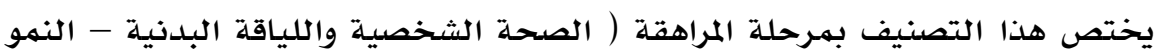

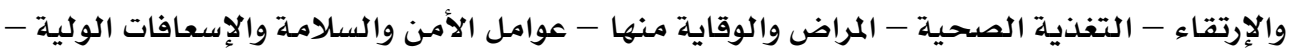

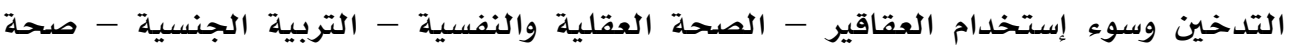

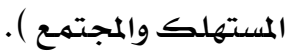

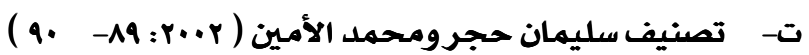

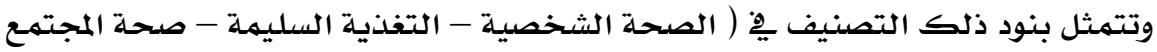

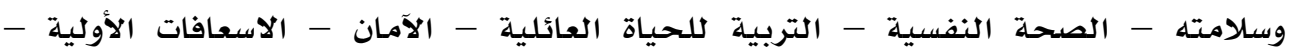

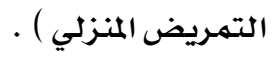

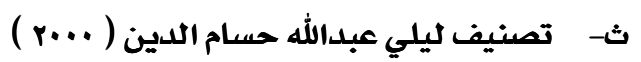

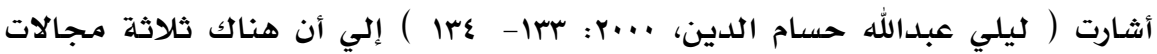

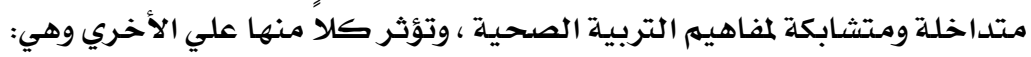
• المجال الأول: الثقافة الصحية الجسمية ويهتم هذا المجال بالصحة الجسمية وما قد يؤثر

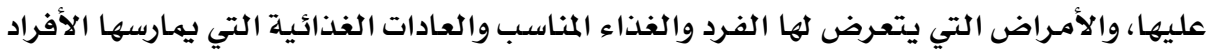

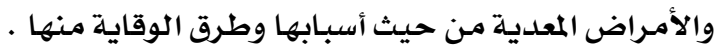

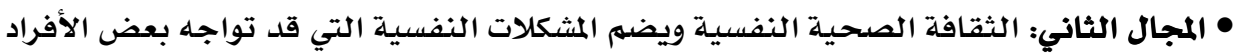

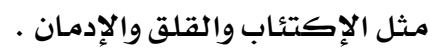

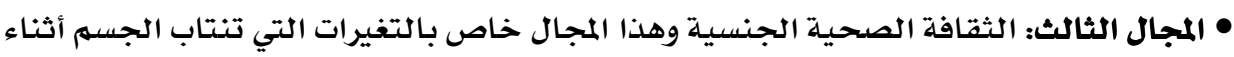

$$
\text { فترة المراهقة . }
$$


يتضح من التصنيفات السابقة وما ورد فيها من مفاهيهم تحتوي علي الجوانب الصحية التي

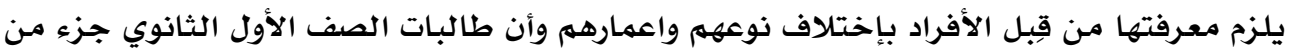

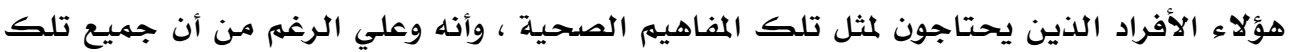

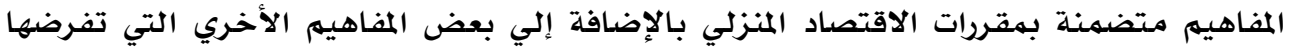

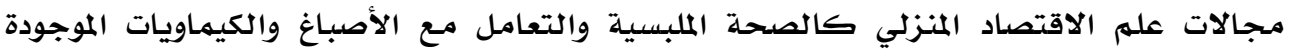

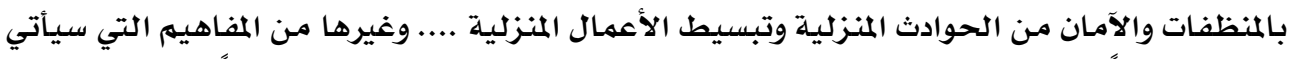

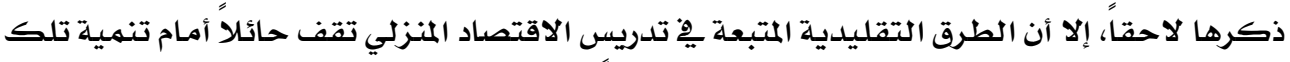

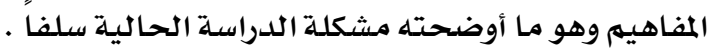

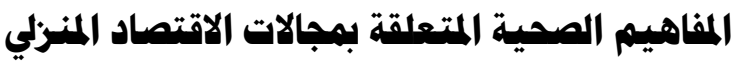

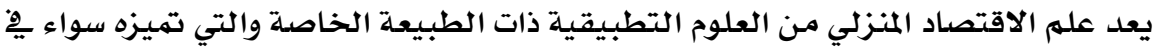

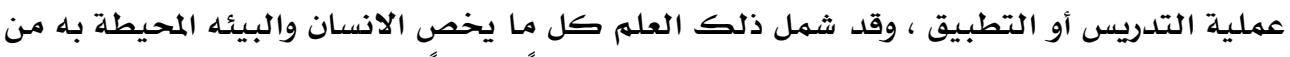

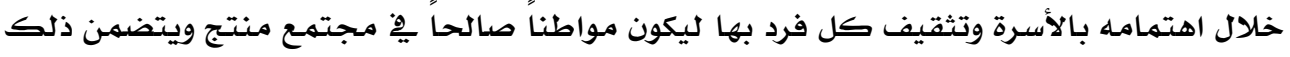

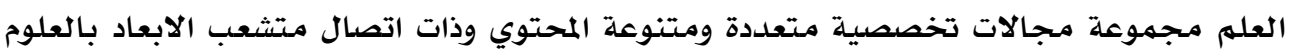

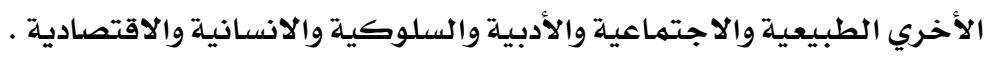

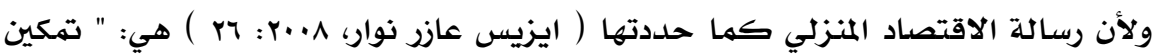

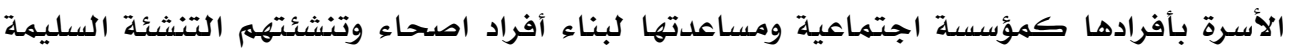

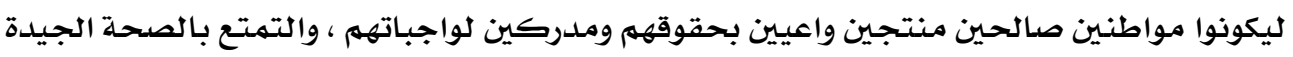

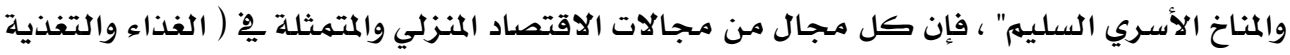

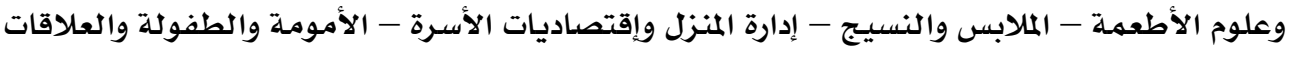
الأسرية - المسكن وتأثيثه وتنسيقه ) يتضمن بعض الأعن المفاهيم الصحية التي تساعد علي تنشئة الأفراد

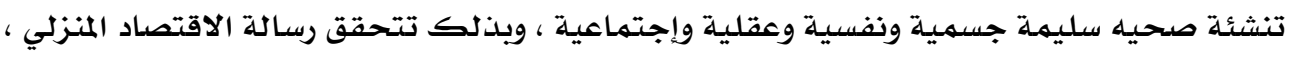

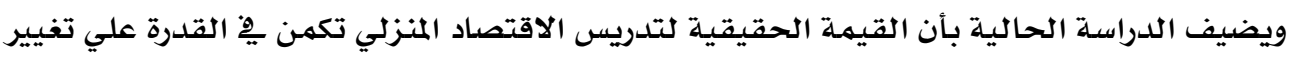

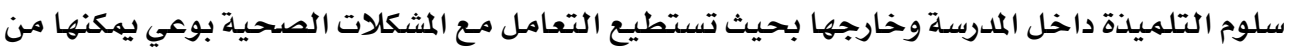

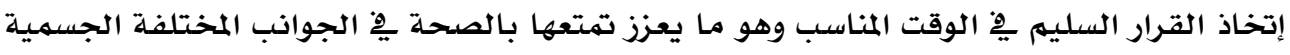

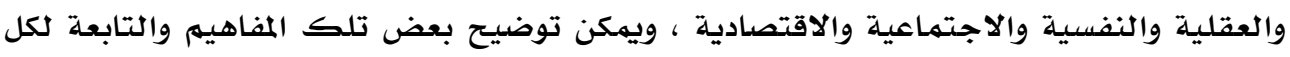

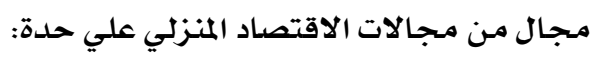

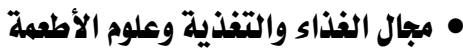

يهدف هذا المجال إلي تحقيق الصحة الغذائية وذلك من خلال الالمام بهصادر العناصر

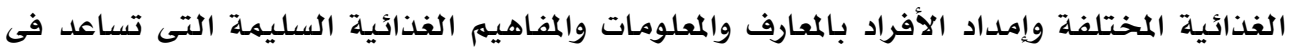

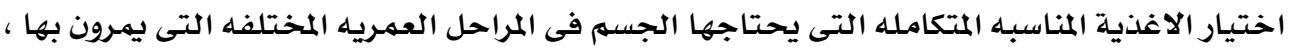

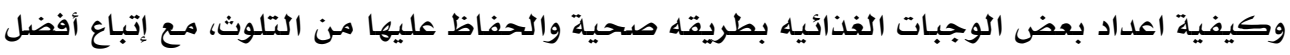

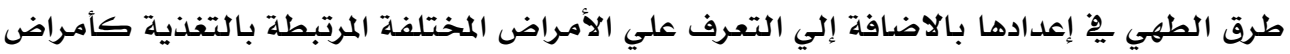




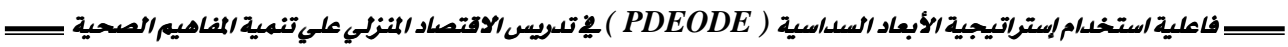
نقص أو سوء التغذية وأسبابها وكيفية الوقاية منها وكذلك الأمراض التي يهكن أن تنتقل عن طريق بعض الأطعمة ، وتعريف الأفراد بالعادات الغذائية الخاطئة والتي من الممكن أن تكون سببـا

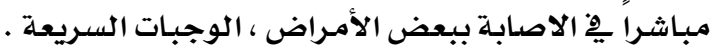
• مجال الملابس والنسيج

يهكن من خلال مـجال الملابس والنسيج تنهية بعض المفاهيه الصحية التي ترتبط بالملبس كأحد الحاجـات الضروريـة التي لا يهكن للإنسـان الإستغناء عنها والتي يسعي دائما إلي توفيرها وتأمينها ، ومن تلك المفاهيهم (تنظيف الملابس والعناية بها - ثأثير منظفات الملابس علي الصحسة الأقمشة الصناعية وتأثيرها علي الصحة - أضرار الملابس الضيقة - تخزين الملابس بطريقة آمنـة التنظيف الجـاف وأضراره علي الصحة - بكتريا وفطريات المنسوجات والملابس ) • مجال إدارة المنزل وإقتصاديات الأسرة

يهتم هذا المجال بالفرد كمستهلك وتوفير الصححة النفسية له وذلك من خلال تعليم الأفراد كيفيـة إختيـار وإستخدام المنتجات والخدمات المتصلة بالصحلة من خلال المعلومـات التي تسـاعد المستهلك علي حسن الاختيـار ما بين السلـع مها يحقق التوافق النفسي والرضا عن الحياة ، ومواجهة المشكلات المختلفة ، كما تتعرف علي كيفية التخطيط لكلأعمال المنزلية المختلفة وتأثير تلك الأعمال علي الصححة، والتعرف علي العادات الصحية وغير الصحيحة . . • مجال الأمومة والطفولة والعلاقات الأسرية

يحقق تدريس هذا المجال بعض الأهداف التي تحمل ِِ طياتها عدد كبير من المفاهيم الصحيـة التي يجب ان تلهم بها الطالبـات وهن تلك الأهداف : ه تدرك العلاقة بين عدد أفراد الأسرة والمستوي الصحي والثقايْ للفرد وسعادة الأسرة . • تلتزم بالعادات الصحية السليمة ، وتعتني بنظافتها الشخصية ومظهرها العام . ه تتعرف علي التطورات الجسهية والنفسية التي تواجه الفتاه فِ مرحلة المرافقة وكيفية التصرف فِّ مواقف حياتها الشخصية • تعرف واجباتها يِ المساهمة والمسـاعدة يخ حالة وجود مـريض بالمنزل .

$$
\text { • تقوم بإجراء بعض الإسعافات الأولية . }
$$

ومن أمثلة المفاهيه الصحية ِِِ هذا المجال ( التثقيف الدوائي - التدخين وأثره علي الصحة

- الصيدلية المنزلية - الإسعافات الأولية - النظافة الشخصيلة - مـرحلة المراهقة ومظاهر النهو بها الأفراد ذوي الاحتياجات الخاصدة - تطعيهم الأطفال ) .

\section{• مجال المسكن وتأثيثله وتنسيقه}

المنزل هو قلعـة الأمان للإنسان، ومكان راحته ولكي يتحقق ذلك الآمان فلابد وأن يكون المنزل صسحي ومـريح ، ومـن المفاهيه الصحيـة التي تتبـع ذلك المجال لتحقيق ذلك الهدف ( المنزل 


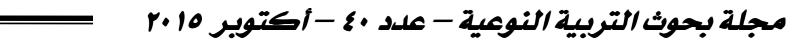

الصحي - الإضـاءة بالمنزل - نظافة المنزل - التهوية - الحوادث المنزلية - تاثيث المنزل - الديكور

والصحسة النفسية الصحي )

ثالثًا: السلوكيات الاتفتصادية الإية Economic Behaviors

• مقدمة

انتشرت بالآونة الأخيرة يِّا المجتمعات المعاصرة بعض السلوكيات الاقتصادية التي تمثل

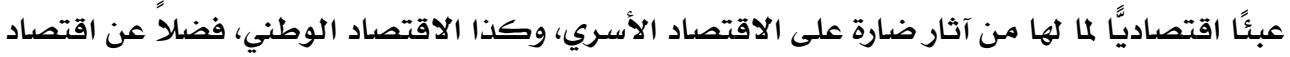

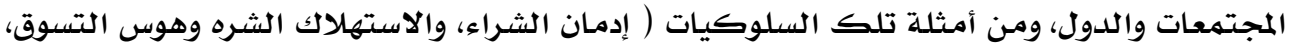

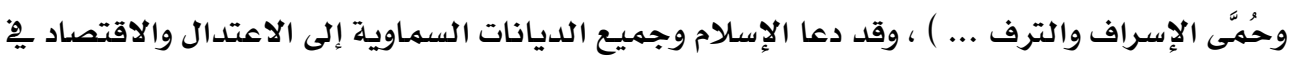

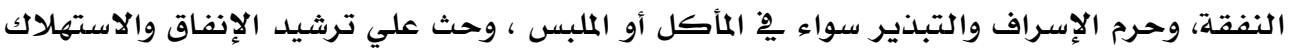

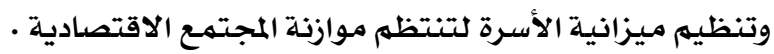

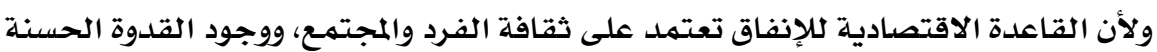

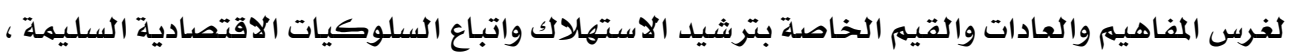

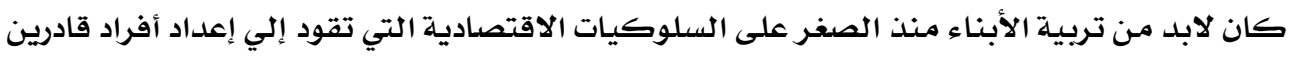

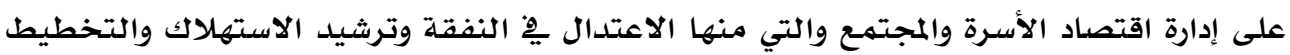

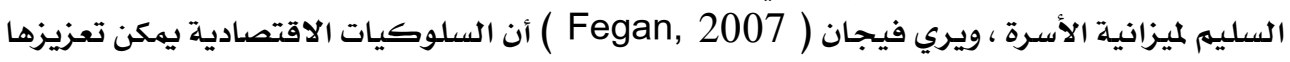

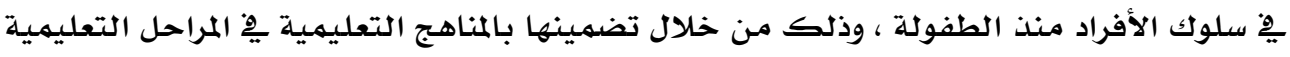

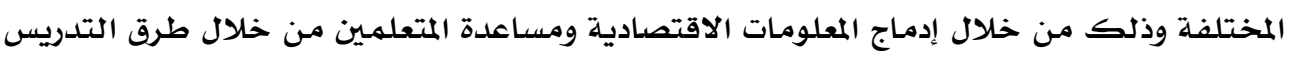

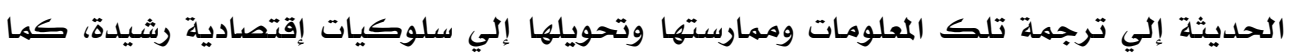

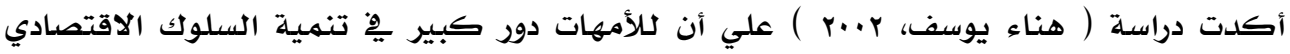

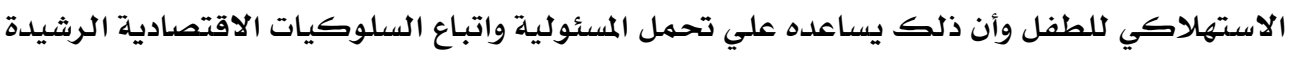

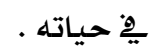

\section{• تعريف السلوكيات الاقتصادية}

يعرف فيليب ( 72 : Philip, 2000) السلوكيات الاقتصادية بأنها : " تلك التصرفات

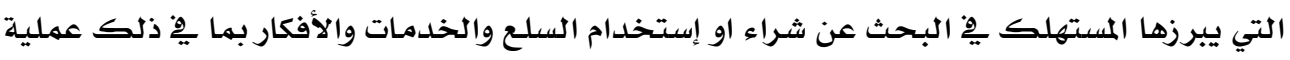

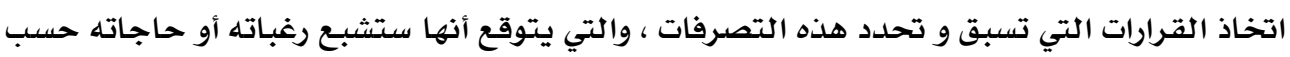

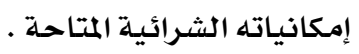

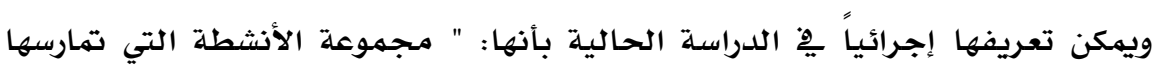

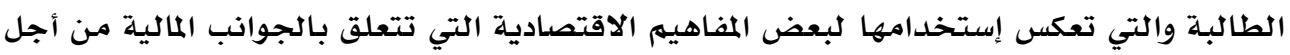

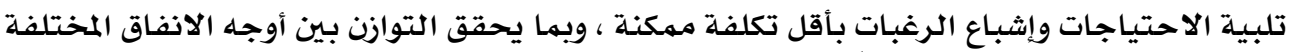

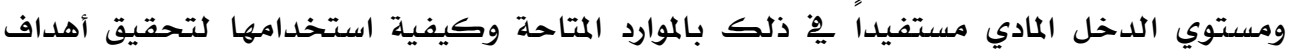

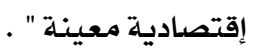




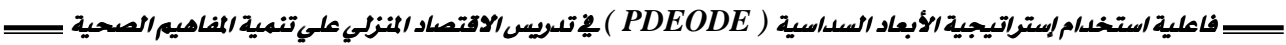

• أنواع السلوكيات الاقتصادية

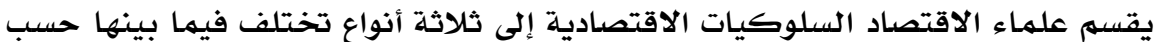

درجة التوافق والانسجام بين طريقة النشاط الذي يمارسه الفرد وبين الأهداف الاقتصادية المراد

تحقيقها ، وتلك السلوكيات هي:

ا- السلوك الرشيد Rational Behavior: وهو توافق الأهداف مـع حركة النشاط

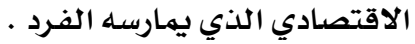

r- السلوك غير الرشيد Irrational Behavior: هو عدم التوافق بين الأهداف وحركة الأدياردي

$$
\text { النشاط الاقتصادي }
$$

r- السلوك العشوائى Random Behavior: هو افتقاد العملية الاقتصادية للأداء السليه للنشاط أو افتقاد الأهداف المرجوة الماف

\section{• أبعاد السلوكيات الاقتصادية الرشيدة}

تسعى الدراسة الحالية إلى تنمية بعض السلوكيات الاقتصادية الرشيدة لدي الطالبات

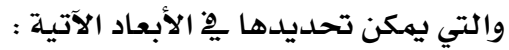

-

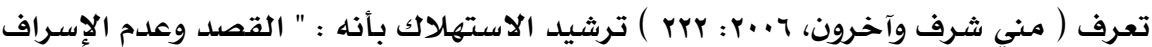

أي التوسط يِّ الإنفاق ِِِ كل ما يتعلق بالغذاء والملبس والمسكن ومحتوياته ومحاولة الانتفاع بالموارد المتاحة إلي أقصي حلد ممكن " .

ويحدد ( ربيع محمود نوفل، ج +. r ) أهم أهداف ترشيد الاستهلاك يِّ النقاط التالية:

ا ـ تبصير المستهلك بحقوقه وواجباته ومده بالمعلومات الأساسية .

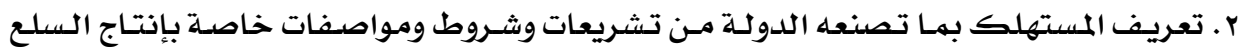

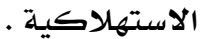

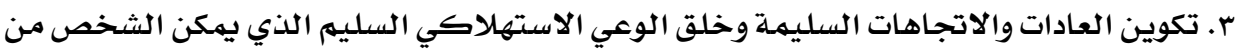

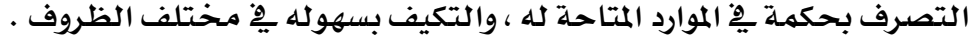

ع. تبصير المستهلك بطرق وأساليب غش السلمع وكيفية الكثف عن ذلك.

0. حماية المستهلك من الاعلانات المضللة.

- ترشيد الانفاق

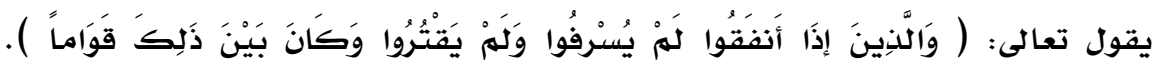

الفرقان (TV)

إن دراية الفرد باقتصاديات الأسرة ومواردها البشرية والمالية والتخطيط السليم للإنفاق

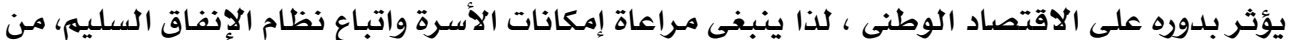

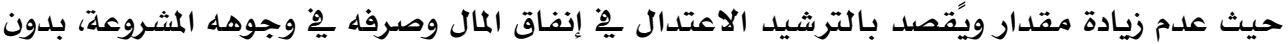




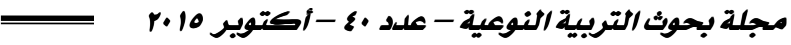

تجاوز أو تقصير، مـع ضرورة توزيع الدخل قدر الإمكان على أبواب الإنفاق المختلفة ، وللانفاق نوعين هما:

أ- الانفاق الاستهلاكي : ويكون يْ شكل شراء احتياجات أفراد الأسرة من طعام وشراب وملابس

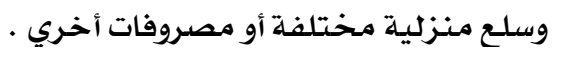

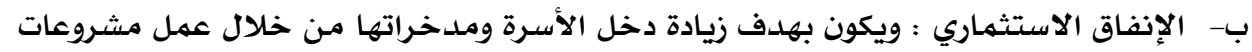

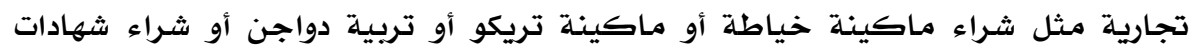

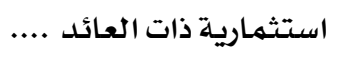

ويقع على رية المنزل الواعية مسئولية المحافظة على الدخل المالى للأسرة ومحاولة

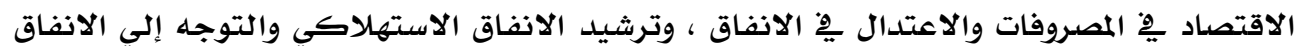

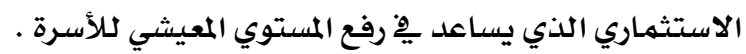

\section{-}

إن عملية الشراء ليست عملية سهلة، كما يظن بعض الناس، بل تحتاج إلى تفكير ودراية؛

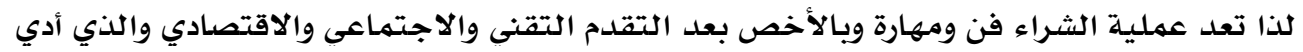

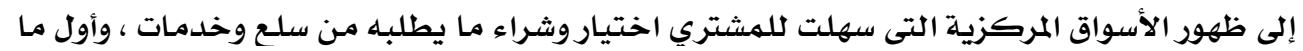

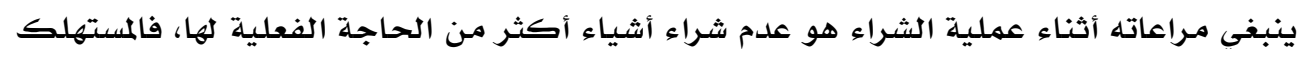

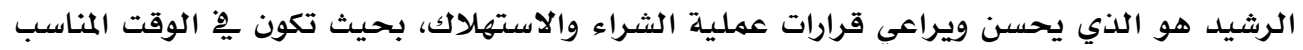

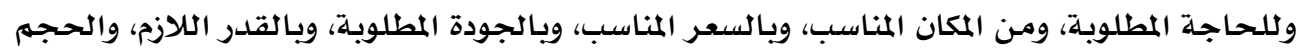

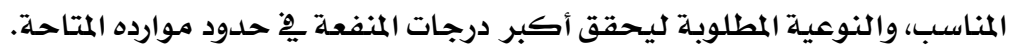

\section{- تخطيط المينانية}

يعد الدخل المالى لكلأسرة أحد العوامل التى تساعد على تحقيق السعادة لأفراد الأسرة

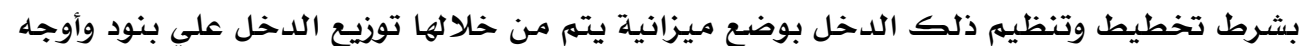

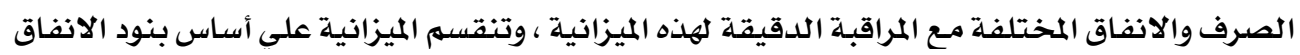

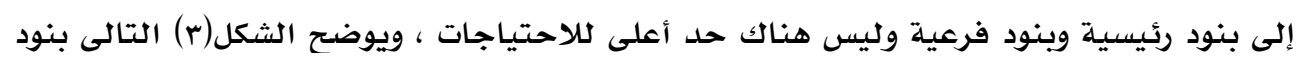

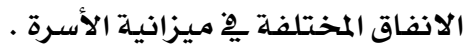




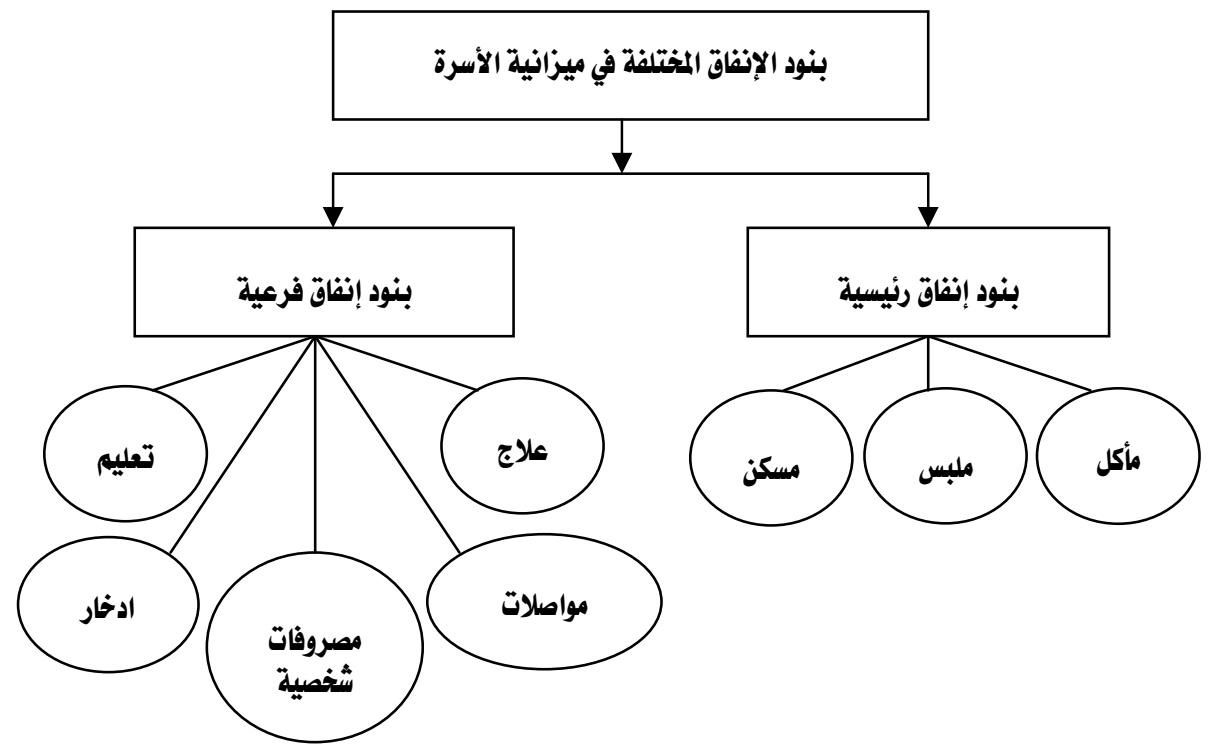

شكل (r)

بنود الانفاق المختلفة يِْ ميزانية الأسرة

ويعد توزيع المستهلك لدخله على بنود الانفاق المختلفة السابقة عملية هامة يوجهها

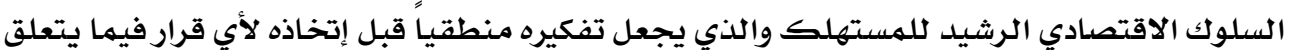
بإنفاق دخلـه. - الادخاد

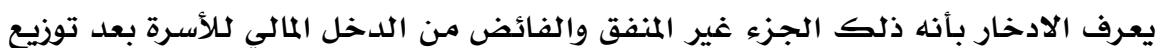

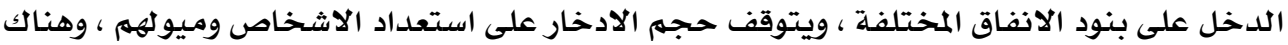

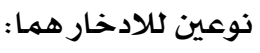
أ- الادخار الاختياري: وهو الذي يصدر عن الفرد بمحض إرادته

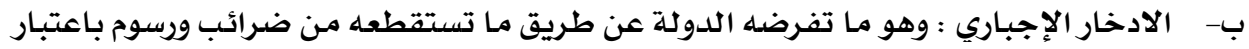

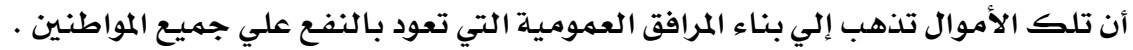
وتهتم الدراسة الحالية بتنمية الإدخار الاختياري بإعتبارة أحد السلوكيات الاقتصادية الرشيدة يِّ الاقتصاد الأسري .

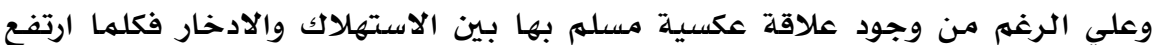

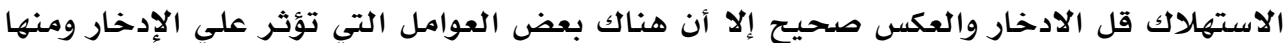

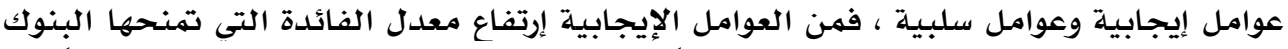

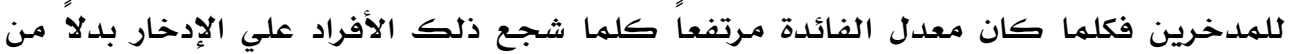


الاستهلاك ، ومن العوامل السلبية تضخم وإرتفاع أسعار السلع والخدمات التى تتسبب يِّ غلاء المعيشة

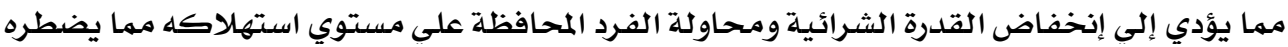

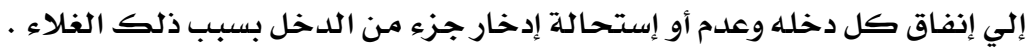

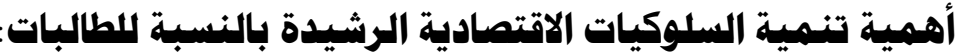

تفيد تنمية السلوكيات الاقتصادية الرشيدة لدي الطالبات ِِّ فهم العلاقة بين العوامل

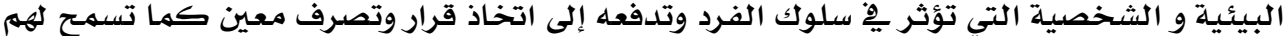

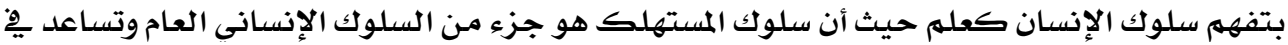

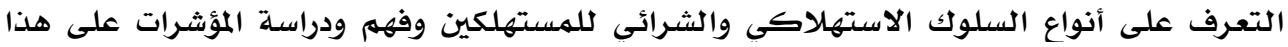

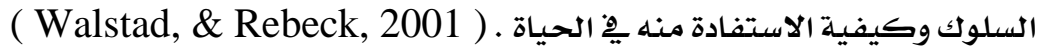

وقد اهتمت العديد من الدراسات بتنمية بعض السلوكيات الاقتصادية ومن تلك الدراسات:

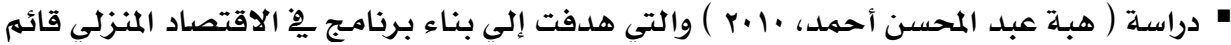

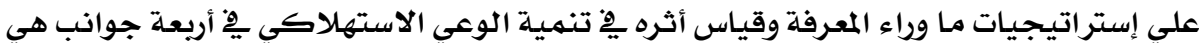

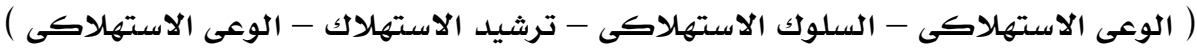

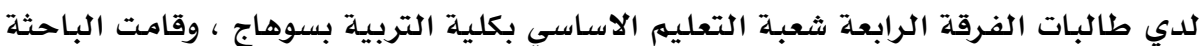

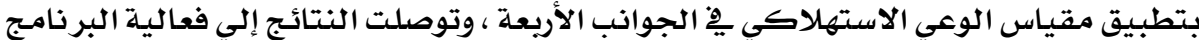

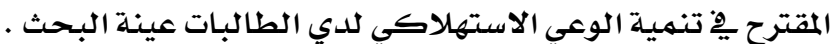

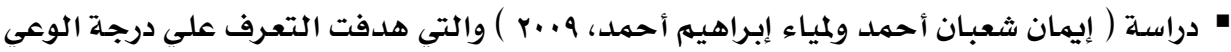

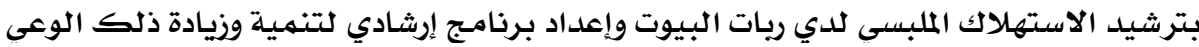

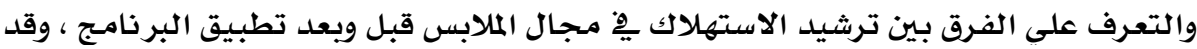

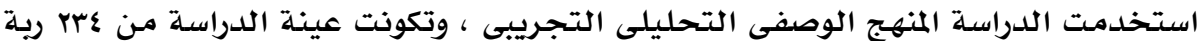

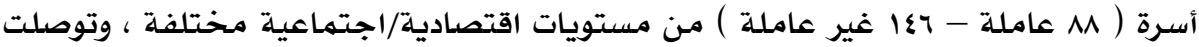

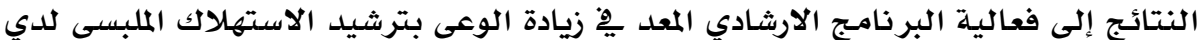
ريـة الأسرة .

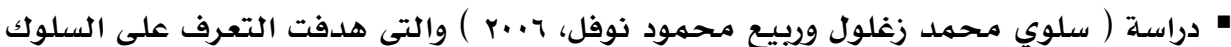

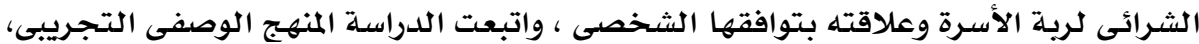

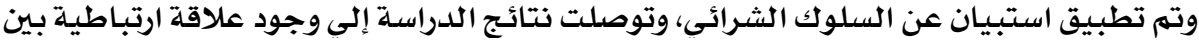

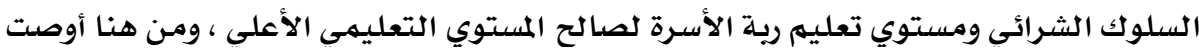

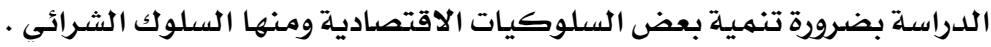

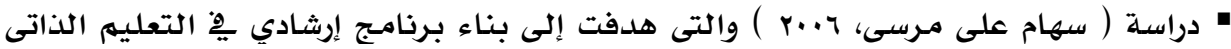

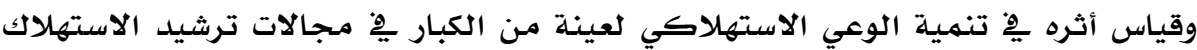




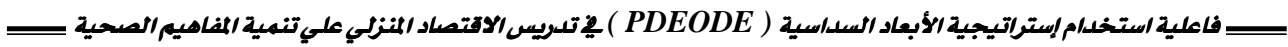

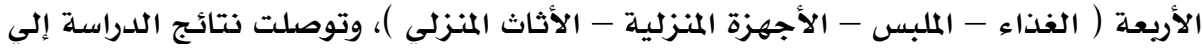

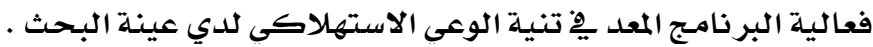

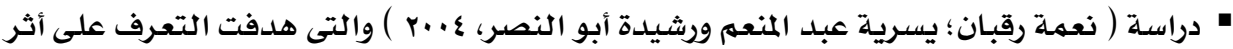

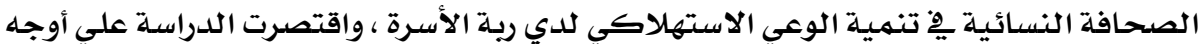
الاستهلاك الغذائي والملبسي واستهلاك المياه والكهرباء ، وطبقت الدراسة ثلاثة استبيانات

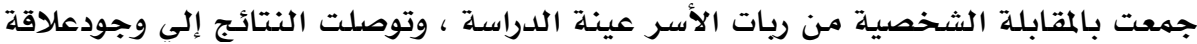

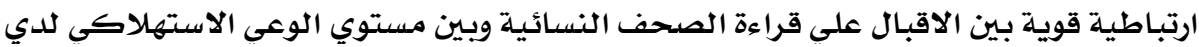

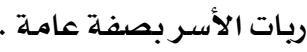

\section{السير في إجراءات الدراسة الاستة}

\section{أولاً ـ تحليل محتوي كتاب الاقتصاد المنزلي للصف الأول الثانوي}

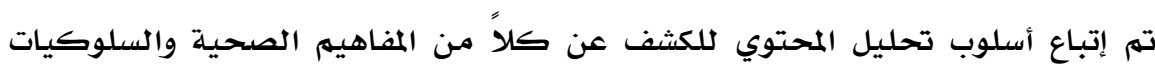

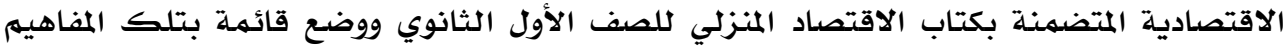

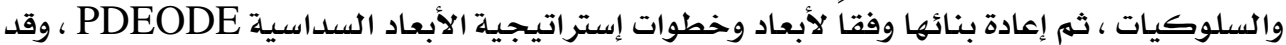

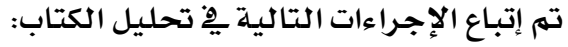

ا- تم قراءة محتوي كتاب الاقتصاد المنزلي للصف الأول الثانوي قراءة متأنية ودقيقة كلمهة كلمـة ، وجملة جملة ، وفقرة فقرة ، بإستثناء المقدمة والأسئلة والفهرس ؛ للإستدلالال علي الفي

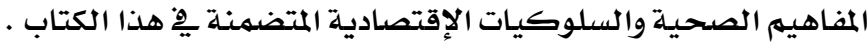

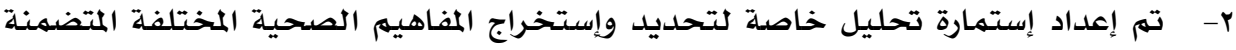

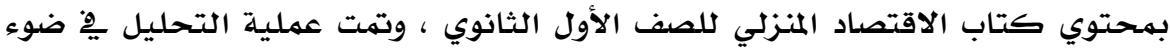

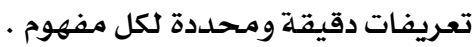

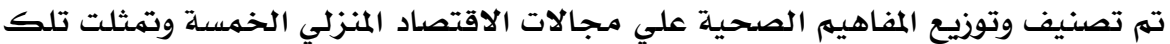

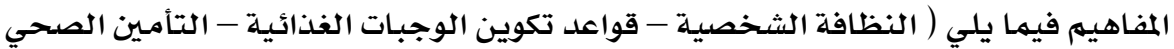

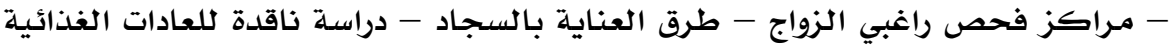

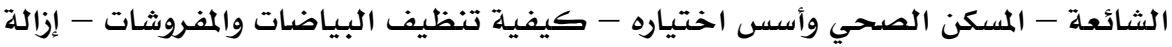

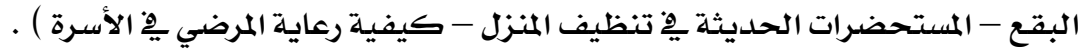

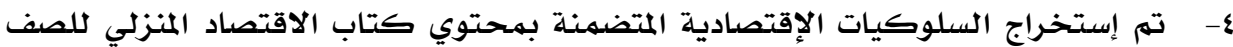

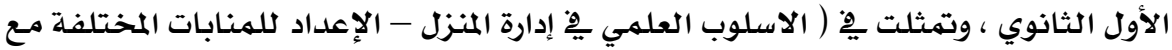

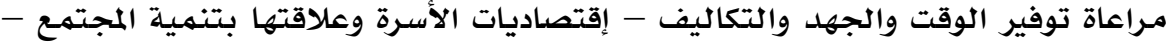

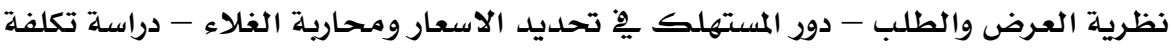

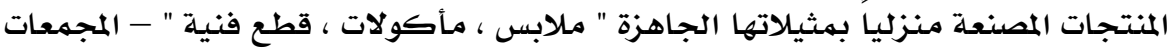

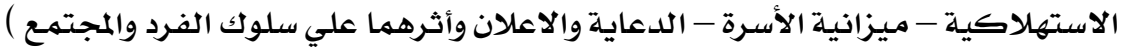
ه- حساب صدق وثبات التحليل كما يلي: 


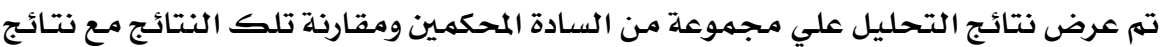

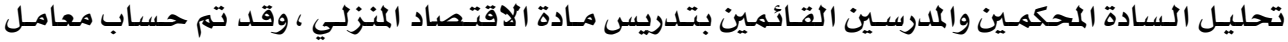
الاتفاق بين التحليلين باستخدام المعادلة الآتية : عـداد مـرات الاتفـاق

عدد مـرات الاتفاق + عدد مرات الاختلاف

وكان معامل الاتفاق = (^৭,V0) وهى قيمة مـرتفعة تدل على صدق التحليل .

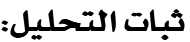

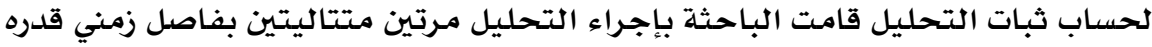

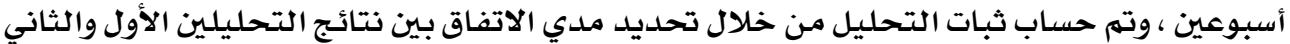

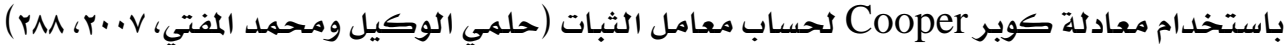

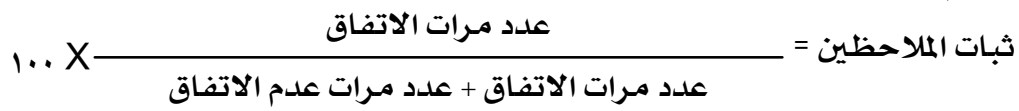

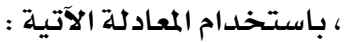

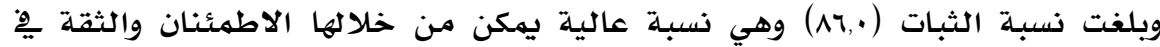

$$
\text { نتائج التحليل . }
$$

T- بعد التأكد من صدق وثبات التحليل تم عمل قائمهة لتوضيح تلك المفاهيم والسلوكيات

$$
\text { الاقتصادية. }
$$

ثDEODE ثانياً إعداد دليل معلمة الاقتصاد المنزلي للتدريس باستخدام إستراتيجية الأبعاد السداسية

ملحق (1)

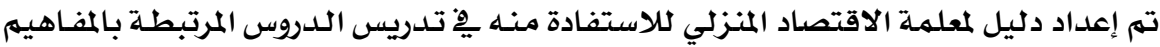

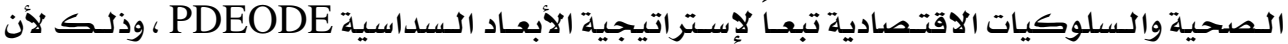

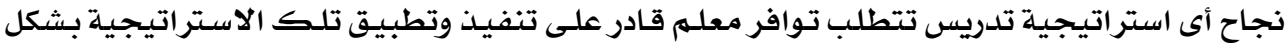

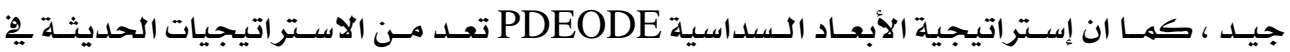

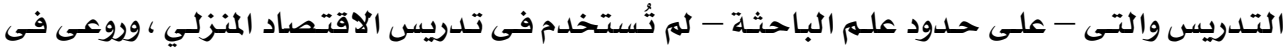

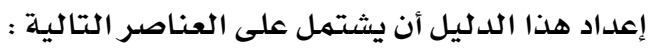

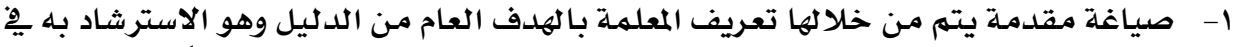

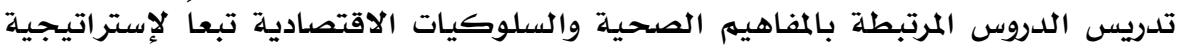

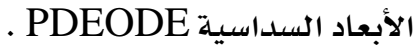

r- شرح مبسط لإستراتيجية الابعاد السداسية PDEODE. 


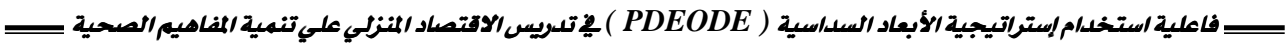
r- إرشادات وتوجيهات عامـة توضح دور المعلم عند إستخدام إستراتيجية الأبعاد السداسية • PDEODE ع- إعطاء مثال يوضتح كيفية تدريس أحد الدروس وفقا لخطوات إستراتيجية الابعاد السداسية . PDEODE

ضبط دليل المعلم :

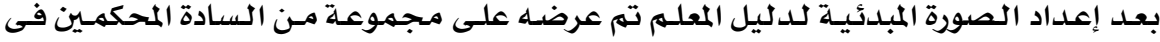
مجـال المناهـج وطرق التدريس للتعرف علي آرائهم ومـلاحظاتهم حول : ا- مدي صحة الدليل من الناحيتين اللغوية والعلميـة .

r- مدى كفاية محتويات الدليل من حيث الأهداف والوسائل التعليميلة والأنشطة المقترحة .

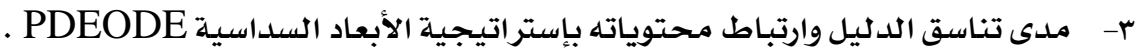

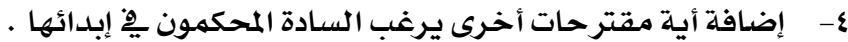
وبنـاءً علي آراء السـادة المحكهـين فى الـدليل تم إجـراء التعـديلات المطلوبـة، وكـان مـن أهمها إعادة صـياغة بعض الأهـداف ، وإضـافة بعض الأنشطة والأدوات التعليميـة ، وفيمـا عدا ذلك وجـد أن

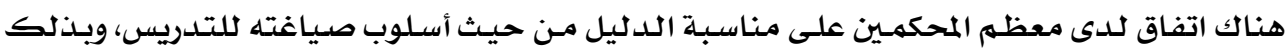
أصبـح دليل المعلم فى صورته النهائية وصالح للتطبيق .

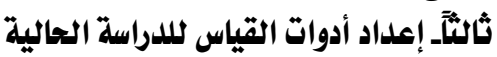
(ا (اختبار المفاهيي الصحية ( إعداد الباحثة )

تم اتبـاع الخطوات الآتيـة عند إعداد اختبـار المفاهيم الصحية أ- تحديد الهدف من الاختبار تم إعداد اختبـار تحصيلى معرفى للتعرف علي مدي إلمام الطالبـات عينـة الدراسـة للمفـاهيم

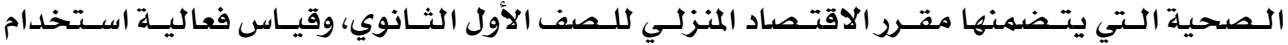

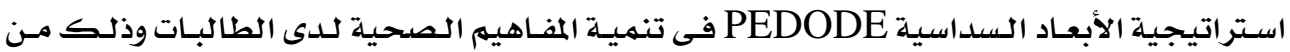
خلال مقارنة نتائج طالبـات المجموعتين ( الضابطة والتجريبية ) مِّ التطبيق البعدي للاختبـار. ب- عياغة مفردات الاختبار روعي عند صياغة مفردات الاختبـار أن تتسهم بالموضوعيـة بحيث لا تتأثر بذاتيـة المصحسح وأن تغطى معظم أهداف المنهج ، وتكونت مـن عدد ( . ) مفردة مـن نوع أسـئلة الصواب والخطـأ ، وعدد (10) مفردة مـن نوع أسئلة الاختيـار مـن متعدد تجيب عليها الطالبهة بوضـع دائرة حول رقم العبـارة التى تراهـا

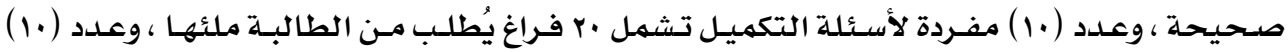

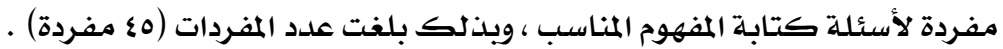
ج- - تحديد المستويات التى يقيسها الاختبار :

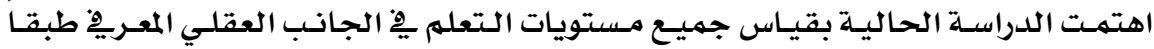
لتصنيف بلوم Bloom وهي ( التذكر - الفهم - التطبيق - التحليـل - التركيـب - التقويم ) ، 


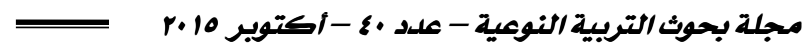

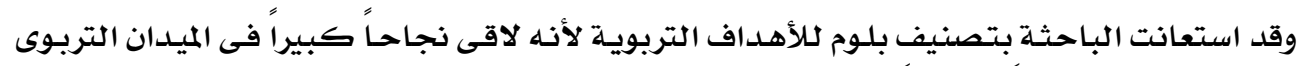

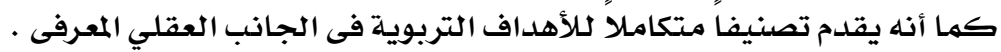
د- تعليمات الاختبار

وضع ِِّ بـاية الاختبار تعليمات عامـة توضح أهدافه ، وعدد الأسئلة وكيفية الإجابـة عنها،

وقد روعي عند صياغة تعليمات الاختبار ما يلي :

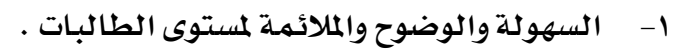

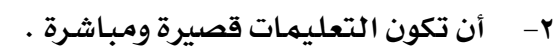

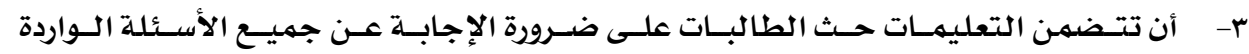

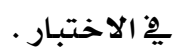

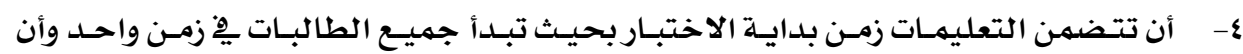

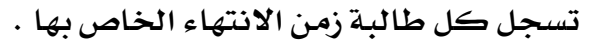

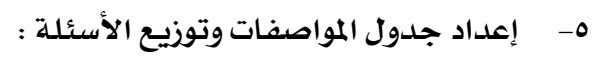

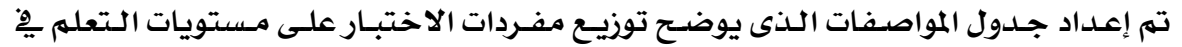

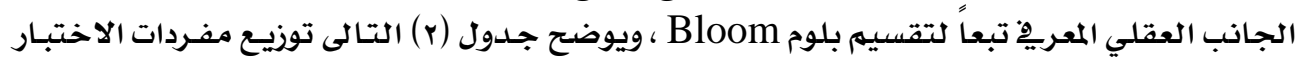

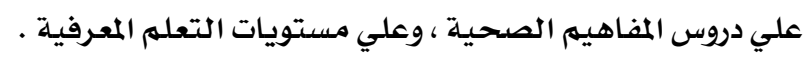

جدول (r)

توزيـع مفردات اختبار المفاهيه الصحية علي دروس المفاهيم الصحية ومستويات التعله المعرفية

\begin{tabular}{|c|c|c|c|c|c|c|c|c|c|}
\hline النسبي & الأسئلة مجموع & التقويه & التركيب & 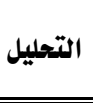 & التطبيق & الفهم & التذكر & دروس المفاهيي الصحية سية الصحية & 个 \\
\hline $7, \vee$ & $r$ & 1 & & & 1 & 1 & & النظافة الشخصية & 1 \\
\hline Ir,r & 9 & 1 & & 1 & r & 1 & 1 & قواعد تكوين الوجبات الفذائية & r \\
\hline $7, Y$ & $r$ & & & & 1 & 1 & 1 & التأمين الصحي & r \\
\hline $7, Y$ & $r$ & 1 & & 1 & 1 & & & مراكز فحص راغبي الزواج & $\varepsilon$ \\
\hline$\wedge, 9$ & $\varepsilon$ & & 1 & 1 & 1 & 1 & & تنظيف السجاد والعناية به & 0 \\
\hline Ir, r & 7 & $r$ & 1 & & 1 & $r$ & & العادات الفذائية الشائعة & 7 \\
\hline $11, \bullet$ & 0 & 1 & r & & 1 & 1 & & المنزل الصحي وأسس اختياره & $\checkmark$ \\
\hline$\wedge, 9$ & $\varepsilon$ & & 1 & 1 & 1 & 1 & & تنظيف البياضات والمفروشات & $\Lambda$ \\
\hline $7, Y$ & $r$ & & & & 1 & 1 & 1 & 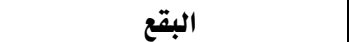 & 9 \\
\hline$\wedge, 9$ & $\varepsilon$ & 1 & 1 & & 1 & & 1 & مستحضرات تنظيف المنزل & 1. \\
\hline$\wedge, 9$ & $\xi$ & 1 & & & 1 & $r$ & & رعاية المرضي في الأسرة & 11 \\
\hline \multirow{2}{*}{$\% 1}$. & §o & $\wedge$ & 9 & $\varepsilon$ & ir & 11 & $\varepsilon$ & \multicolumn{2}{|l|}{ مجموع أسئلة كل مستوي } \\
\hline & & $I V, \Lambda$ & r & $\wedge, 9$ & $r q, V$ & $r \xi, \xi$ & $\wedge, 9$ & \multicolumn{2}{|l|}{ النسبة المئوية } \\
\hline
\end{tabular}




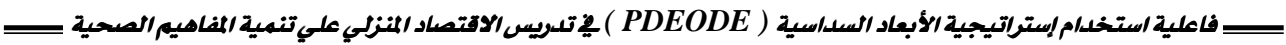
و- نظام تقدير الدرجات وطريقة تصحيح الاختبار

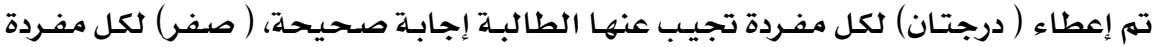

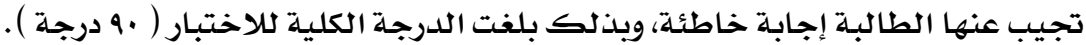

ز- إجراء التجرية الاستطلاعية لاختبار المفاهيم الصحية

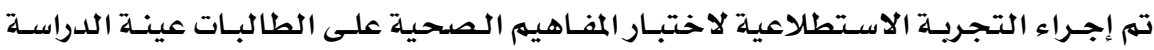

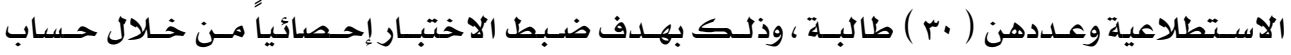

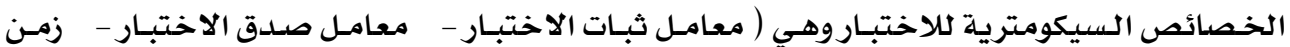

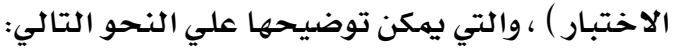

- - حساب معامل ثبات الاختبار

Kuder تمم استخدام طريقة تحليل التباين من خلال تطبيق معادلة كيودر وريتشاردسون الاحتيار ( Richardson 20

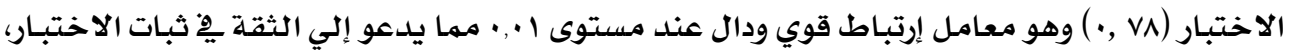

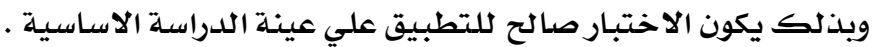

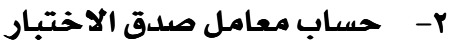

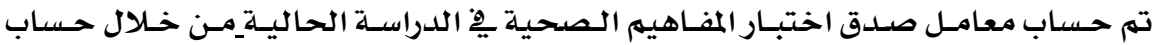
كلاً من:

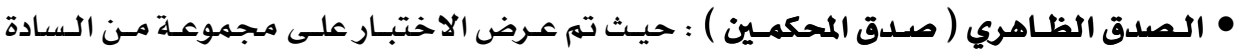

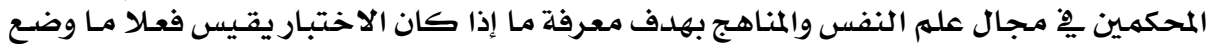

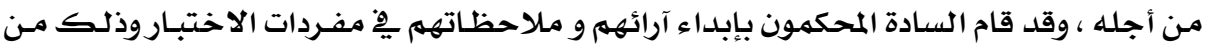

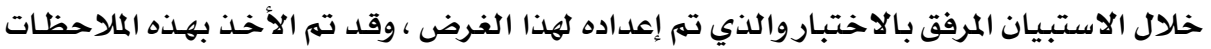

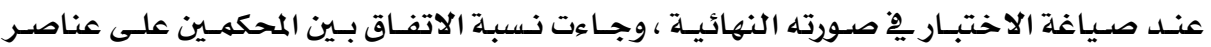

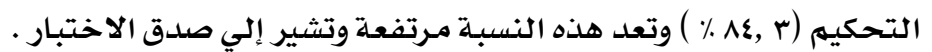

• الصلدق الذاتي : وذلك بحساب الجذر التربيعى لمعامل ثبات الاختبار ويلغت

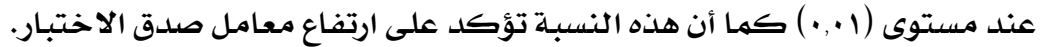

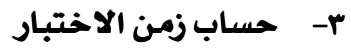

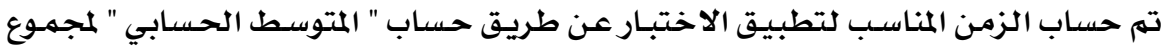

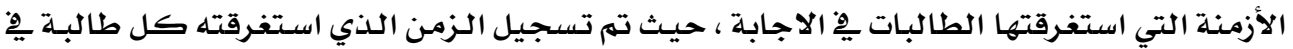

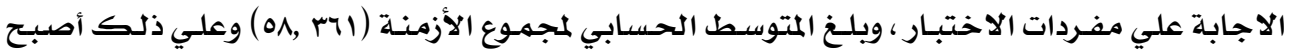
زمن الاختبار (•r) دقيقة مفردات الاحتبار 
ح- إعداد مفتاح تصحيح اختبار المفاهيم الصحية

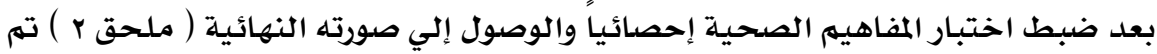

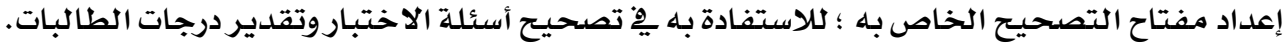

(ץ) مقياس السلوكيات الاقتصادية ( إعداد الباحثة ) .

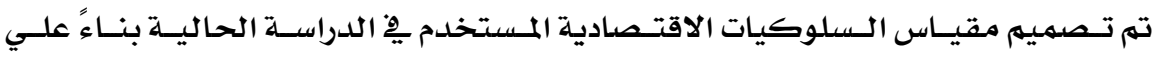

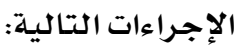

أ- الاطلاع علي علدد من البحوث العربية والأجنبية التي تناولت السلوكيات الاقتصادية المختلفة

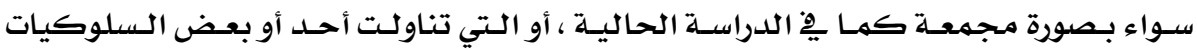

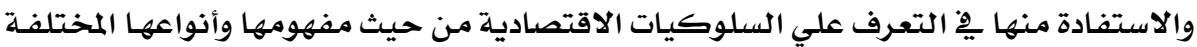

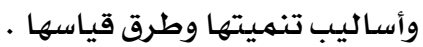

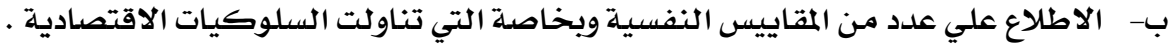

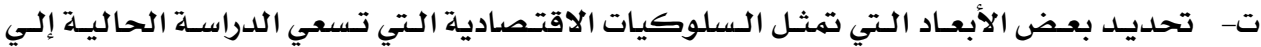

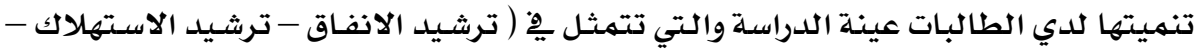

$$
\text { مهارات وفنون الشراء - تخطيط الميزانية - الادخار ) . }
$$

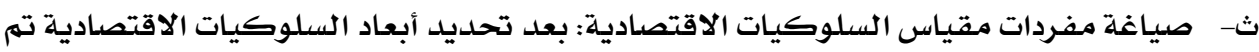

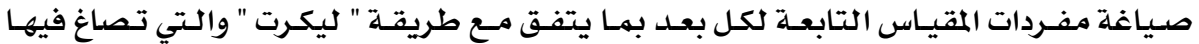

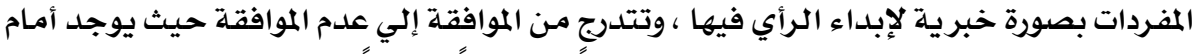

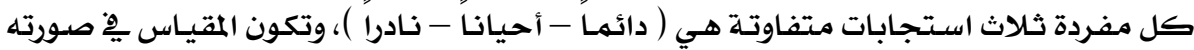

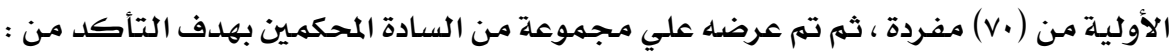

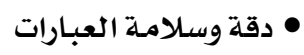

$$
\begin{aligned}
& \text { • مدي انتماء كل عبارة للبعد المضوعة بـه . }
\end{aligned}
$$

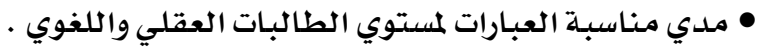

$$
\begin{aligned}
& \text { • تعديل أو حذف أو إضافة بعض العبارات العبارات المبات العبات }
\end{aligned}
$$

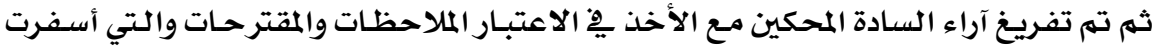

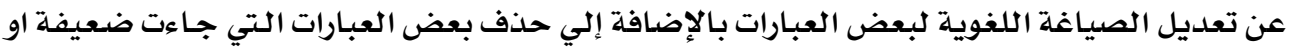

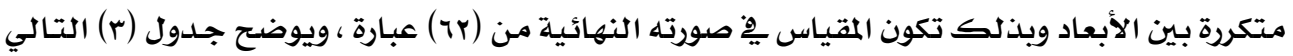

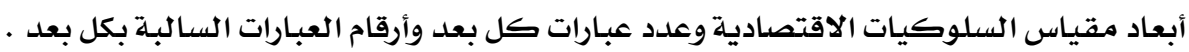




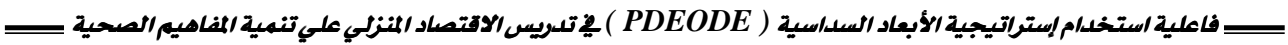

جدول (r) (r) (a)

أبعاد مقياس السلوكيات الاقتصسادية وأرقام العبارات الموجبـة والسـالبـة التابعـة لكل بعد

\begin{tabular}{|c|c|c|c|}
\hline المجموع & أرقام العبارات السالبة & عدد العبارات وأرقامها & أبعاد السلوكيات الاقتصادية \\
\hline ir & - & $(\operatorname{lr}-1) \mathrm{Ir}$ & ترشيد الاستهلاك \\
\hline ir & rE-1A_17 & $\left(r O_{-} \mid I^{\prime}\right)$ Ir & ترشيد الانفاق \\
\hline $1 \varepsilon$ & $r \Lambda_{-}+r_{-}-r a$ & $\left(r a \_r q\right)^{1 \varepsilon}$ & مهارات وفنون الشراء \\
\hline ir & 01 & (01 & تخطيط الميزانية \\
\hline ir & 91 .09_Or & $($ Tr_or $)$ Ir & 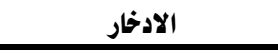 \\
\hline \multicolumn{3}{|c|}{ r Tr عبارة ( or عبارة إيجابية + • 1 عبارة سلبية ) } & مجموع العبارات \\
\hline
\end{tabular}

ج- إجراء التجريسة الاستطلاعية لمقياس السلوكيات الاقتصادية:

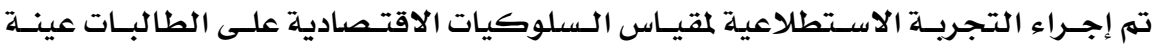

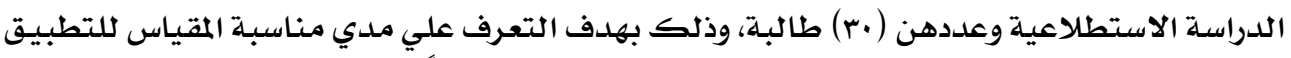

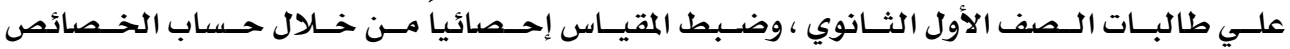

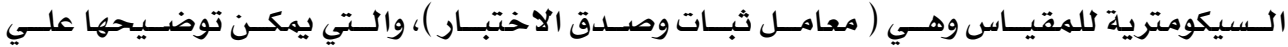

النحو التالي:

\section{• حساب معامل ثبات مقياس السلوكيات الاقتصادية:}

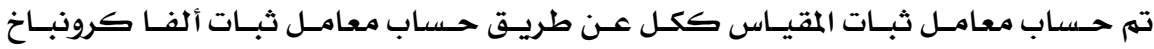

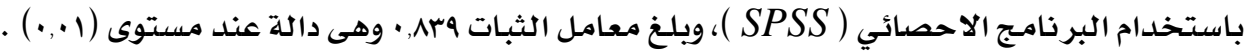

\section{• حساب معامل صلدق مقياس السلوكيات الاقتصادية :}

تم التأكد مـن صدق مقيـاس السلوكيات الاقتصادية المستخدم فِّ الدراسـة الحاليـة عن

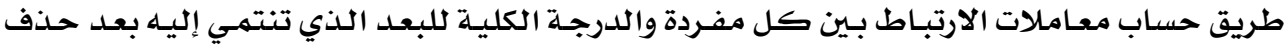

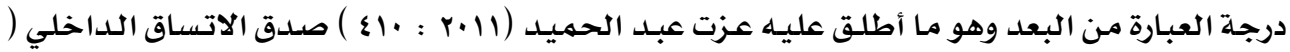

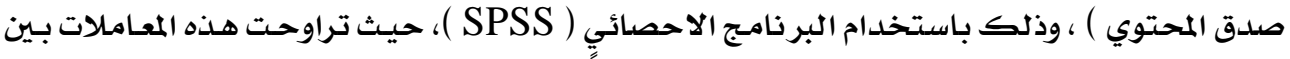

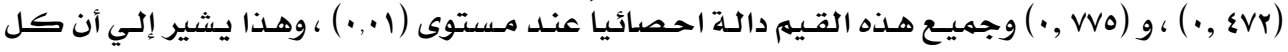

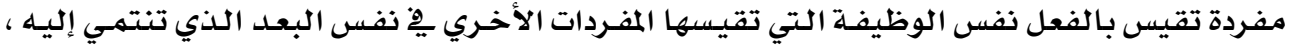

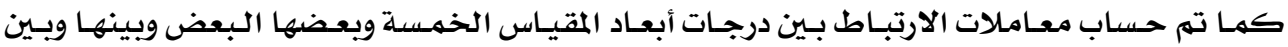

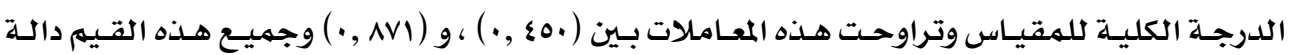

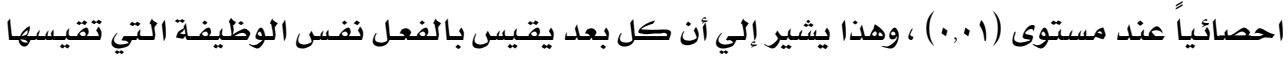

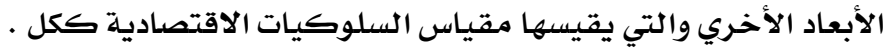
بعد حساب معامل ثبات وصدق مقياس السلوكيات الاقتصادية ، اطمأنت الباحثة إلى الى

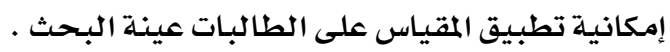


خامساً_ الإعداد لتجربة الدراسة النهائية وتنفيذها :

$$
\begin{aligned}
& \text { تم تنفيذ تجربة الدراسة الحالية على عدة مراحل هي: } \\
& \text { (1) تحديد الهدف من تجرية الدراسة }
\end{aligned}
$$

هدفت تجرية الدراسلة الحالية إلى التعرف علي فاعلية إستخدام استراتيجية الأبعاد

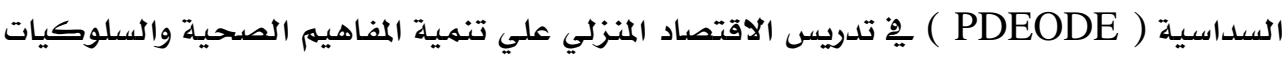
الاقتصدادية لدي طالبـات الصف الأول الثانوي .

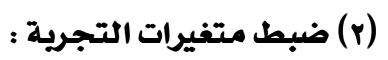

تم ضبط بعض المتغيرات التى يمكن أن تؤثر على نتائج التجرية وذلك للتحقق من تجانس

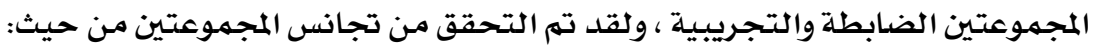

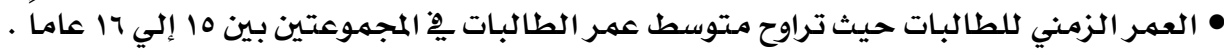

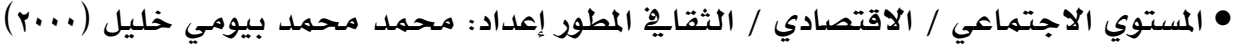

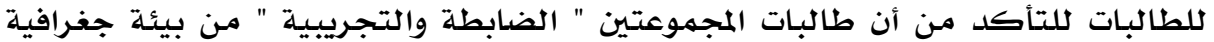
وإجتماعية واحدة ومتكافئتين يِّ المستوي الاجتماعي والاقتصادي والثقايفٍ ؛ حتي لا يؤثر عدم

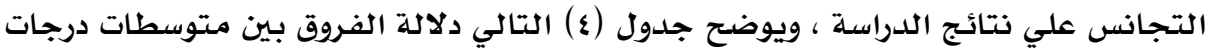

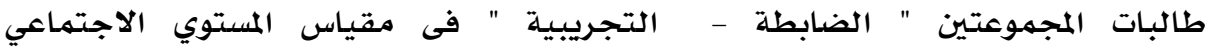

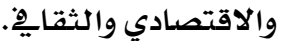

\section{جدول (६) ( )}

\begin{tabular}{|c|c|c|c|c|c|c|}
\hline الدلالة الإحصائية & قيمة (ت) & $(\varepsilon)$ & ( $\mathbf{P})$ & (j) & المجموعة & المتفير \\
\hline \multirow{2}{*}{ غند أى مستوى دال } & $\multirow{2}{*}{0}, 1$ & $01, r$ & $\wedge, \xi \cdot$ & 7. & الضابطة & \multirow[t]{2}{*}{ إجتماعي } \\
\hline & & $\varepsilon \cdot, r$ & $7, \$ 1$ & 7. & التجريبية & \\
\hline \multirow{2}{*}{ غير دال } & \multirow{2}{*}{ rqA," } & $0 \Lambda, r$ & 19,9v & 7. & الضابطة & \multirow[t]{2}{*}{ إقتصادي } \\
\hline & & $\bullet \wedge, \varepsilon$ & $91,9 \mathrm{~V}$ & 7. & التجريبية & \\
\hline \multirow{2}{*}{ غند غير دال مندئ مستوى } & \multirow{2}{*}{$\cdot \wedge 0,1$} & $70, r$ & $r, A r$ & 7. & الضابطة & \multirow[t]{2}{*}{ ثقافي } \\
\hline & & $r r, r$ & $\Lambda, \wedge r$ & 7. & التجريبية & \\
\hline \multirow{2}{*}{ غير دال } & \multirow{2}{*}{$\xi \bullet \cdot}$, & $.7,17$ & A9, rYI & 7. & الضابطة & \multirow[t]{2}{*}{ الدرجة الكلية } \\
\hline & & ri,ls & $\cdot 1, r r r$ & 7. & التجريبية & \\
\hline
\end{tabular}

دلالة الفروق بين متوسطات درجات طالبـات المجموعتين

" الضابطة - التجريبية " فى مقياس المستوي الاجتماعي والاقتصسادي والثقايِ 


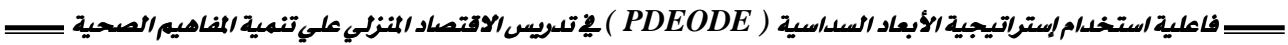
يتضح من جدول (ع) عدم وجود فروق دالة إحصائيا بين متوسطات درجات المجموعتين "

الضابطة - التجريبية" هِ المستوى الاجتماعي / الاقتصادي / الثقايٍ حيث كانت قيم " ت " المحسوبـة أقل من قيم " ت " الجدولية عند درجة حرية (111) عند أي مستوى من مستويات الدلالة ، وهذا يدل على تجانس المجموعتين يِّ هذا المتغير .

• التأكد من تكافؤ المجموعتين ( الضابطة والتجريبية ) فِ التطبيق القبلي لأدوات الدراسـة والمتمثلة يخ اختبـار المفاهيه الصحية ، ومقيـاس السلوكيات الاقتصادية ، وأسفرت النتائج عن عدم وجود فروق ذات دلادة إحصائية بين المجموعتين كما هو موضح بكلا من جدول (0) ، : (7) التتاليين

\section{جلدول (0)}

قيهمة " ت " ودلالتها الاحصائية بين متوسطي درجات طالبـات

المجموعتين " الضـابطة ـ التجريبيـة " في التطبيق القبلى لاختبـار المفاهيه الصحية

\begin{tabular}{|c|c|c|c|c|c|}
\hline الدلالة الإحصائية & قيمة (ت) & $(\varepsilon)$ & ( $P$ ) & (j) & المجموعة \\
\hline \multirow{2}{*}{ غند أى مستوى دال } & \multirow{2}{*}{ IVr, } & \&ro,o & Irr,os & 9. & الضابطة \\
\hline & & $i v \wedge, 0$ & $97 \checkmark, 0 \xi$ & 7. & التجريبية \\
\hline
\end{tabular}

يتضح من جلدول (0) السـابق أن هنالك تكافؤ بين طالبـات مجموعتي الدراسـة " الضابطة .

التجريبية " يْ متوسط الدرجات يخ التطبيق القبلي لاختبـار المفاهيه الصحية ، حيث كانت قيمة " ت " المحسوبة (YVI , •) ، وهى أقل من قيهـة " ت " الجدولية عند درجة حرية (111) عند أي مستوى مـن مستويات الدلالهة .

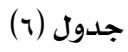

قيمة " ت " ودلالتها الاحصائية بين متوسطات درجات طالبـات

المجموعتين " الضـابطة ـ التجريبية " في التطبيق القبلى لمقياس السلوكيات الاقتصادية

\begin{tabular}{|c|c|c|c|c|c|c|c|c|}
\hline \multirow{2}{*}{ الدلالة الإحصائية } & \multirow{2}{*}{ قيمة (ت) } & \multicolumn{3}{|c|}{ التجريبية } & \multicolumn{3}{|c|}{ الضابطة } & \multirow{2}{*}{ 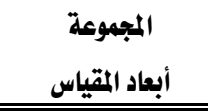 } \\
\hline & & $(\varepsilon)$ & $(\boldsymbol{\beta})$ & (j) & $(\varepsilon)$ & $(\boldsymbol{\beta})$ & (j) & \\
\hline غير دالة & $\cdot v v, \cdot$ & $\| 1 v, 1$ & ro.,11 & \multirow{6}{*}{9.} & $r\{\Lambda, I$ & rq & \multirow{6}{*}{7.} & ترشيد الانفاق \\
\hline غير دالة & $.0\}$, & VIA, 1 & VIV,Ir & & $7 \vee 7,1$ & Vrr,ir & & ترشيد الاستهلاك \\
\hline غير دالة & $171, \cdot$ & $1 \cdot r, 1$ & ro., l. & & 170,1 & rAT,l. & & مهارات وفنوز الشراء \\
\hline غير دالة & IIr, & $\Delta \wedge \wedge, 1$ & $50 \cdot, 1\}$ & & $9 r 1,1$ & $\{A r, I r$ & & تخطيط الميزانية \\
\hline غير دالة & 179, & $.97,1$ & $\mid r \wedge, \|$ & & $.09,1$ & riv,ll & & الادخار \\
\hline غير دالة & r.६,, & orq,r & $\cdot 0 \cdot, 01$ & & $\eta \leqslant r, r$ & $\mid A T, \Delta \Lambda$ & & الدرجة الكلية \\
\hline
\end{tabular}


يتضح من جدول (ج) السـابق أن هناك تكافؤ بين طالبات مجموعتي الدراسـة " الضابطة .

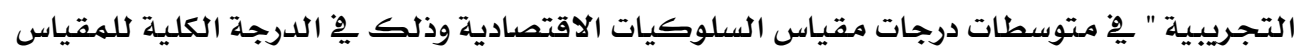

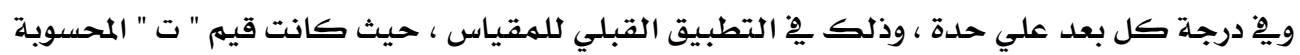

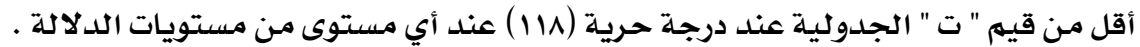

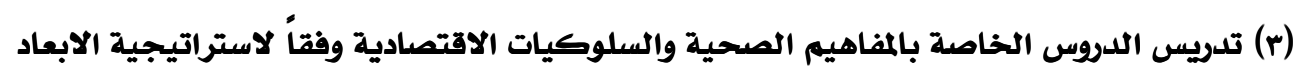
السداسية PEDODE:

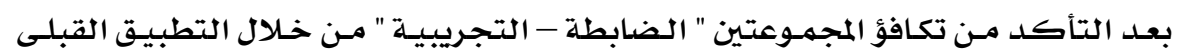

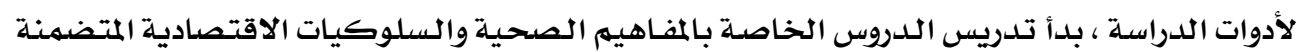

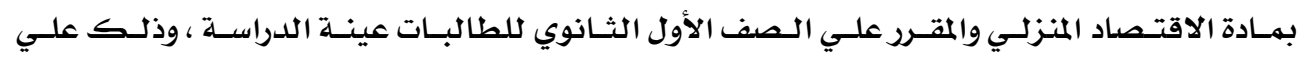

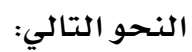

- المجموعة الضابطة : تم التدريس باستخدام الطريقة التقليدية والمعتاد استخدامها .

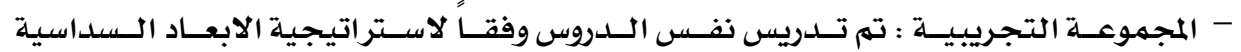
PEDODE وبالاستعانة بدليل المعلهم.

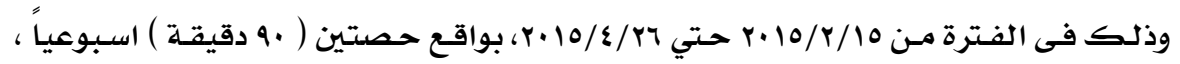

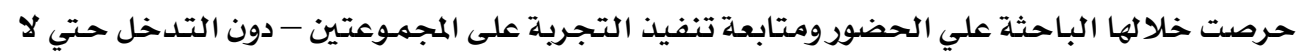

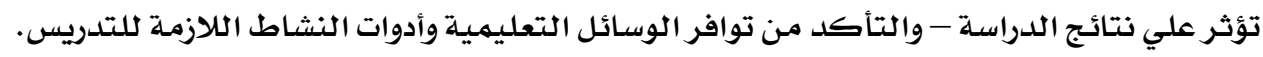

(ع) التطبيق البعدى لأدوات الدراسة:

بعد الانتهاء من تدريس الدروس الخاصة بالمفاهيم الصحية والسلوكيات الاقتصادية

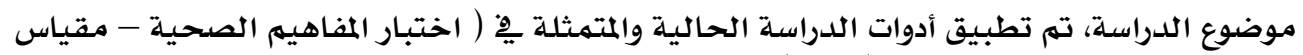

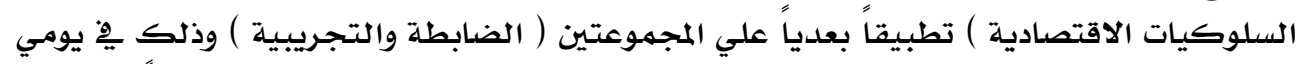

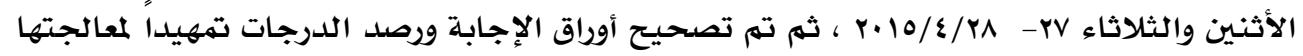

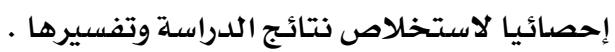
(0) المعالجة الإحصائية

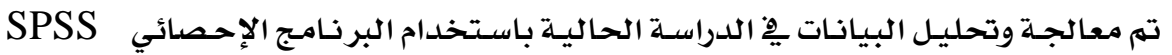
Version 20.0

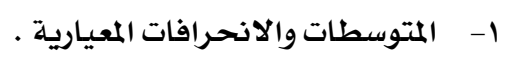

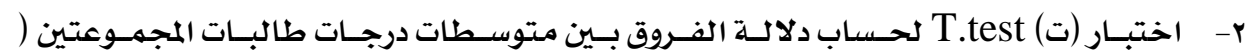

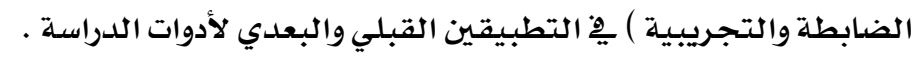

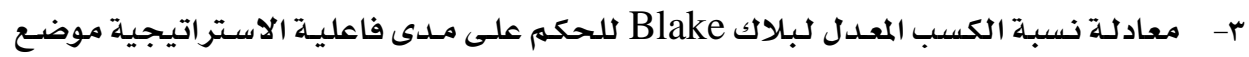

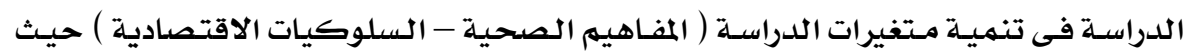




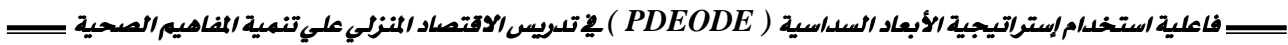
تعتهـــ هـــه المعادلـة علـى الفـروق فـى مـتوسـطى الـدرجات بـين التطبيـق القبلـى والتطبيـق البعدى لأفراد مجموعة الدراسـة ،وتم حسـابها يدوياً من خلال المعادلة:

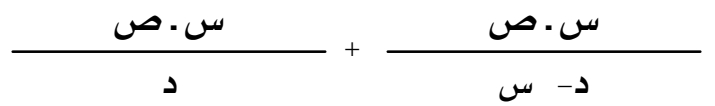

$$
\begin{aligned}
& \text { حيث س = المتوسط الحسبابي للمسجموعة يِّ القياس البعدي } \\
& \text { ص= المتوسط الحسـابي للمهجموعة يِّ القياس القبلي } \\
& \text { د = الدرجـة النهائية العظمى للمقياس }
\end{aligned}
$$

سادساً:_ تقائج اللدراسة وتفسيرها دهي (1) نتائج الفرض الأول

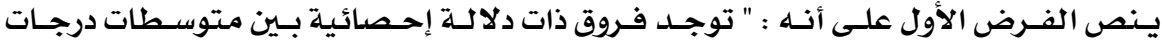
طالبـات المجموعتين " الضـابطة - التجريبيـة " لاختبـار المفـاهيم الصحية يخ التطبيـق البعدي لصدالح

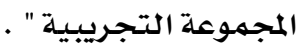

وللتحقق من صححة هذا الفرض تم استخدام اختبار( ت ) T. test متوسطات درجات طالبـات مجموعتي الدراسـة " الضابطة - التجريبية " فى التطبيق البعدى لاختبار المفاهيم الصحية المعد خصيصا لهذا الغرض وذلك فِ الدرجة الكلية للاختبـار ،ويْ درجة المفاهيم الصحية التابعة لكل مـجال مـن مـجالات الاقتصداد المنزلي علي حدة ، وتم إجراء المعالجات الإحصائية بـاستخدام برنامـج ) SPSS Ver 20.0 )

$$
\text { (v) جدول) }
$$

\begin{tabular}{|c|c|c|c|c|c|c|c|c|}
\hline \multirow{2}{*}{ الإحصائية } & \multirow{2}{*}{ قيمة (ت) } & \multicolumn{3}{|c|}{ التجريبية } & \multicolumn{3}{|c|}{ الضابطة } & \multirow{2}{*}{ 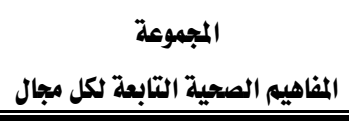 } \\
\hline & & $(\varepsilon)$ & ( $\boldsymbol{P})$ & (j) & $(\varepsilon)$ & $(\boldsymbol{P})$ & (j) & \\
\hline دالة عند (1•,•) & $\cdot 1 \cdot, r r$ & $71 \leqslant, 1$ & $A \cdots, 19$ & \multirow{6}{*}{7.} & 179,1 & VAr,Ir & \multirow{6}{*}{7.} & الفذاء والتفذية \\
\hline دالة عند (ا•,•) & rqv, 17 & $11 \wedge, r$ & $07 v, I V$ & & $\{99,1$ & •Ar,Ir & & الملابس والنسيج \\
\hline دالة عند (ا•,•) & $7 \vee \wedge, 9$ & $0 \leqslant 9, \xi$ & $7 \wedge r, 1 \wedge$ & & $0 \Lambda \cdot, 1$ & $77 \mathrm{~V}, 1 \mathrm{~T}$ & & إدارة المنزل \\
\hline دالة عند (1+, •) & $\$ 1 \cdot, 1 r$ & ror,r & rIV,IN & & $\leqslant 7 \vee, 1$ & $0 \cdot \cdot, 1 r$ & & الأمومة والطفولة والعلاقات الأسرية \\
\hline |دالة عند (ا•,•) & rIT,IV & Tro,r & $\cdot 7 r, r \cdot$ & & $71 \varepsilon, 1$ & $r \cdot \cdot, r$ & & تأثيث وتنسيق المسكن \\
\hline |دالة عند (ا•,•) & rาฯ, ז\& & $V \leqslant r, 0$ & rrr, १६ & & $.07, \xi$ & rrr, Tr & & الدرجة الكلية لاختبار \\
\hline
\end{tabular}

قيمـة " ت " ودلالتها الاحصائية بين متوسطات درجات طالبـات

المجموعتين " الضـابطة ـ التجريبية " في التطبيق البعدي لاختبـار المفاهيم الصحية

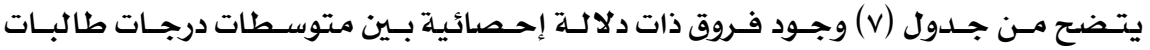
المجموعتين " الضـابطة - التجريبية " يِ التطبيق البعدي لاختبار المفاهيم الصحية لصالح المجموعـة 


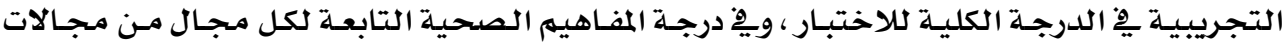

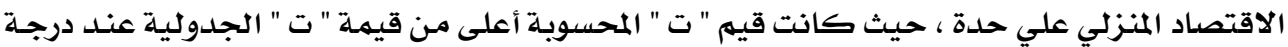

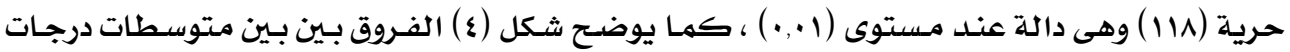

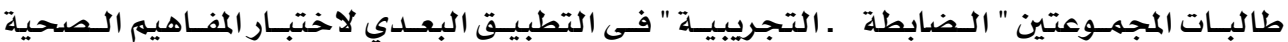

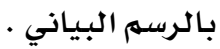

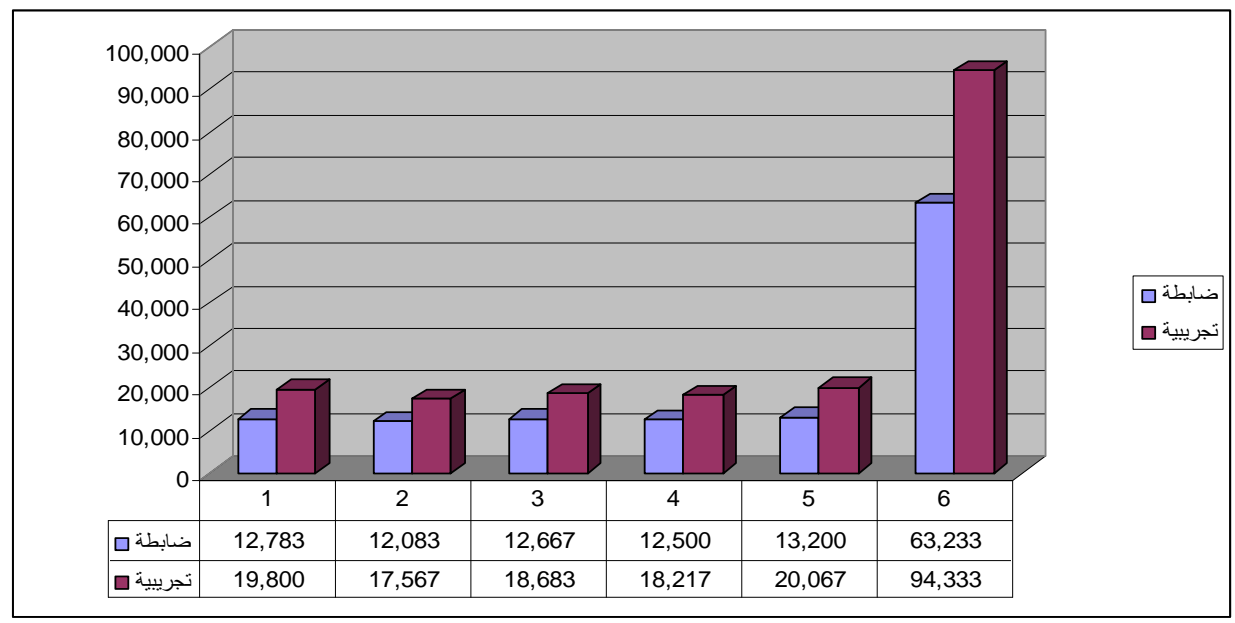

شكل (६)

الفروق بين بين متوسطات درجات طالبات المجموعتين

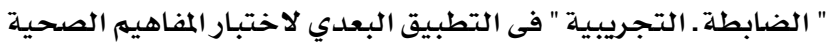

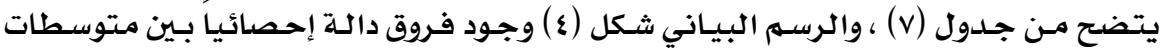

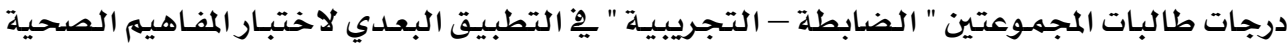

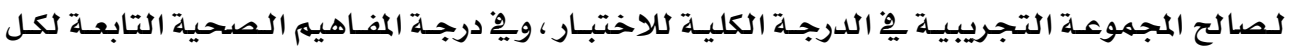

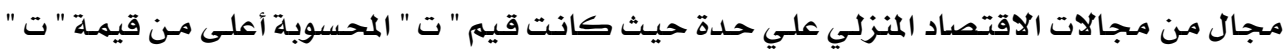

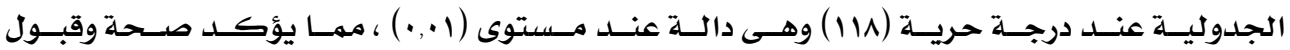

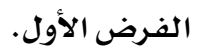

\section{(Y) نتائح الفرض الثاني}

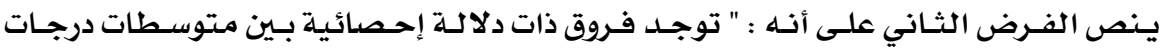

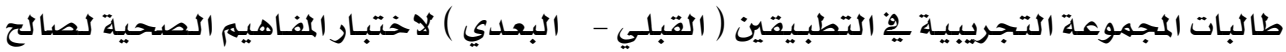

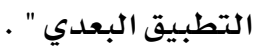

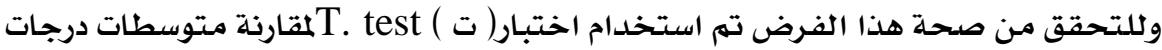

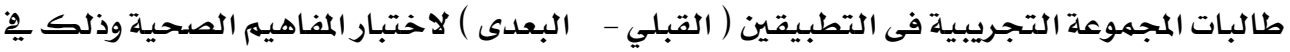

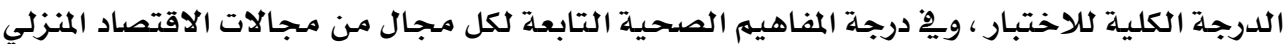




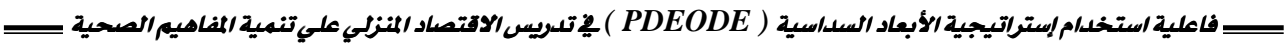
علي حدة ، وتم إجراء المعالجـات الإحصائية بـاستخدام برنامـج( SPSS Ver 20.0 ) كمها يتضح من خلال جدول (^) التالي:

جدول (^)

قيمة " ت " ودلالتها الاحصائية بـين متوسطات درجات طالبـات

المجموعتين " الضـابطة ـ التجريبيـة " في التطبيق البعدي لاختبـار المفاهيم الصحية

\begin{tabular}{|c|c|c|c|c|c|c|}
\hline الدلالة الإحصائية & قيمة (ت) & $(\varepsilon)$ & $(\boldsymbol{P})$ & (j) & التطبيق & المقاهيم الصحية \\
\hline \multirow{2}{*}{ دالة عند ا•,• } & \multirow{2}{*}{ rq, Trr } & $1, \cdot r r$ & 1.,9rr & 7. & القبلي & \multirow[t]{2}{*}{ الغذاء والتفذية } \\
\hline & & $1,71 \varepsilon$ & $19,1 \cdots$ & 9. & البعدى & \\
\hline \multirow{2}{*}{ دالة عند ا+,• } & \multirow{2}{*}{$r \cdot, A r A$} & $1,89 r$ & $11,1 \ldots$ & 9. & القبلي & \multirow[t]{2}{*}{ الملابس والنسيج } \\
\hline & & $r, 11 \wedge$ & IV,OTV & 7. & البعدى & \\
\hline \multirow{2}{*}{ دالة عند ا+,• } & \multirow{2}{*}{$1 \cdot, 7 \wedge A$} & I, rAY & $11, \cdot 1 \mathrm{~V}$ & 7. & القبلي & \multirow[t]{2}{*}{ إدارة المنزل } \\
\hline & & $\leqslant, 0 \leqslant 9$ & IA, TAr & 7. & البعلى & \\
\hline \multirow{2}{*}{ دالة عند ا•,• } & \multirow{2}{*}{$1 \wedge, 11 \%$} & $1, \cdot r r$ & $1 \cdot, 90$ & 7. & القبلي & \multirow{2}{*}{ الأمومة والطفولة والعلاقات } \\
\hline & & r, ror & IA, rIV & 7. & البعلى & \\
\hline \multirow{2}{*}{ دالة عند ا•,• } & \multirow{2}{*}{$\leqslant 0,19$. } & $1, \cdot 0 V$ & $1 ., 97 \mathrm{~V}$ & 7. & القبلي & \multirow[t]{2}{*}{ تاثيث وتنسيق المسكن } \\
\hline & & r, tro & $r \cdot, \cdot 7 r$ & 7. & البعلى & \\
\hline \multirow{2}{*}{ دالة عند ا+,• } & \multirow{2}{*}{ ro, rm } & $0,1 \vee \wedge$ & $0 \xi, 97 \mathrm{~V}$ & 7. & القبلي & \multirow[t]{2}{*}{ اللدرجة الكلية للاختبار } \\
\hline & & $0, Y \leqslant Y$ & Q६, rrr & 7. & البعلدى & \\
\hline
\end{tabular}

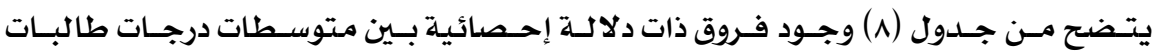

المجموعة التجريبية يخ التطبيقين" القبلي - البعـدي " لاختبـار المفاهيم الصحية لصسالح التطبيق

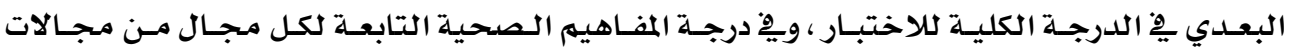

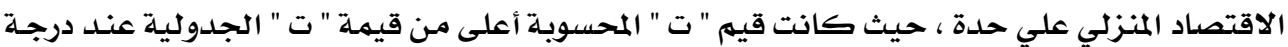

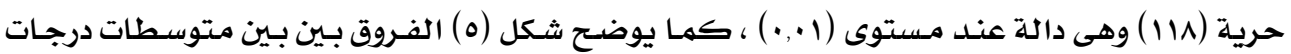

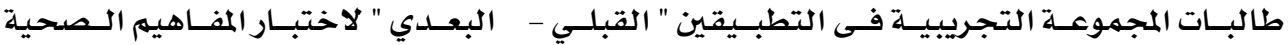
بالرسهم البياني . 


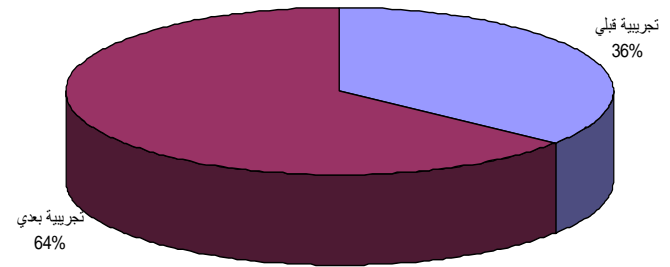

شكل (ه)

الفروق بين متوسطات درجات طالبات المجموعة

التجريبية فى التطبيقين " القبلي - البعدي " لاختبار المفاهيم الصحية

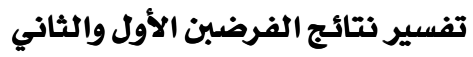

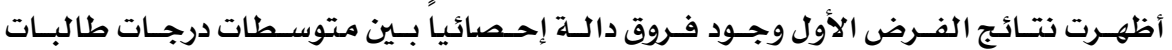

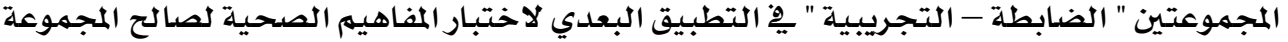

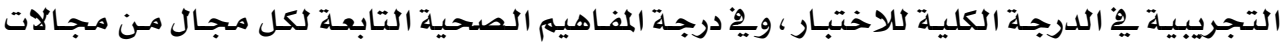
الاقتصاد المنزبي علي حدة .

وأظهرت نتائج الفرض الثاني وجود فروق ذات دلالة إحصائية بين متوسطات درجـات طالبـات

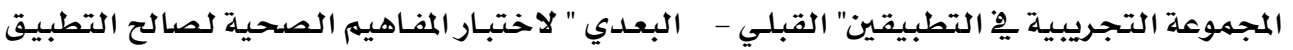

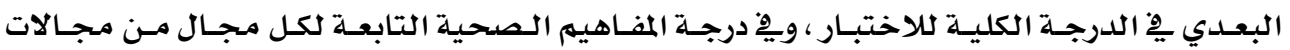

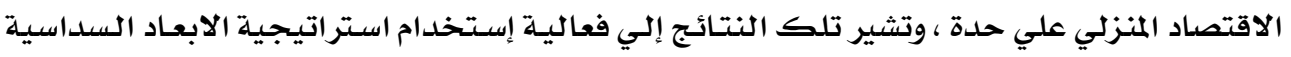
PDEODE

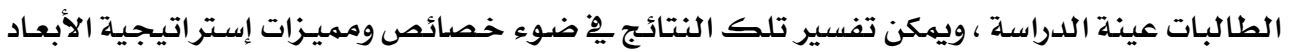

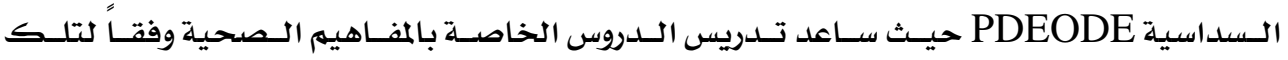

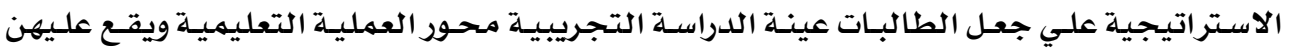

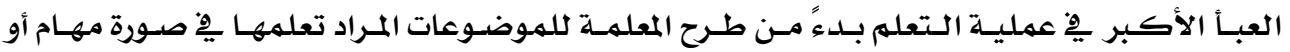

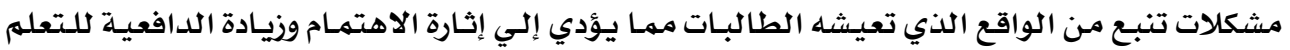

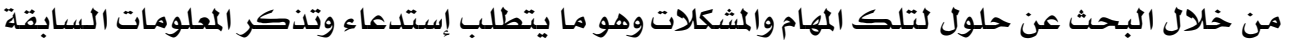

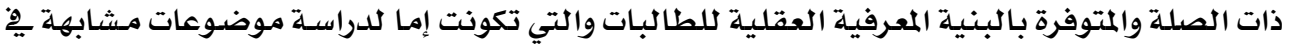

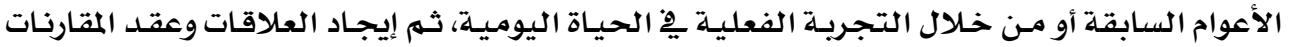

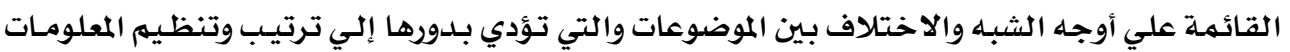

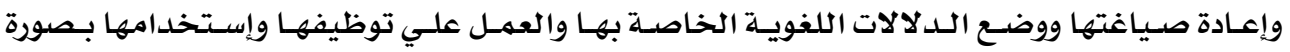

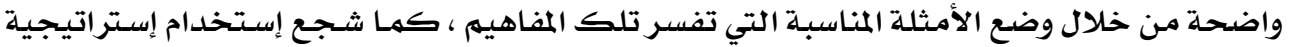

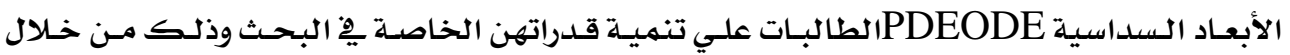

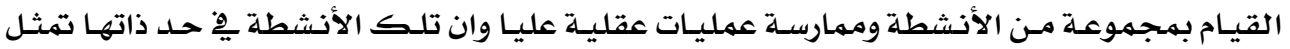




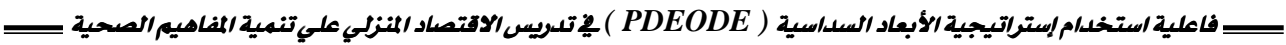
خطوات إستراتيجية الأبعاد السداسية PDEODE حيث تقوم الطالبـات بالمناقشة والتفسير والتنبؤ

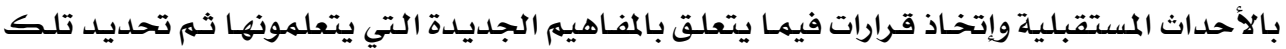

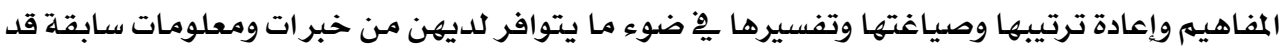

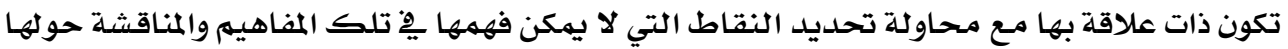

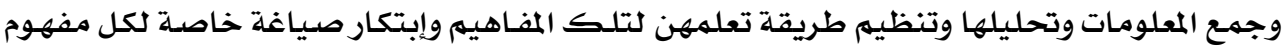

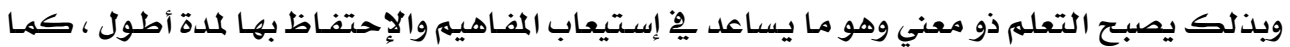

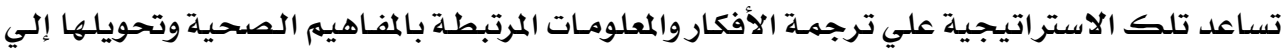

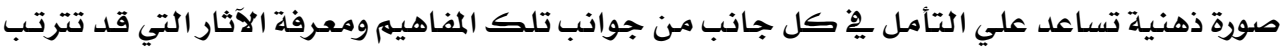

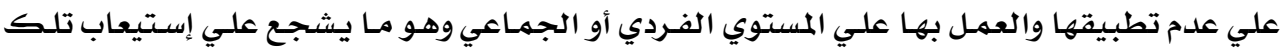

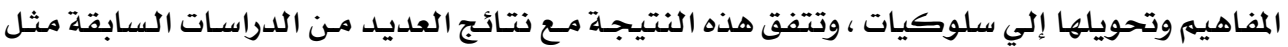

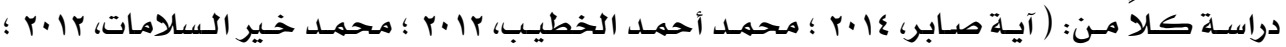

( Kolari \&Ranne, 2005 ; Costu, 2008

: (r) نتئج الفرض الثالث:

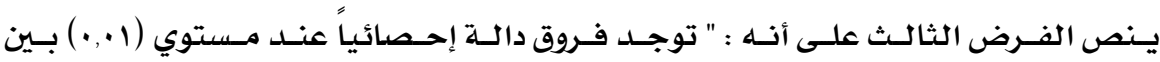

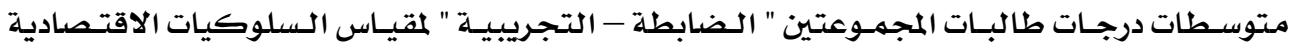

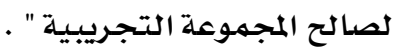

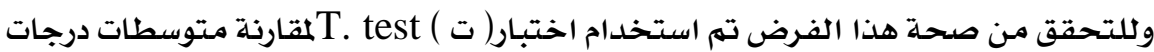

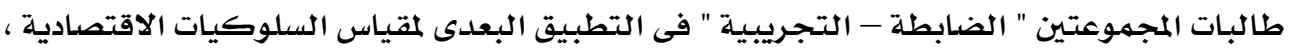

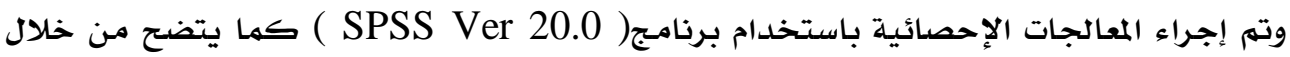

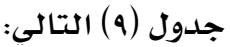

\section{جدول (q)}

قيمة " ت " ود لالتها الاحصائية بين متوسطات درجات طالبات

المجموعتين " الضابطة ـ التجريبيـة " في التطبيق البعدي لمقياس السلوكيات الاقتصسادية لوحية

\begin{tabular}{|c|c|c|c|c|c|c|c|c|}
\hline \multirow{2}{*}{ الإحصائية } & \multirow{2}{*}{ قيمة } & \multicolumn{3}{|c|}{ التجريبية } & \multicolumn{3}{|c|}{ الضابطة } & \multirow{2}{*}{ 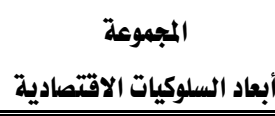 } \\
\hline & & $(\varepsilon)$ & ( $\boldsymbol{P})$ & (j) & $(\varepsilon)$ & ( $\boldsymbol{(})$ & (j) & \\
\hline دالة عند (ا+,•) & q.r, ir & $r 0 ., 1$ & $r \cdot \cdot, r r$ & \multirow{6}{*}{. } & $991, r$ & $7 \cdots, 10$ & \multirow{6}{*}{7.} & ترشيد الاستهلاك \\
\hline دالة عند (ا+,•) & $1 \cdot 9,10$ & $\| v, 1$ & ro., rl & & rAq,r & - $7 v, 1 \varepsilon$ & & ترشيد الانفاق \\
\hline دالة عند (ا+,•) & $\cdot \wedge 9,1 r$ & l.r,r & MAr,Yr & & r£o,६ & $70 \cdot, 1 \varepsilon$ & & فتوز الشراء \\
\hline دالة عند (ا+,•) & 991,17 & 711,1 & $\cdot 0, r r$ & & ovi,r & AAr,Ir & & تخطيط الميزانية \\
\hline دالة عند (ا•,•) & $77 r, 19$ & $r \leqslant q, 1$ & $77 v, 11$ & & •vq, r & rAT,IT & & الادخار \\
\hline دالة عند (ا•,•) & $9 \wedge \Lambda, r v$ & $0 \wedge 7, r$ & $\{0 \cdot, 1 \cdot 1$ & & Arı, 7 & oAr, $\mathrm{V}$. & & اللدرجة الكلية \\
\hline
\end{tabular}


يتضح من جدول (ه) وجود فروق ذات دلالة إحصائية بين متوسطات درجات طالبات

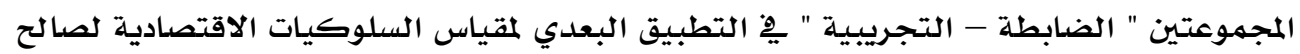

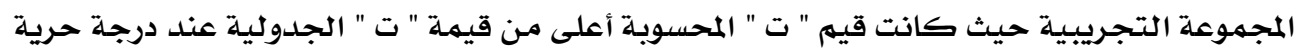

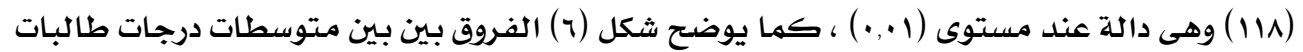

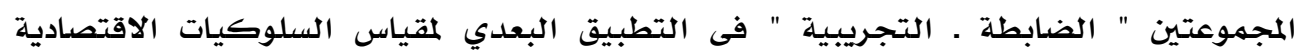

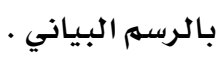

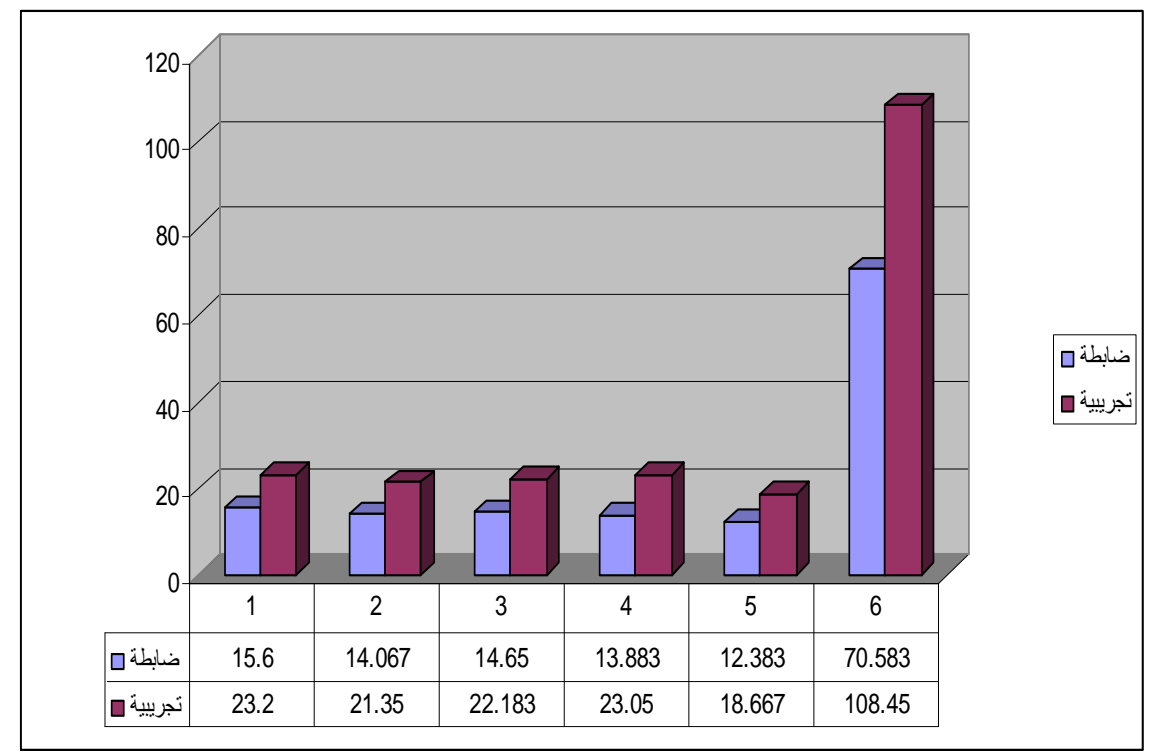

شكل (7)

الفروق بين بين متوسطات درجات طالبات المجموعتين

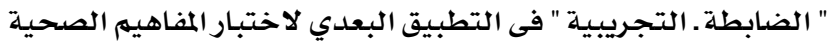

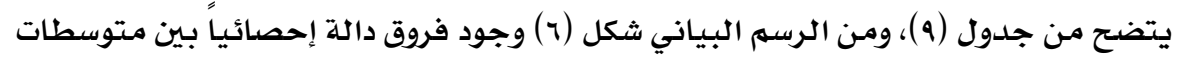

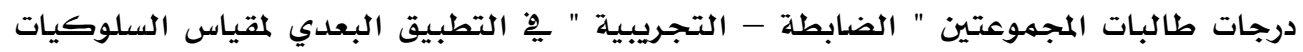

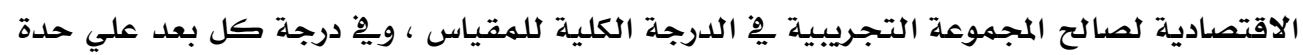

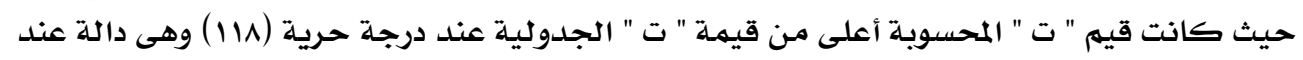

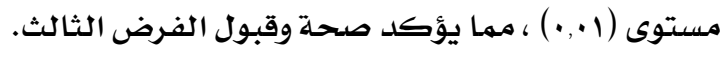

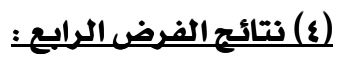

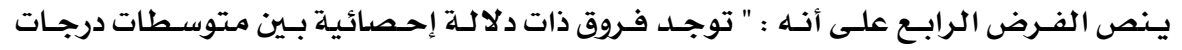

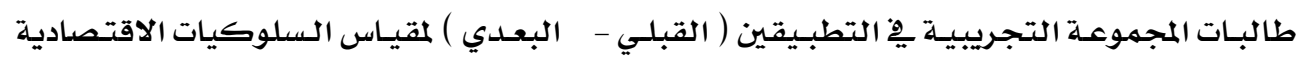
لصايح التطبيق البعدي " . 


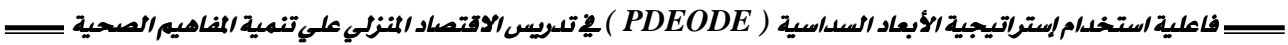

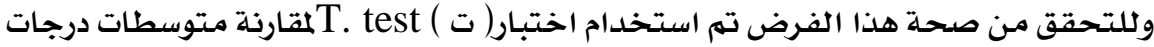

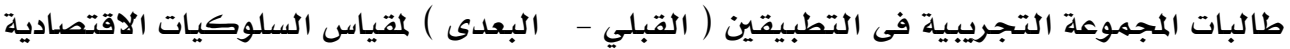

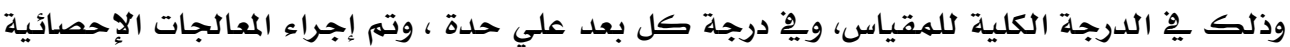

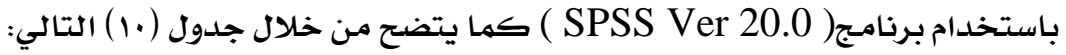

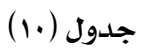

قيمـة " ت " ود لالتها الاحصائية بين متوسطات درجات طالبـات

المجموعة التجريبية في التطبيقين " القبلي - البعدي " لمقياس السلوكيات الاقتصاديـة

\begin{tabular}{|c|c|c|c|c|c|c|}
\hline الدلالة الإحصائية & قيمة (ت) & $(\varepsilon)$ & ( $(\mathbf{P})$ & (j) & التطبيق & أسلوكياد مقياس الاقتتصادية \\
\hline \multirow{2}{*}{ دالة عند ا•,• } & \multirow{2}{*}{ rq, rIq } & $1, \mathrm{VIN}$ & Ir,riv & 7. & القبلي & \multirow[t]{2}{*}{ ترشيد الاستهلاك } \\
\hline & & $1, \cdot \leqslant 0$ & $r \cdot \cdot, r r$ & 7. & البعلى & \\
\hline \multirow{2}{*}{ دالة عند ا+,• } & \multirow{2}{*}{ ra, $\mathrm{MIA}$} & $1,11 \mathrm{~V}$ & 11, ro. & 7. & القبلي & \multirow[t]{2}{*}{ ترشيد الانفاق } \\
\hline & & Y,OAY & $r 0 \cdot, r i$ & 7. & البعدى & \\
\hline \multirow{2}{*}{ دالة عند ا+, • } & \multirow{2}{*}{ rA, ral } & $1,1 \cdot r$ & 1., ro. & 7. & القبلي & \multirow[t]{2}{*}{ فنون الشراء } \\
\hline & & Y,Yרs & MAT,Yr & 7. & البعدى & \\
\hline \multirow{2}{*}{ دالة عند ا+,. } & \multirow{2}{*}{ §o, ^০Y } & $1,0 \wedge \Lambda$ & Ir, 50. & 7. & القبلي & \multirow[t]{2}{*}{ تخطيط الميزانية } \\
\hline & & $\cdot, 901$ & $.0 \cdot, \mathrm{Yr}$ & 7. & البعلى & \\
\hline \multirow{2}{*}{ دالة عند ا•,• } & \multirow{2}{*}{ r•,rฯq } & $1, \cdot 9 \mathrm{~V}$ & $11,1 \wedge r$ & 7. & القبلي & \multirow[t]{2}{*}{ الادخار } \\
\hline & & 1,rA9 & 778,11 & 7. & البعدى & \\
\hline \multirow{2}{*}{ دالة عند ا•,• } & \multirow{2}{*}{$9 r, 901$} & r,ora & 01,901 & 7. & القبلي & \multirow[t]{2}{*}{ الدرجة الكلية } \\
\hline & & \&, ral & $\{0 \cdot, 1 \cdot 1$ & 7. & البعلى & \\
\hline
\end{tabular}

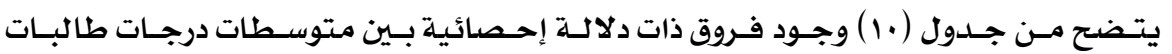

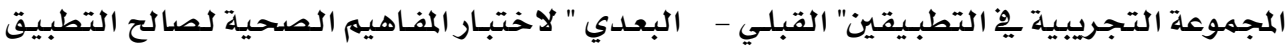

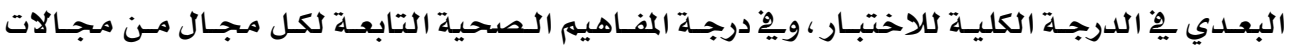
الاقتصاد المنزلي علي حدة ، حيث كانت قيهم " ت " المحسوبـة أعلى من قيمـة " ت " الجدولية عندـ درجـة

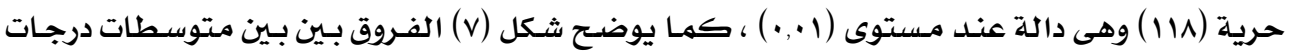

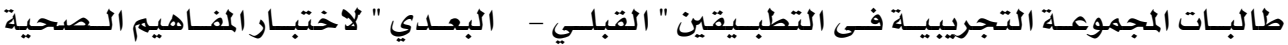
• بالرسهم البياني 


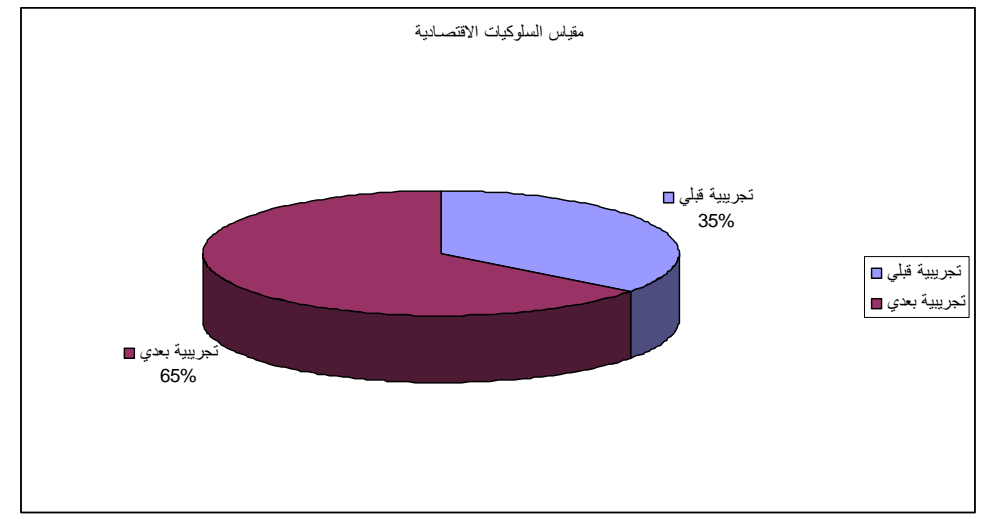

( ) شكل (2)

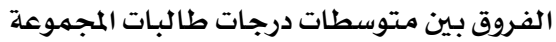

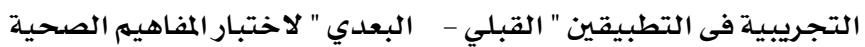

تفسير نتائج الفرضين الثالث والرابي

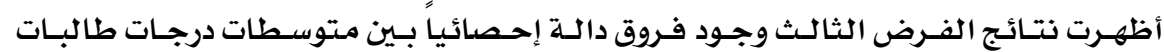

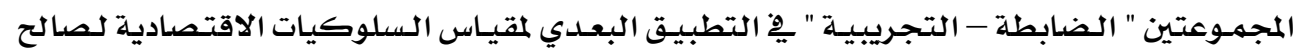

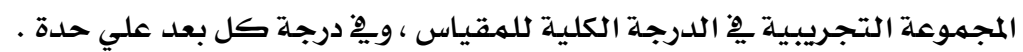

وأظهرت نتائج الفرض الرابع وجود فروق ذات دلالة إحصائية بين متوسطات درجات طالبات

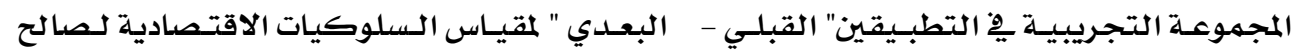

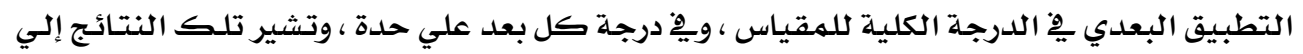

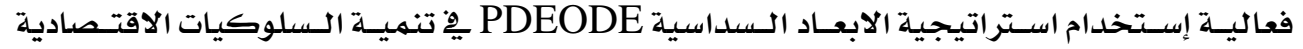

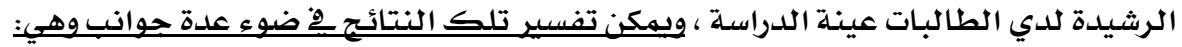

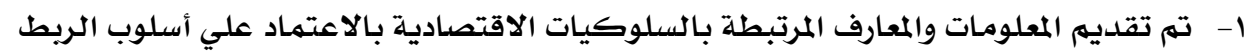

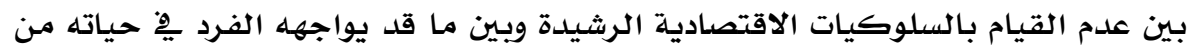

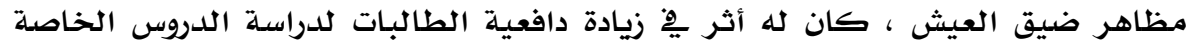

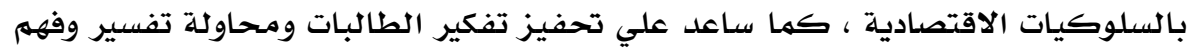

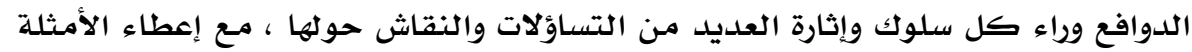

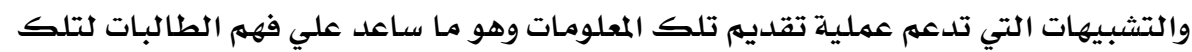

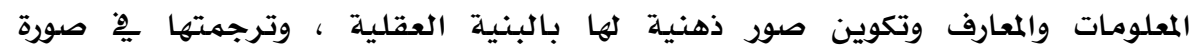
سلوكيات إيجابية . r- وفرت أبعاد استراتيجية PDEODE والمتمثلة ِِّ ( التنبؤ - المناقشة - التفسير - الملاحظة

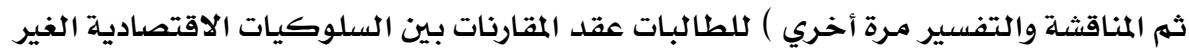

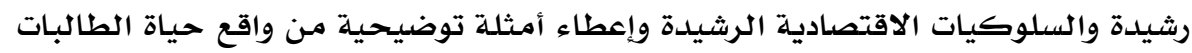




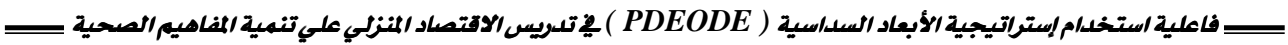

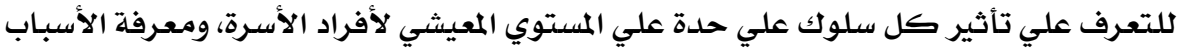

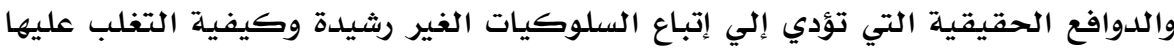

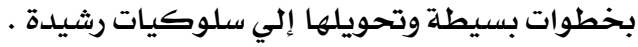

r- ساعدت استراتيجية PDEODE الطالبات علي بذل الجهد العقلي والذهني أثناء البحث

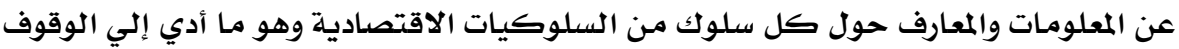

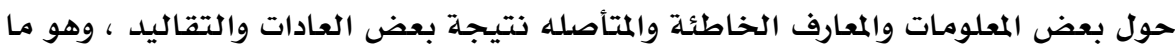

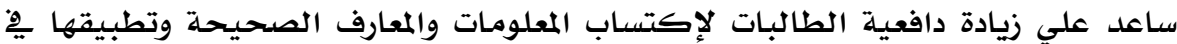

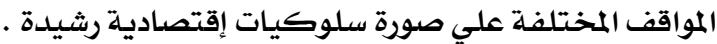

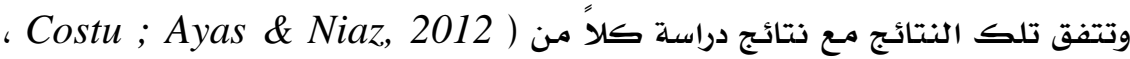

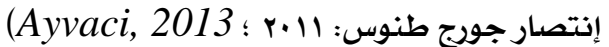

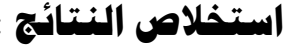

ا- توجد فروق دالة إحصائياً عند مستوي (1...) بين متوسطات درجات طالبات المجموعتين "

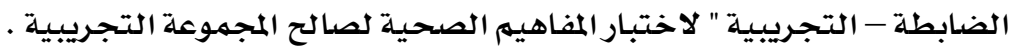

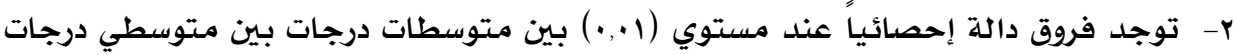

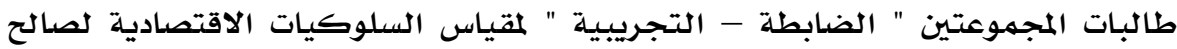
المجموعة التجريبية

\section{توصيات الدراسة :}

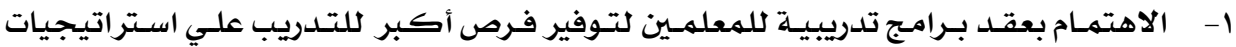

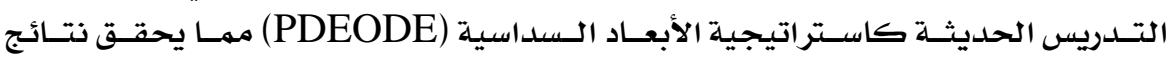
تعلهم أفضل مالتهل r- على معلمات الاقتصاد المنزلي إتقان طرق التدريس الحديثة التي أثبتت الدراسـات والبحـوث

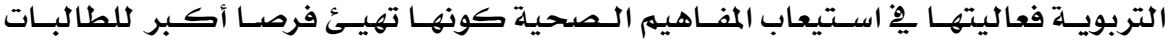

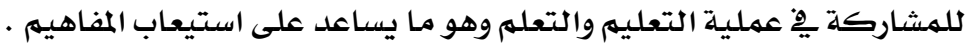

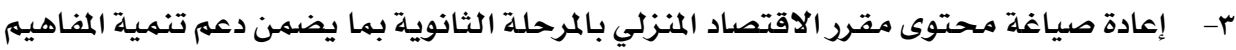

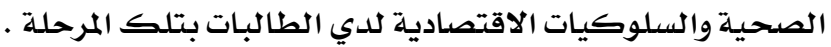

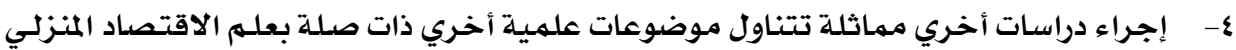
ويْ مـراحل تعليمية مختلفة غير تلك التي أجريت عليها الدراسة الحالية .

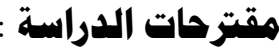

هناك عدة دراسات وبحوث مقترحة يهكن إجراؤها يِّ هذا المجال منها :

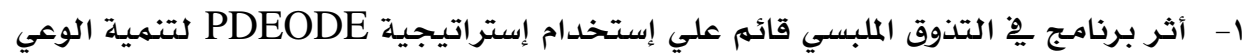

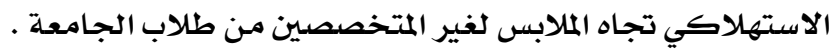


ץ- فعالية برنامـج يج التربية الأسرية لتنميـة المفاهيهم الصحية والسلوكيات الاقتصادية لذوي

الاحتياجات الخاصدة . ألخهات

ץ- أثر برنامـج إرثـادي تثقيفي يخ الاقتصاد المنزلي علي تعزيز قدرة المستهلك علي إختيـار السلع

وكيفية إستخدامها

ع- فعالية وحلدة دراسيـة مقترحة يف الاقتصساد المنزلي قائمسة علي مباديء التربية الصحية لتنمية

التتور الصحي لدي تلاميذ المرحلة الابتدائية .

\section{هراجع الدراسة}

أولاً: المراجع العربية

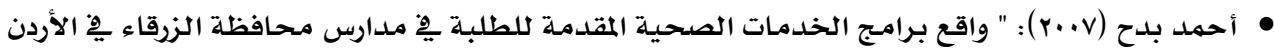
من وجهة نظر مديري المدارس "، مجلة جامعة النجاح لكلأبحاث (العلوم الإنسانية)، فلسطين، اب(Y)، . ras $-r v r$

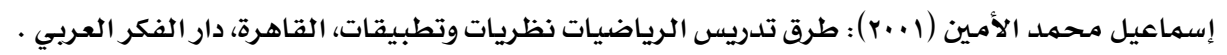
• انتصار جورج طنوس (11 ·r) : أثر استراتيجية تلدريسية ( PDEODE ) قائمة علي المنحي البنائي ِِ فهم

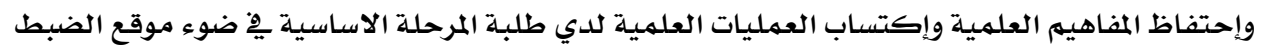
لديهم، رسالة ماجستير، كلية الدراسات العليا، الجامعة الاردنية ، عمان.

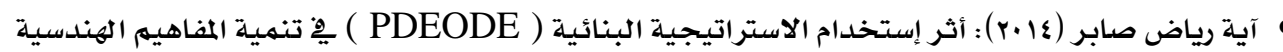
ومهارات التفكير البصري ِِّ الرياضيات لدي طالبات الصف الثامن الأسـاسي بغزة، رسالة ماجستير ، كلية التربية ، الجامعة الاسلاميلة ، غزة .

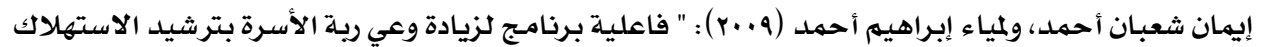
الملبسي "، المؤتمر السنوي ( الدولي الأول - العربي الرابع )الاعتماد الاكاديهي لمؤسسات وبرامج التعليهم العلي النوعي يْ مصر والعالم العربي " الواقع والمأمول "، كلية التربية النوعية ، جامعة المنصورة ، الفترة

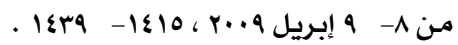

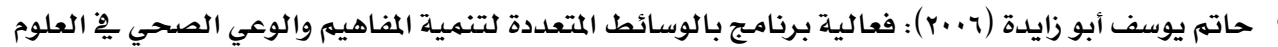
لدي طلبة الصف السـادس الأساسي ، رسالة ماجستير ، كلية التربية ، الجامعة الاسلامية - غزة .

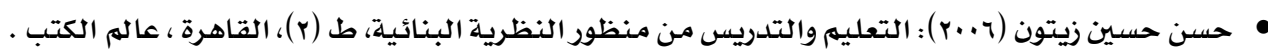
• حلهي أحمد الوكيل ومحمد أمـين المفتي (2007) : أسس بناء المنهج وتنظيماتها، عمان، دار المسيرة

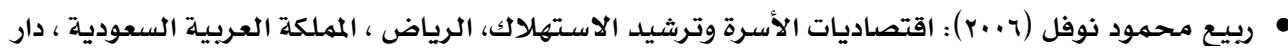

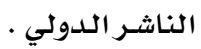

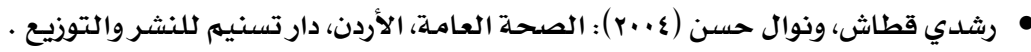

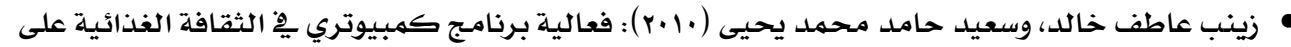
التحصيل المعريِ وتنمية الوعي الغذائي والصحي لدى تلاميذ المرحلة الإعدادية ، مجلة كلية التربية -

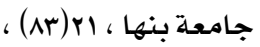




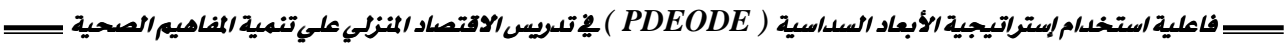

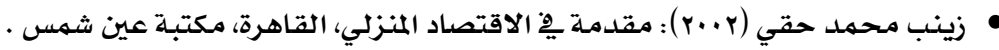

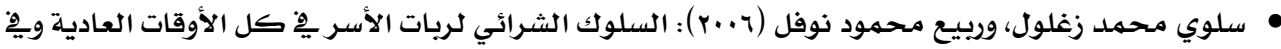
فترة التخفيضات وعلاقته بتوافقهن الشخصي، بحوث المؤتهر العربي العاشر لكلاقتصاد المنزلي ( آفاق

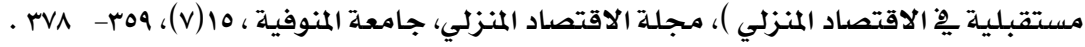

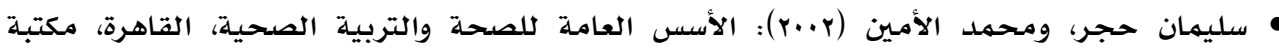
ومطبعة الغد .

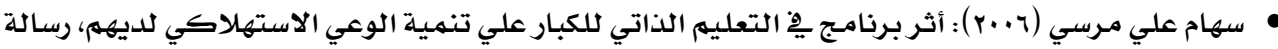

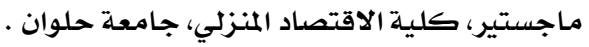
• عبد الحي محمود صالح (r..r): الصحة العامة بين البعدين الإجتماعي والثقايِ ، القاهرة ، دار المعرفة الجامعية .

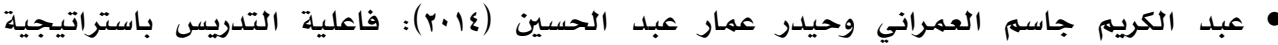
(PDEODE)

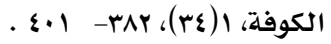
• عبد الوهاب عبد السلام طويلة (r+.r): التربية الاسلامية وفن التدريس ، ط (r) ، القاهرة ، دار عزت عبد الحميد محمد حسن (11 +r) : الاحصاء النفسي والتربوي - تطبيقات بإستخدام برنامـج SPSS 18 • علي حسن الأحمدي (r.r): " مستوى الوعي الصحي لدي تلاميذ الصف لثاني الثانوي وعلاقته باتجاهاتهم الصحية يِّ المدينة المنورة "، رسالة ماجستير، كلية التربية، جامعة أم القري بمكة المكرمة، المملكة العربية السعودية .

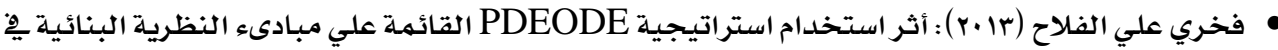
تحصيل طلبـة المرحلة الاساسية الأردنية يِ الكيمياء ويْ تحسين مهارات التفكير التأملي والمهارات الدائية لديهم ، رسالة دكتوراة ، كلية الاداب والدراسات التربوية ، جامعة العلوم الإسلامية العالمية ، فلسطين .

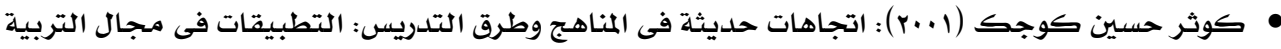

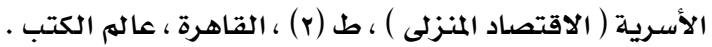

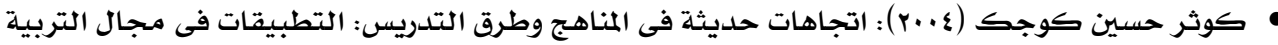
الأسرية ( الاقتصاد المنزلى ) ، ط (r) ، القاهرة ، عالم الكتب .

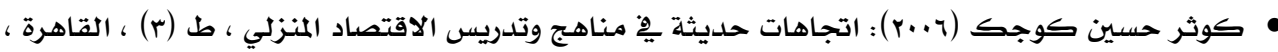

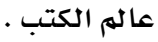

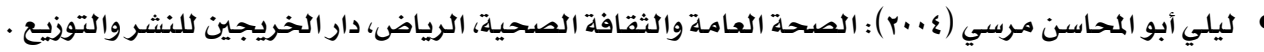

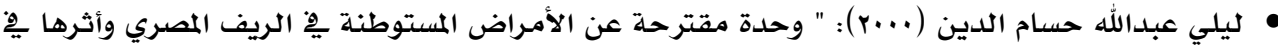
تنمية الوعي الصحي لدي السيدات الريفيات "، مجلة التربية العلمية ، جامعة عين شمس ، ب(1)، . 109 - Irr 


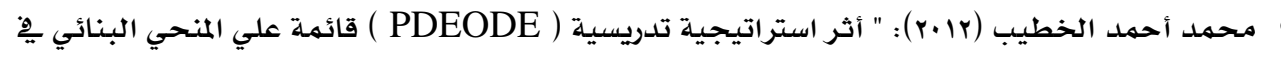

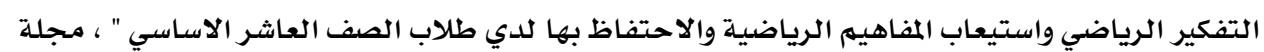

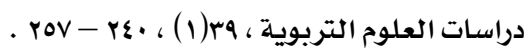

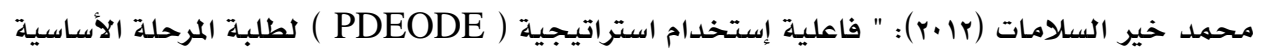

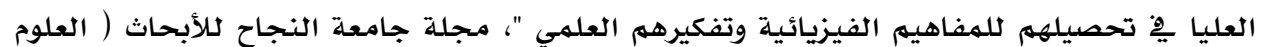

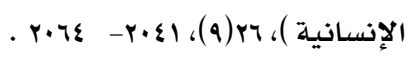

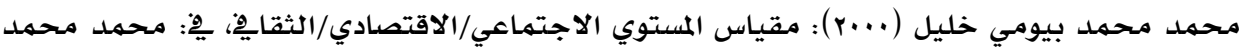

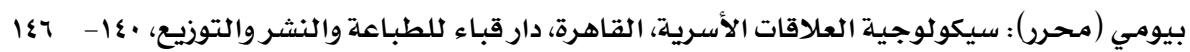

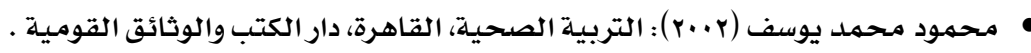

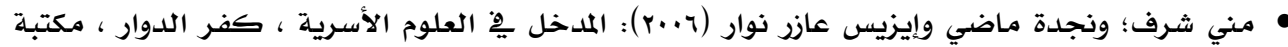
بستان المعرفة .

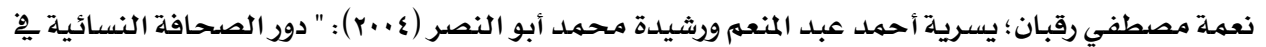

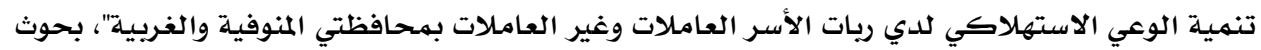

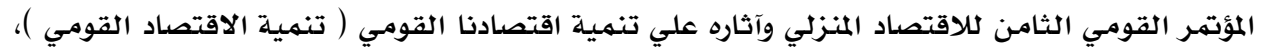

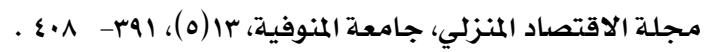

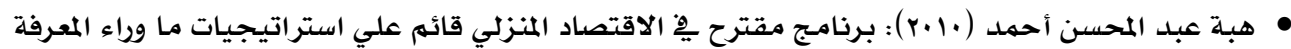
وأثره هِّ تنمية الوعي الاستهلاكي والتفكير الابتكاري لدي طالبات شعبة التعليم الاساسي بكلية التربية

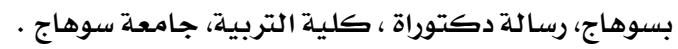

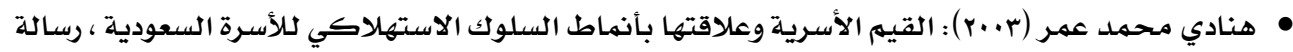

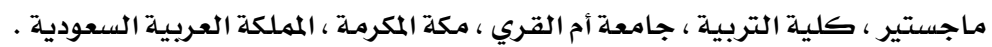

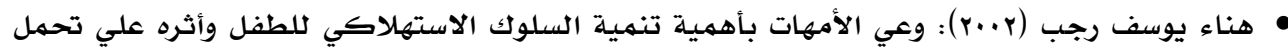

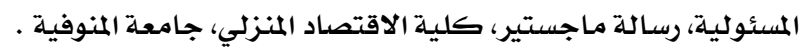

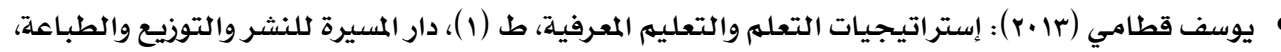
عمان، الأردن .

\section{ثانياً: المراجع الاجنبية}

- Applefield,M.; Huber,R. \& Moallem,M.(2000). Constructivism In Theory And Practice: Toward a Better Understanding. High School Journal. 84(2), 35-53.

- Ayvaci, H. (2013). Investigating The Effectiveness Of Predict- Observ- Explain Strategy On Teaching Photo Electricity Topic. Journal of Baltic Science Education. 12( 5), 548-564.

- Chaney- Cullen, T. \& Duffy, T. (2000) . Strategic teaching framework: Multimedia to support teacher change. The Journal of the Learning Science, 8 (1), $1-40$. 


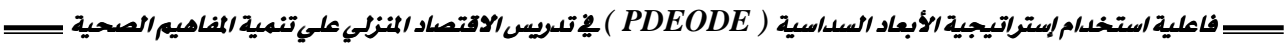

- Costu,B.(20-^). Learning Science through the PDEODE Teaching Strategy: Helping Students Make Sense of Everyday Situations. Eurasia Journal of Mathematics, Science \& Technology Education, 4(1), 3-9.

- Costu,B.;Ayas;A.\&Niaz,M.(2010).Promoting conceptual change in students' understanding of evaporation. Chemistry Education: Research and Practice, 11(3), 5-16.

- Costu, B. ; Ayas, A. \& Niaz, M. (2012). Investigating the effectiveness of a POE-based teaching activity on students' understanding of condensation. Instructional Science Journal. 40, 47-67.

- Fagan, C. (2007). Economics knowledge, attitudes and experience of student teachers in Scotland. citizenship, social and economic education. An International Journal, 7(3). 175-188.

- Gabhainn, N \& Kelleher, C (2000). School Health Education And Gender: An Interactive Effect?. Health Education Research - Theory \& Practice, 15(5), 591-602.

- Hollander, S. (2002). "Providing health information to the general public: A survey of current practices in academic health sciences libraries". Bulletin of the Medical Library Association. 88(1). 62-69

- Hubbard, B. \& Rainey, J. (2007). Health Literacy Instructions and Evaluation among Secondary School Student. American Journal Of Health Education. 38(6), 332-336.

- Hutchings, K. ; Lamberth, S. \& Turpie, J. (2002). Socio-economic characteristicsof gill and beach-seine net fishers in the Western Cape. South Africa . S. Afr. J. mar. Sci. (24), 243-262.

- Jian, L. \& Yungang, L. (2013). Stabilization of coupled pde-ode systems with spatially varying coefficient. Journal Of Systems Science and Complexity, 26(2), 151-174.

- Kolari, S. \& Ranne, S. (2005). Improving Student Learning in an Environmental Engineering Program with a Research Study Project . International journal of engineering Education. 21(4), 702-711.

- Koseoglu, F. \& Kavak, N. (2001). Constructivist approach in science teaching. Journal of Gazi Education Faculty. 2 (1), 139-148. 
- Olsen, D. (2000) . Constructivist principles of learning and teaching methods. Education, 120 (2), 347 - 355.

- Onyango, O. (2005). Changing Concepts Of Health And illness among Children Of Primary School age in Western Kenya, Oxford Journals. 19(3). 326-339.

- Philip, K. (2000). Marketing Management. Prentice- Hall International. London.

- Richardson,V. (2003). ConstructivistPedagogy. Teacher College Record. 105(9), 1623-1640.

- Sahin, T. Y. (2003) . Student teachers' perception of instructional technology: developing materials based on a constructivist approach.British Journal of Educational Technology, 34 (1), 67 - 74.

- Savander, C. and Kolari, S., (2003). Promoting the conceptual understanding of engineering students through visualization. GlobalJournal of Engineering Education, 7(2), 189-199.

- Sholihin, H. (2013). Students' Conceptual Change And Science Process Skills Acquisition On Separation Of Mixture Concept Through Predict-DiscussExplain-Observe-Discuss-Explain (Pdeode) Method. PH.D, Universitas of Pendidikan Indonesia .

- Summerfield, L. (2000). National Standards for School Health Education. Journal of School Health. 63(1), 24-27.

- Tan, S. ; Cheng, P. ; Soon, H. ; Ghazali, H. \& Mahyudin, N. (2013). A qualitative study on personal hygiene knowledge and practices among food handlers at selected primary schools in Klang valley area, Selangor, Malaysia, International Food Research Journal, 20(1), 71-76.

- Walstad, W. \& Rebeck, K. (2001). Assessing the economic knowledge and economic opinions of adults. The Quarterly Review of Economics and Finance, 42, 921-935.

- WHO (2004). Promoting mental health: concepts,emerging evidence, practice: summary report. Geneva, World Health Organization. 


\section{The Effectiveness of Using PDEODE Strategy in Teaching Home Economics For developing Health Concepts and Economic Behaviors among secondary school first-grade students} DR. Ghada M. H. El-Nouby"

\section{Study summary}

The present study aimed at measuring the effect of using PDEODE in teaching home economics on developing some health concepts and economic behavior of female secondary first graders. To achieve this aim, a content analysis of first year secondary school home economics textbook was carried out, an inventory of health concepts and needed economic behavior was developed based on the PDEODE strategy.

The sample of the study consisted of 150 female secondary first graders, divided into two groups; a control in Fatma Al Zahraa secondary school and an experimental in Sayyeda Zeinab secondary school. Tools of the study included: a test in health concepts and a scale for economic behavior (both developed by the researcher).

Results showed the following:

1. There are statistically significant mean differences at 0.01 level between the scores of the two groups in the test of health concepts favoring the scores of the experimental group.

2. There are statistically significant mean differences at 0.01 level between the scores of the two groups in scale of economic behavior favoring the scores of the experimental group.

In the light of these results, a number of recommendations and suggestions were presented.

Keywords: PDEODE Teaching Strategy - Healthey Concepts - Economic Behaviors 